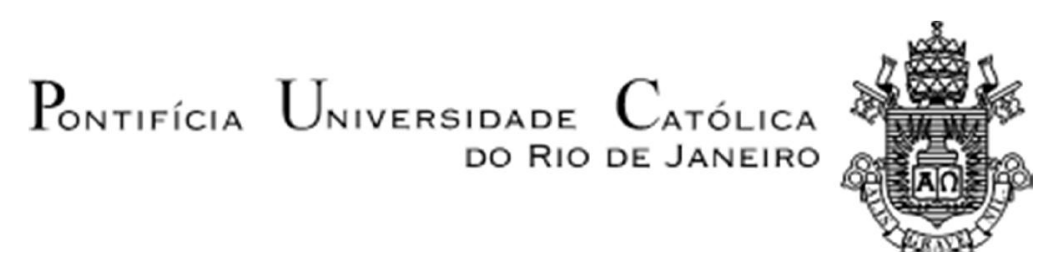

Eduardo Miranda Silva

O campo minado da representação do outro no cinema brasileiro contemporâneo

\begin{abstract}
Tese de Doutorado
Tese apresentada ao Programa de Pósgraduação em Letras da PUC-Rio como requisito parcial para obtenção do título de Doutor em Literatura, Cultura e Contemporaneidade do Departamento de Letras da PUC-Rio.
\end{abstract}

Orientador: Profa ${ }^{a}$ Vera Lúcia Follain de Figueiredo

Rio de Janeiro Maio de 2015 
Pontifícia Universidade Católica

Eduardo Miranda Silva

\section{O campo minado da representação do outro no cinema brasileiro contemporâneo}

Defesa de Tese apresentada como requisito parcial para obtenção do grau de Doutor pelo Programa de Pós-Graduação em Literatura, Cultura e Contemporaneidade do Departamento de Letras do Centro de Teologia e Ciências Humanas da PUC-Rio. Aprovada pela Comissão Examinadora abaixo assinada.

Profa. Vera Lúcia Follain de Figueiredo
Orientadora
Departamento de Letras - PUC-Rio

Prof. Renato Cordeiro Gomes Departamento de Letras - PUC-Rio

Prof. Sergio Luiz Ribeiro Mota - Sergio Mota

Departamento de Letras - PUC-Rio

Profa. Giovanna Ferreira Dealtry UERJ

Prof. Paulo Roberto Tonani do Patrocínio UFRJ

Profa. Denise Berruezo Portinari Coordenadora Setorial do Centro de Teologia e Ciências Humanas - PUC-Rio

Rio de Janeiro, 15 de maio de 2015. 
Todos os direitos reservados. É proibida a reprodução total ou parcial do trabalho sem autorização expressa do autor, da orientadora e da universidade.

\section{Eduardo Miranda Silva}

Graduou-se em Comunicação Social, com habilitação em Jornalismo, pela Pontifícia Universidade Católica do Rio de Janeiro, em 2006. Obteve o título de mestre em Comunicação Social, com área de concentração em Cultura de Massas Representações e Práticas Sociais, também pela PUC-Rio, em 2009. Em 2010, ingressou no Doutorado, no Departamento de Letras da mesma Universidade.

Ficha Catalográfica

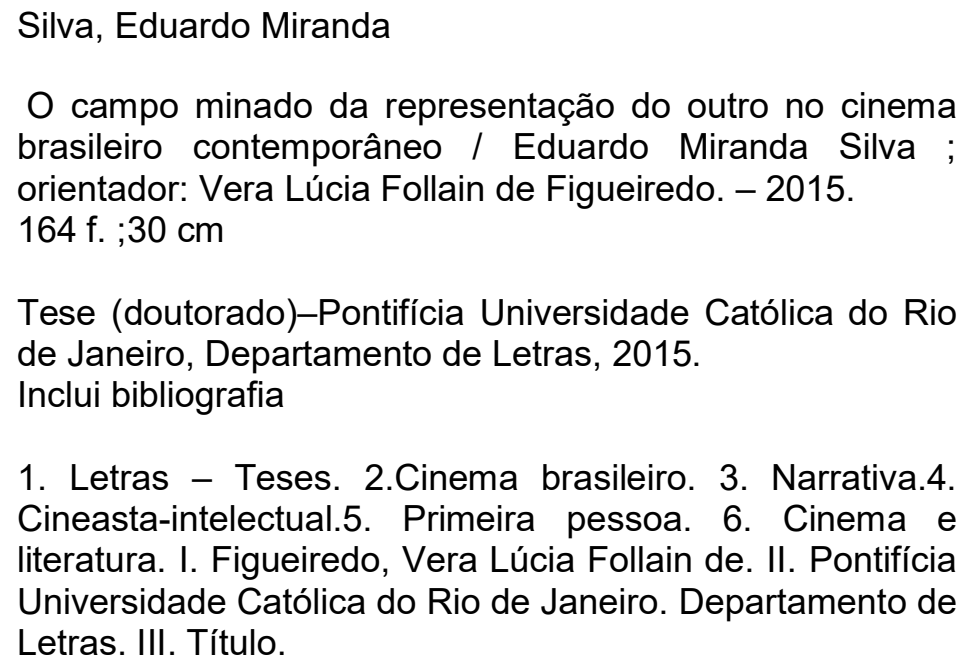
brasileiro contemporâneo / Eduardo Miranda Silva ; orientador: Vera Lúcia Follain de Figueiredo. - 2015.

1. Letras - Teses. 2.Cinema brasileiro. 3. Narrativa.4. Cineasta-intelectual.5. Primeira pessoa. 6. Cinema e literatura. I. Figueiredo, Vera Lúcia Follain de. II. Pontifícia Universidade Católica do Rio de Janeiro. Departamento de Letras. III. Título.

CDD: 800 
Para meus pais, para Vera, Aline e Sael 


\section{Agradecimentos}

À Vera Follain de Figueiredo: não haveria esse percurso sem sua presença. Grande mestre desde a Iniciação Científica, acompanhou minha trajetória, sempre muito generosa e carinhosa em todas as nossas conversas. Seus ensinamentos, que rompem os muros da academia, levarei para o resto da vida.

Aos meus pais, Oswaldo e Lauriene, pelo apoio, pelo incentivo e pelo amor incomensuráveis, e à minha irmã, Viviane Miranda.

Ao Sael Sánchez, que acompanhou de perto todo o processo, me incentivou quando esmoreci e não mediu esforços para ajudar, e à querida Aline Novaes, a quem considero como uma irmã e com quem partilho alegrias e angústias desde o primeiro dia da graduação na PUC-Rio. Essa tese não existiria sem o apoio dela.

Aos amigos Marcia Paterman e Philippe Ladvocat, hoje distantes geograficamente, mas sempre presentes no meu coração, e Luiz Filipe Carvalho, sempre de prontidão para ajudar.

Aos professores Renato Cordeiro Gomes e Giovanna Dealtry, pelos ensinamentos, pela amizade e por aceitarem o convite para integrar a banca de defesa de tese.

Aos professores Sergio Mota e Beto Tonani por aceitarem o convite para participar da banca. Ao Beto devo, ainda, as sugestões compartilhadas no exame de qualificação e o título da tese.

A todos os professores que marcaram minha vida. Ana Paula Pujol, sobretudo.

Aos editores e colegas do jornal Brasil Econômico, pelo apoio e compreensão prestados no processo de escrita da tese.

À Daniele de Oliveira Cruz, secretária do programa de pós-graduação do departamento de Letras, sempre solícita para atender às minhas dúvidas.

À PUC-Rio e ao Departamento de Letras, pelo apoio institucional fundamental para a conclusão dessa pesquisa. 


\section{Resumo}

Silva, Eduardo Miranda; Figueiredo, Vera Lúcia Follain de (Orientadora). O campo minado da representação do outro no cinema brasileiro contemporâneo. Rio de Janeiro, 2015. 164p. Tese de Doutorado Departamento de Letras, Pontifícia Universidade Católica do Rio de Janeiro.

Esta tese volta-se para a problematização do papel do cineasta como tradutor de demandas sociais no cinema brasileiro contemporâneo, tendo em vista o que se convencionou chamar, a partir dos anos de 1970, de "virada antropológica" da narrativa cinematográfica. Investiga-se a construção da narrativa em primeira pessoa na ficção do cinema brasileiro pós Retomada, levando em conta a crítica que se fez à "voz do saber" e ao uso da terceira pessoa, predominantes no discurso do Cinema Novo: isto é, num período em que as artes caminhavam em consonância com um projeto coletivo e igualitário de nação. No intuito de refletir sobre a relação entre opções estéticas e políticas no que diz respeito às práticas de enunciação, a tese privilegiou filmes baseados em obras literárias que suscitam o questionamento do lugar de fala do narrador ( $A$ Hora da estrela, Abril despedaçado e Cidade de Deus) e pares de filmes a partir dos quais se pode caracterizar o movimento pendular da produção contemporânea entre o cineasta-intelectual que arroga para si o papel de falar sobre e pelo outro e o cineasta-etnógrafo que cede espaço para a fala do outro de classe. Os pares Tropa de elite e Notícias de uma guerra particular, Carandiru e $O$ Prisioneiro da grade de ferro e, por último, Cinco vezes favela e $5 X$ favela - Agora por nós mesmos foram analisados à luz das questões levantadas.

\section{Palavras-chave}

Cinema brasileiro; narrativa; cineasta-intelectual; primeira pessoa; cinema e literatura. 


\section{Abstract}

Silva, Eduardo Miranda; Figueiredo, Vera Lúcia Follain de (Advisor). The minefield of representation of the Other in contemporary Brazilian cinema. Rio de Janeiro, 2015. 164p. Departamento de Letras, Pontifícia Universidade Católica do Rio de Janeiro.

The thesis turned its attention to questioning the role of the filmmaker as a translator of social demands in contemporary Brazilian cinema, specifically 1970's "anthropological approach" of narrative film. The work investigates the construction of the first-person narrative in Brazilian cinema after the so-called Retomada, taking into account the criticism of the "voice of God" and the use of the third person, which are predominant in the speech of the Brazilian movement Cinema Novo: That is, a period in which the arts were in line with a collective and egalitarian notion of nation. In order to discuss the relationship between aesthetic approaches and policies with regard to the statement of these practices, the thesis focused on films based on literary works that raise the question of the place of the narrator (Hour of the Star, Behind the Sun and City of God) and pairs of films from which one can characterize the pendulum of contemporary production between the filmmaker-intellectual who apropriate to themselves the role of talking about and for each other, and the filmmaker-ethnographer, that provides room for the speech of another class. The films Elite Squad and News From a Personal War, Carandiru and Prisioneiro da grade de ferro, and finally Cinco vezes favela and $5 X$ Favela - Now by Ourselves were analyzed in the light of the issues raised.

\section{Keywords}

Brazilian cinema; narrative; filmmaker-intellectual; first person; cinema and literature. 


\section{Sumário}

1. Introdução

2. O cineasta como intelectual dos anos 60

2.1. Projeto utópico no cinema brasileiro moderno 25

2.2. Intelectuais no filme e fora deles 30

2.3. O golpe militar e a crise da representação 40

2.4. Da sobrevivência do intelectual à virada antropológica 47

3. A política da voz do outro 51

3.1. Impasses do falar pelo outro no documentário brasileiro moderno

3.2. A utopia do cinema direto: para acabar com o julgamento [da voz] de Deus

3.3. Eduardo Coutinho: um discurso sobre o método

3.4. Entre os excessos do direto e da entrevista, o recuo da voz do diretor

4. Do livro ao filme, os desdobramentos dos narradores

4.1. Respostas da ficção às demandas sobre a voz e a reflexividade

4.2. Realismo, anti-ilusionismo e metalinguagem em A Hora da estrela

4.3. O ocaso da autorreflexividade na adaptação de Abril Despedaçado

4.4. Pelas mãos seguras de Buscapé: deslizamento de classes em Cidade de Deus

5. As vozes de legitimidade entre o documentário e a ficção Elite 
5.3. Negociação das vozes em $5 X$ favela - agora por nós mesmos

6. Conclusão

153

7. Referências bibliográficas 
“O próximo é promessa, não é uma ameaça. Temos que recuperar a visão do próximo, a partir dos valores escondidos nos corações das pessoas incultas. Culto é aquele capaz de ver o outro. Sozinhos, nada faremos."

Eduardo Galeano

"E haveria sempre alguém que pudesse narrar isso por ele, até que as condições socioeconômicoculturais da classe operária se transformassem no país e ela pudesse falar com a própria voz."

Sérgio Sant'Anna, Um discurso sobre o método 


\section{Introdução}

A expressão "Cinema da Retomada", que designa a produção cinematográfica brasileira a partir dos anos 90 denota o momento em que o número de filmes lançados anualmente aumenta e se estabiliza, depois de um período difícil, com a extinção da Embrafilme, estatal produtora e distribuidora, no governo de Fernando Collor. O vocábulo "retomada" guarda, por este ângulo, o reatamento dos laços do cinema com a mídia televisiva (na produção, na divulgação e na difusão), de modo que esta reabilita e, por conseguinte, amplia o público do cinema brasileiro. Em outro viés, a "retomada" expressaria a recorrência, no cinema brasileiro de ficção, da figura do personagem excluído das benesses do capitalismo de consumo, autoexilado do espaço territorial e sociocultural de origem e marginalizado nos grandes centros urbanos. Ou seja, esse cinema retornaria aos temas do Cinema Novo - sertões e favelas. No entanto, essa filiação do cinema contemporâneo ao cinema moderno brasileiro não foi unanimemente aceita. A metáfora da morte do pai aparece tematizada não apenas nos filmes, mas também nos próprios mecanismos de produção. O pai - Cinema Novo - retorna como mal-estar quando a crítica de tradição moderna olha para a produção atual à luz do cinema moderno. Por outro lado, a recepção crítica, ao cobrar da produção mais recente o mesmo tipo de perspectiva do cinema canonizado, tomando-o, portanto, como referência de leitura da sociedade, legitima essa filiação.

Porém, o que difere o cinema contemporâneo de seu pai moderno e que torna mais complexa a ideia de uma retomada é a constatação de que os modos de pensar a sociedade foram radicalmente alterados. Atualmente, é pequeno o espaço para o cineasta intelectual de outrora, engajado em causas sociais e preocupado em levar ao povo a mensagem de uma iminente revolução que vinha sendo planejada pelas esquerdas. A impossibilidade de engajamento, tal como se deu no Cinema Novo, tem suas causas na decepção gerada pelos rumos de regimes de esquerda e pela consolidação da ética individualista e pragmática do capitalismo tardio. A ausência de projetos coletivos e de um cineasta com papel de guia da sociedade têm reflexos nos filmes. Lúcia Nagib, em seu livro A utopia no cinema 
brasileiro, aborda o tratamento dado, em diversos filmes da retomada, ao deslocamento geográfico. Esses filmes, em consonância com o sentido literal do termo utopia, narram trajetórias de personagens que, embora busquem um espaço topográfico onde o homem poderia se realizar, um eldorado, são tomados pela desesperança, ou, então, já admitem de antemão o malogro do projeto coletivo de revolução, vislumbrado pelo cinema utópico dos anos 60 .

O eixo dessa tese tangencia também a questão da utopia, mas analisando o modo como a voz é utilizada nas décadas de 1960, 1970 até o momento atual. Os focos aqui recaem sobre o narrador intradiegético autorreflexivo, geralmente personificado em um escritor ou jornalista que reconhece, no interior do próprio universo ficcional, as dificuldades de se falar sobre o outro, e sobre o emprego da primeira pessoa no discurso do filme e suas implicações no discurso do diretor/realizador. Sabemos que, nos anos 1960, na maioria das narrativas cinematográficas ficcionais, o personagem-narrador tinha seu discurso colado ao do diretor. No cinema de Glauber Rocha, expoente do Cinema Novo, Antônio das Mortes, de Deus e o diabo na terra do sol, e Paulo Martins, de Terra em transe, representavam o pensamento do próprio diretor. Também no cinemadocumentário, a voz proferida em off era a voz do diretor e a visão que o espectador compartilhava era a visão desse diretor sobre o mundo. A partir de meados dos anos 60, com o golpe militar, os intelectuais fizeram uma autocrítica para entender o porquê da derrota das esquerdas. Colocava-se em xeque, sobretudo, a ideia de "povo", tão cara ao Cinema Novo e ao CPC da UNE, em face da constatação de que este povo não havia sido conscientizado. Imaginava-se, até então, que o intelectual tinha o mandato de conscientização e o povo seria o agente transformador e revolucionário. O povo não fez a revolução, como também não resistiu ao golpe militar.

Junto à autocrítica do cineasta, acrescente-se a chegada do cinema direto no Brasil. O cinema direto possibilitou que câmeras de menor porte pudessem captar imagem e som simultaneamente. Portanto, se antes era a voz do cineasta a voz que sobressaía no filme (na ficção e no documentário, essas vozes, como narração em off ou pronunciadas em diálogo de personagens, eram gravadas em estúdio), com a chegada do cinema direto, a captação permitiu que o cinema pudesse ouvir a dicção das ruas, a voz do outro. Ao mesmo tempo em que se avolumava a crítica à voz do saber e da autoridade, à voz de quem não ouvia o 
outro, o cinema documentário ganhava a tecnologia que permitiria captar o que esse outro tinha a dizer. Como tais mudanças se fizeram sentir com mais ênfase no documentário e o foco da crítica, à época, concentrou-se nele, levamos em conta esse dado para traçar o trajeto da tese. Ademais, o direto não teve repercussão imediata no cinema de ficção no que se refere a uma narrativa que se descolasse do discurso do cineasta. Melhor dizendo, o cinema direto se aplicou nas tomadas de câmera da ficção, mas o discurso do diretor ainda se fez ouvir na narrativa. É, pois, no documentário que a demanda de transferência da voz se faz mais urgente, visto que será cobrada do diretor uma nova postura, voltada para dar voz àqueles que pouco ou quase nunca se pronunciaram e quase nunca foram consultados.

Considerando o recuo utópico no cinema da retomada, voltamos, então, nosso foco para o cinema de ficção que privilegia as narrativas em primeira pessoa. É nesse cinema que se dará o conflito ético e ideológico entre o discurso do personagem-narrador e o discurso do diretor/roteirista do filme. Alguns críticos, como Cléber Eduardo, levantam a hipótese de que, em alguns momentos, o cineasta quer esconder o seu discurso nas palavras do personagem. Isto revelaria, portanto, uma terceira pessoa disfarçada em primeira. É o exemplo de Cronicamente inviável (2000), de Sérgio Bianchi, como aponta o próprio crítico. Essa hipótese de um cômodo encobrimento do ponto de vista do cineasta servirá de ponto de partida para a análise de Carandiru (2003), contemplado no corpus do presente trabalho. Já em Tropa de Elite (2007), pretendemos verificar o processo de construção de um personagem-narrador que, em princípio, divergiria radicalmente de seu diretor, provocando uma cisão com a classe média, cuja imagem vinha sendo resguardada, no cinema das últimas décadas, de representações mais contundentemente críticas, no que diz respeito às suas responsabilidades sociais. Em $5 X$ favela - agora por nós mesmos (2010), que encerra o último capítulo da tese, nos interessa refletir sobre a autocrítica do cineasta Cacá Diegues, que o impele à revisão de seu olhar sobre o oprimido, agora excluído, e o coloca como coordenador de uma produção na qual a voz será emitida pelos próprios moradores das favelas.

Em paralelo à questão da primeira pessoa, discutiremos, também, algumas adaptações que têm como texto-base obras literárias. O objetivo é não tanto discutir questões da narrativa literária, mas partir dela para entender a fatura, a 
diegese e os processos extra-fílmicos de Abril despedaçado (2001), A Hora da estrela (1985) e Cidade de Deus (2002). Os romances que deram origem aos dois primeiros filmes trabalham a crítica ao poder de narrar da classe média dentro do próprio enredo. Interessa-nos compreender que motivos e justificativas levaram os cineastas Walter Salles e Suzana Amaral a retirarem de seus filmes a narração autorreflexiva. Com Cidade de Deus, indagamo-nos sobre que fatores levaram o diretor Fernando Meirelles a ampliar a representação do narrador Buscapé, um personagem que transita com facilidade na favela, entre seus pares, e nas camadas sociais mais abastadas. De antemão, indagamos até que ponto Buscapé, narrador intradiegético, legitima o discurso fílmico e, por conseguinte, a entrada de Meirelles na Cidade de Deus. Já Salles e Amaral estariam adiando em seus filmes a entrada da autocrítica, nostálgicos de um cinema do passado que ousou falar pelo outro e do papel do cineasta como tradutor das demandas sociais?

Para tanto, privilegiaremos, no primeiro capítulo da tese, o debate acerca da acepção moderna do intelectual a partir do polêmico caso Dreyfus, que data do final do século XIX. O intuito é chegar à questão do engajamento, tal qual propôs Jean-Paul Sartre em sua defesa dos intelectuais, definindo este como "alguém que se mete no que não é de sua conta e que pretende contestar o conjunto das verdades recebidas (...) em nome de uma concepção global do homem e da sociedade". Em sentido oposto e mais próximo do momento atual, temos Pierre Bourdieu questionando a pretensão intelectual à luz do que chamou de "dominação simbólica" e Michel Foucault, em seu Microfísica do poder, operando um deslocamento do lugar de representante para o de questionador dessa representação, contra a "indignidade de falar pelos outros". Nosso corte histórico no que diz respeito à produção cultural brasileira inicia-se no contexto do CPC, do Teatro de Arena e do Cinema Novo. Este último, representado, sobretudo, na figura de Glauber Rocha, que cunhou na teoria e na prática a "estética da fome", buscando inspiração no engajamento artístico já observado na escrita da literatura de 1930. É isso o que leva o cineasta Nelson Pereira dos Santos a afirmar que Vidas Secas, de Graciliano Ramos, constitui já para ele um roteiro de cinema em si.

Os "tradutores de demandas sociais", no entanto, têm seus projetos minados com o golpe militar em 1964. Outro golpe, desferido desta vez pela crítica cinematográfica, aponta o tom paternalista dos intelectuais de classe média 
na leitura que se fez do "povo". Jean-Claude Bernardet, um dos críticos mais contundentes do movimento, afirma que as preocupações dos cineastas revelariam, no seu subtexto, o desejo de manutenção da aliança entre classes; as manifestações em torno dos filmes "não eram realmente questões de dramaturgia, mas antes manifestações de uma atitude paternalista cuja finalidade é controlar a massa".

A perda da utopia e das ilusões dos produtores culturais/intelectuais conjuga-se num espectro maior à revisão crítica das esquerdas no mundo. Tal movimento levará Norberto Bobbio a destacar a substituição de um intelectual utopista, que queria mudar o mundo, por um intelectual realista, afirmando que "caiu em descrédito o intelectual utopista que gostaria de mudar o mundo à sua imagem e semelhança". As mudanças em escala mundial (a razão iluminista abalada desde a Guerra Mundial, o recuo do socialismo e do pensamento marxista, a ascensão das sociedades pós-coloniais e dos estudos culturais) foram sendo conjugadas pelo discurso nacionalista, endossado por cineastas brasileiros e agora afetados pela ditadura militar e pela decepção dos intelectuais com o povo (que não fez a revolução, como se esperava). Junte-se a isso o desuso da chamada "voz de deus" nos documentários, a partir da chegada do som direto. Nesse sentido, o documentário Cabra marcado para morrer, de Eduardo Coutinho, constitui-se como exemplo paradigmático dessa mudança de método. Realizado num intervalo de 20 anos (entre 1964 e 1984), a visada esquerdista e iluminista do diretor no início do filme recua e cede espaço a uma abordagem antropológica de seus personagens.

Tendo como gancho a estética do documentário de entrevista, o capítulo seguinte abordará o cinema à luz da "virada antropológica", que fez ascender novas vozes do discurso. Como afirmou Beatriz Sarlo, em Tempo passado, as estruturas cederam lugar aos indivíduos. Baseado nisso, buscamos compreender não apenas a queda das estruturas, dos questionamentos dos poderes institucionalizados, mas, simultaneamente, entender que vozes seriam essas que assumiram, no âmbito intradiegético do documentário e da ficção, um discurso periférico sem rédeas, sem a mediação do intelectual de classe média e da narração burguesa da terceira pessoa. Essa mudança metodológica no cinema tem como desdobramento o recuo do cineasta e, por conseguinte, seu papel de guia. Fernão Pessoa Ramos denominou esse movimento crepuscular do cineasta como 
intelectual de "ética modesta", resultando em filmes cuja voz do diretor está escondida e abafada pelo excesso de entrevistas ou deslocada para o discurso de algum personagem.

No cinema de ficção, objeto dos capítulos 4 e 5, optamos, primeiro, por promover um "confronto" de três filmes com seus textos de origem (Abril despedaçado, A Hora da estrela e Cidade de Deus e os romances homônimos de Ismail Kadaré, Clarice Lispector e Paulo Lins, respectivamente) e, em seguida, cotejar outras três ficções (Tropa de elite, Carandiru e $5 X$ favela - agora por nós mesmos) com produções que servem como "provocação" ou resposta (Notícias de uma guerra particular, O Prisioneiro da grade de ferro: autorretratos e Cinco vezes favela, respectivamente) aos filmes analisados no corpus da tese.

Nos filmes Abril despedaçado e A Hora da estrela, a crítica contundente ao papel do intelectual como representante, bastante ressaltada por Glauber Rocha em Terra em transe, desaparece, dando lugar ao outro do cinema brasileiro para manter em situação confortável o narrador do extra-filme, o diretor burguês. Guilherme Sarmiento, num ensaio cabal, defende que esse tipo de filme de abordagem do outro responde menos a um anseio do diretor pela tomada de posição política e social e mais aos imperativos do mercado cinematográfico. Ainda segundo o crítico, "certa resistência ao 'enquadramento' do intelectual responde por uma opção ideológica muito clara, ligada a um projeto conservador de cultura que alguns filmes realizados durante os dez anos que se seguiram à retomada espelham de maneira exemplar." (Sarmiento, 2005: 81). Já a partir do filme Cidade de Deus, em cotejo com o romance de Paulo Lins, voltaremos à questão sobre o falar pelo outro. Neste caso, a discussão não se dará em torno da autoreflexividade. A questão gira em torno do novo realismo proporcionado por esse tipo de narrativa, cuja proximidade se dá por uma narração menos totalizante e mais particularizada, visto que o olhar de terceira pessoa havia sido eliminado para ceder lugar a uma voz corporificada, encarnada num personagem gerador de empatia e identificação com o público.

Por fim, a partir das demais produções, voltamos à questão do "quem pode narrar?", do grau de presença do narrador e da primeira pessoa. Tropa de Elite e Carandiru serão confrontados com documentários. Num primeiro momento, a discussão se dará em torno da contaminação da ficção pelo documentário, no sentido das técnicas absorvidas por este último e da consequente mudança da 
metodologia. Em Notícias de uma guerra particular, mais uma incursão na periferia da capital fluminense, temos, mediando o contato entre o espectador e o mundo do crime, a figura do Capitão Pimentel, embrião do Capitão Nascimento da ficção de José Padilha. Sintomático desse elo entre ficção e documentário, o desabafo do policial fictício começa onde termina o discurso do policial real e seu intuito de deixar o Bope. Ainda na esteira do sucesso de Tropa de Elite, Notícias foi comercializado por ambulantes como Tropa de Elite 2. A relação no sentido contrário (da ficção ao documentário) se dá entre Carandiru e OPrisioneiro da grade de ferro: autorretratos.

Cabe ressaltar a gênese da ficção de Hector Babenco no livro Estação Carandiru, do médico Dráuzio Varella. A obra narra o trabalho do doutor Dráuzio, como o médico ficou popularmente conhecido após o lançamento do filme, entre os presidiários da penitenciária de São Paulo. Nossa análise, no entanto, visa problematizar a relação entre a ficção e o documentário de Paulo Sacramento, cujo complemento "autorretratos" tenta marcar diferença em relação à ficção de Babenco. Assim, o intuito é o de se colocar como um filme em que os próprios detentos poderão narrar suas histórias, ao passo que tínhamos em Carandiru a mediação segura do Doutor Dráuzio, sua incursão e a moldura de seu parecer sobre os habitantes do presídio. Tão assertivo no subtítulo quanto $O$ Prisioneiro da grade de ferro: autorretratos, $5 X$ vezes favela - agora por nós mesmos é a revisão do clássico do Cinema Novo apontado desde a época como um filme de visão esquemática acerca de quem está à margem. As presenças de Cacá Diegues, diretor de um dos episódios da primeira versão, como captador de recursos e coordenador do novo projeto, e da Globo Filmes, como coprodutora, tornam-se pontos críticos do remake. Aqui, nosso debate contemplará problemas relativos à estética domesticada e canonizada por um cinema que não busca nenhum tipo de ruptura. Vale lembrar a quase onipresença das favelas nas telenovelas de uma das maiores emissoras do mundo e que detêm jornais, cadeias de rádio e portais de internet, além de atuar com peso considerável na produção cinematográfica nacional.

À luz das questões levantadas a partir dos romances e das produções audiovisuais, o intuito do trabalho é o de discutir as opções estéticas e políticas em relação ao grau de inserção da narração autorreflexiva e a legitimidade do chamado novo realismo, materializado em depoimentos de vozes periféricas, no 
caso do cinedocumentário, e na estratégia da narração em primeira pessoa, no caso dos filmes de ficção. As indagações também vão no sentido de verificar se o subalterno do cinema brasileiro contemporâneo pode falar, para lembrar o ensaio de GayatriSpivak. Se sim (e essa resposta vai de encontro à tese da teórica indiana), qual seria a parcela de autonomia de sua voz? Que negociações estéticopolíticas precisariam ser feitas, partindo-se da ideia de que a transferência efetiva dos meios de produção da classe média, aquela que filma, para esse outro do cinema brasileiro ainda não foi realizada? 


\section{2}

\section{O cineasta intelectual dos anos 60}

O cineasta sempre foi testemunha participante e ativo fabricante de significados, sempre foi muito mais um produtor de discurso cinemático do que um repórter neutro ou onisciente da verdadeira realidade das coisas.

Bill Nichols

O surgimento do intelectual, em sua acepção moderna, tem sido datado do fim do século XIX, a partir do polêmico caso Dreyfus. Alguns autores, entretanto, indagam se, de fato, não é entre os filósofos da Grécia Antiga que estaria o nascimento do intelectual. Francis Wolff data do século V a.C., na Grécia, três condições reunidas para a manifestação do intelectual. Além de homens com tempo livre que pudessem se dedicar ao cultivo das ideias e "à sua produção e difusão", era preciso, também, "uma consciência do universal com o "nascimento da razão' (encarnada na filosofia e nas ciências puras); e um regime, que permitia a expressão das opiniões e fazia da troca dessas opiniões no espaço público a condição mesma do poder" (WOLFF, 2006: 48).

Ainda segundo Wolff, já se discutia, à época, o papel desses filósofos na sociedade e os problemas de sua adesão à política vigente (problema que mais tarde será retomado em outros termos e em formas mais complexas, leia-se engajamento). Por ora, o conflito que se acirrou na divisão entre os socráticos e os sofistas buscava compreender a atuação do intelectual. O dilema que se colocava sugere como opções o pensamento sobre o real e as indagações em torno dele, a fim de propor um ideal, opinião da qual os socráticos compartilhavam; e a defesa do real, proposta ligada aos sofistas, que se colocavam na Cidade a fim de fazer desta a matéria de suas interrogações. Os sofistas trabalhavam na cidade ensinando a partir do que lhes fosse disponibilizado. Estavam, de certo modo, de acordo com as leis locais e trabalhavam para aquela sociedade, sendo, inclusive, remunerados por esse trabalho. Sócrates fazia a crítica dessa realidade em nome de um ideal: "Quem é o mais irresponsável, o que aceita servir de caução a certos 
regimes, ou o que recusa defender qualquer regime que seja, porque todo regime é corruptível e, portanto, virtualmente corrupto?" (Ibidem: 61)

A pergunta nos leva a questionar a concepção de Sócrates como intelectual, no sentido estrito que a palavra ganhou com o caso Dreyfus. Por outro lado, tal como Wolff resgata o papel de Sócrates, parece-nos relevante não considerar desde já a questão do engajamento como algo resolvido. Posteriormente, todos os debates sobre o papel do intelectual ao longo do século XX terão como convergência o juízo diante do engajamento. É certo que Sócrates, na crítica dos sofistas, pouco se colocou no debate público, isentando-se de assumir uma atitude de intervenção na realidade. Entretanto, a trajetória do filósofo permite, sim, colocá-lo como um dos precursores da gênese do intelectual. As ideias "tortas" com que Sócrates infringiu à constituição ateniense deram a ele a "aura de pensador perseguido", tanto pelas instituições como por anti-intelectuais - caso de Aristófanes, cujo panfleto antisocrático, difamatório e polêmico levava a conclusões como a de que as ideias de Sócrates fariam com que filhos acabassem por “dar pancadas nos próprios pais!” (Ibidem: 49)

Por sua vez, os sofistas, como constituintes de um coletivo de pensadores "porta-vozes de todos os debates fundamentais do século", teriam mais força como movimento histórico no reconhecimento intelectual. Wolff os caracteriza como "os verdadeiros intelectuais no sentido moderno do termo" porque são os "primeiros profissionais a viver da venda de sua competência intelectual" (Ibidem: 55). Com argumentos defendidos de ambos os lados, o autor se pergunta retoricamente quem são os primeiros intelectuais da história e responde, sem o intuito de polarizar para um dos lados:

O mais célebre herói da razão, sozinho contra os poderes, ou o maior movimento racionalista do pensamento antigo? Pois há duas maneiras de ser um intelectual: ou sozinho contra todos (e ele é mais reconhecido pela história, menos por seu tempo), ou acompanhado de outros (ele é mais eficaz em seu tempo, menos aceito pela história). O intelectual é aquele que coloca à Cidade todas as questões que ela não se coloca, isto é, as interrogações fundamentais (como Sócrates?), ou aqueles que, inversamente, partem das questões que a Cidade se coloca, ou que se colocam na Cidade para fazer dela a matéria de suas interrogações (como os sofistas?) (Ibidem: 61)

$\mathrm{Na}$ esteira do debate entre socráticos e sofistas, podemos considerar a noção que Pierre Bourdieu concebe do "intelectual total", encarnado em Jean-Paul 
Sartre - e o argumento de Bourdieu é mesmo construído a partir da figura de Sartre. O intelectual total sartreano é aquele que se coloca em quaisquer assuntos, independentemente do seu campo de atuação profissional, em nome de valores universais que não são afetados por suas particularidades profissionais, amorosas ou partidárias. Este intelectual total tem como resultado de sua ação

instaurar uma relação dissimétrica tanto com os filósofos quanto com os escritores, presentes ou passados, que ele pretende pensar melhor do que eles se pensam, fazendo da experiência do intelectual e de sua condição social o objeto privilegiado de uma análise que acredita perfeitamente lúcida. (BOURDIEU, 1996: 238)

Partindo desse pressuposto, atribuiríamos a origem dos intelectuais na história da humanidade aos sofistas, já que estes agiam de tal modo e foram alvo de críticas justamente por terem ingerência nos mais diversos assuntos e debates que não lhes diziam respeito. Entretanto, havia por parte dos sofistas o envolvimento com o poder, característica que os afasta do modelo sartreano de intelectual. A realidade para Sartre constituiu-se sempre como ponto de partida para um ideal universalista, pois, para ele, "a razão não é uma faculdade de pensar o ideal, mas a faculdade de avaliar o possível" (WOLFF, 2006: 66). É o mesmo Sartre quem nos alerta, na série de conferências proferidas e publicadas, que a universalidade concebida como algo dado é uma postura conformista. Em nome do universal, há, sim, a eterna busca da universalidade porvir.

A defesa que Sartre faz do intelectual como "alguém que se mete no que não é de sua conta e que pretende contestar o conjunto das verdades recebidas, e das condutas que nelas se inspiram, em nome de uma concepção global do homem e da sociedade" (SARTRE, 1994: 14) é a mesma que será alvo do que Bourdieu chama de "dominação simbólica"

(porque falam em nome das ideias, dos ideais e dos valores, e não dos interesses particulares); eles dispõem, portanto, de uma capacidade de impor normas de julgamento e, por isso, não importa o que digam e façam, há necessariamente neles uma duplicidade fundamental ante o poder, que eles criticam tanto mais quanto porque são fascinados por ele e exercem eles próprios, à sua maneira, um equivalente desse poder, ao se erigirem em instância crítica absoluta. (WOLFF, 2006: 64) 
Nesse mesmo sentido, a crítica de Norberto Bobbio também recai no poder ideológico que os intelectuais sempre carregaram consigo, ao lado do poder político e do poder econômico, exercendo ação "sobre as mentes pela produção e transmissão de ideias, de símbolos, de visões do mundo, de ensinamentos práticos, mediante o uso da palavra" (BOBBIO, 1997: 11). Assim como o poder político é dotado, em última instância, de armas, e o econômico, da acumulação de bens materiais, "o principal meio do poder ideológico é a palavra, ou melhor, a expressão de ideias por meio da palavra, e com a palavra, agora e sempre mais, a imagem". (Ibidem: 12)

Cabe lembrar que a palavra, de que fala Bobbio, exerceria um poder, mas um poder de falar em nome do valor universal. É em nome do universal, utilizando a palavra como arma, que o escritor francês Émile Zola intervém no caso Dreyfus. Uma breve narrativa sobre o caso: em setembro de 1894, a tensão em que viviam França e Alemanha colocava ambos os países em permanente expectativa de conflito com seus serviços de espionagem. Na embaixada alemã, em Paris, o fato de o adido militar alemão MaximilienvonSchwartzkoppen jogar documentos importantes na lixeira, inclusive as cartas de amor que trocava com o adido militar italiano Alessandro Panizzardi, deixava em alerta a espionagem francesa. Foi por esse meio que a espiã disfarçada de faxineira encontrou uma carta "prometendo informações sobre peças de artilharia do Exército francês. Evidência de que algum oficial transmitia segredos militares para a Alemanha" (COELHO, 2006: 105).

Durante a investigação alguns nomes foram levantados, dentre os quais, o do oficial judeu Alfred Dreyfus. Havia outros suspeitos e algumas provas foram eliminadas para que o exército chegasse rapidamente a um consenso. A pressão sobre o caso fez com que a opinião pública se convencesse do crime de Dreyfus. Entretanto, ficava mais clara a inocência do oficial, de modo que dentro do próprio exército surgiram dissidências e o levantamento de suspeitas sobre a instituição. Dreyfus foi acusado e preso, fato que levou a multidão e a imprensa antissemita a comemorar a decisão. Em janeiro de 1898, Zola publicou no jornal L'Aurore o panfleto J'accuse, onde tecia uma série de acusações ao exército e às suas omissões, apontando, inclusive, os nomes de todas as autoridades militares envolvidas no caso. 
Na contrapartida do J'accuse e dos demais manifestos que se seguiram a este, assinados por artistas, críticos, filósofos, Maurice Barrès, juntamente com críticos acadêmicos, alguns membros da Academia Francesa, alguns poetas e escritores da literatura conservadora, colocaram-se como defensores da honra do Exército e da pátria francesa. Partiu de Barrès a definição de Zola como um "intelectual", aplicando pela primeira vez o termo e em sentido negativo, de tal modo que a invenção do intelectual se deu antes por uma atitude anti-intelectual. Historicamente, o papel de Zola é inquestionável como homem dotado da razão que intervém em nome de ideais iluministas, como Justiça e Verdade, embora Sartre aponte já no surgimento do termo uma certa carga maldita que acompanhará os intelectuais em toda sua trajetória, como pessoas que,

tendo adquirido alguma notoriedade por trabalhos que dependem da inteligência (ciência exata, ciência aplicada, medicina, literatura etc.), abusam dessa notoriedade para sair de seu domínio e criticar a sociedade e os poderes estabelecidos em nome de uma concepção global e dogmática (vaga ou precisa, moralista ou marxista) do homem. (SARTRE, 1994: 15)

Essa concepção global que Sartre cumpriu à risca - nos seus escritos políticos e filosóficos, na literatura engajada e em sua atuação no Partido Comunista ou mesmo fora dele - foi alvo inúmeras vezes dos que denunciaram o poder dos intelectuais. Nesse breve levantamento que fizemos a respeito de algumas questões que envolvem o intelectual, é importante ressaltar, já na segunda metade do século XX, o embate entre Sartre e Foucault - este último, um teórico ligado antes à corrente estruturalista francesa, mas que, num segundo momento, no viés filosófico da desconstrução, constituiu um pensamento voltado para a análise das estruturas de poder nas instituições e nos discursos. De uma fase à outra, Foucault se propôs, por exemplo, a dar voz ao outro, no Grupo de Informação Prisões (GIP), depois de ter escrito livros que abordavam a loucura e o cárcere (História da loucura e Vigiar e punir). Em Microfísica do poder, Gilles Deleuze destaca essa transição: "Depois você sentiu a necessidade de que pessoas reclusas, pessoas que estão nas prisões, começassem a falar por si próprias, fazendo assim um revezamento" (FOUCAULT, 1979: 70)

A postura de Foucault, claramente oposta a de Sartre, opera um deslocamento do lugar de representante para o de questionador dessa representação, “o papel do intelectual (...) é antes o de lutar contra as formas de 
poder exatamente onde ele é, ao mesmo tempo, o objeto e o instrumento" (Ibidem: 71). Não caberia mais ao intelectual "a indignidade de falar pelos outros", representar uma consciência coletiva, mas colocar-se no seu lugar de teórico, desconstruindo os discursos de poder a fim de fazer o outro, subalterno, falar por si. Nada mais distante das convicções dos cineastas brasileiros dos anos 60 do que considerar o falar pelo outro uma indignidade. Ao contrário, naquele contexto político o sonho das esquerdas era alimentado por um dos braços fortes do movimento, a cultura.

\section{1.}

\section{Projeto utópico no cinema brasileiro moderno}

O projeto de revolução das esquerdas no Brasil, surgido já na década de 1930, renasceu com mais vigor no início dos anos 60, com a proposta de Reformas de Base do presidente da República João Goulart. Nesse contexto político, o sonho das esquerdas era alimentado por um dos braços fortes do movimento, a cultura. Embora a produção artística e cultural ligada às esquerdas tivesse uma amplitude que cobria as mais variadas manifestações artísticas - a literatura, a música e o teatro, por exemplo - o locus de maior promessa de transformação social foi o cinema ${ }^{1}$. A crença no potencial do cinema como deflagrador coletivo de uma consciência revolucionária era bastante corrente entre os artistas da esquerda. Além disso, a partir do pós-guerra e até os anos 60, uma série de novas cinematografias apareceu em diversas partes do mundo, dada a inventividade na abordagem de novos temas e a novidade dos recursos técnicos que possibilitaram a renovação da linguagem, configurando-se no que hoje conhecemos como cinema moderno.

No Brasil, uma nova geração fazia a crítica das malogradas tentativas de industrializar o cinema nacional. No caso, a Companhia Cinematográfica Vera Cruz, cuja produção se opunha ao cinema de Hollywood, mas conformava-se em copiar o "ranço" do cinema clássico europeu, num período em que o mundo estava assistindo ao surgimento dos cinemas modernos. Mesmo quando tentou

\footnotetext{
${ }^{1}$ Ver a esse respeito o texto $A$ obra de arte na era de sua reprodutibilidade técnica, onde Walter Benjamin discorre sobre as possibilidades de revolução a partir da invenção do cinema.
} 
incorporar o neorrealismo, a Companhia não obteve êxito, já que o foco de sua produção estava centrado nos grandes estúdios. Ademais, os filmes da Vera Cruz tinham pouca adequação à cultura brasileira, eram produzidos em estúdios caros tal como o modelo norte-americano que criticavam - e empregavam em suas produções mão de obra importada da Europa, o que contribuía para descaracterizar a abordagem da realidade brasileira. Assim, como esclarece Pedro Simonard, a Vera Cruz serviu de "parâmetro negativo" para o germe do Cinema Novo, representando o que "deveria ser rejeitado e descartado na produção de um cinema nacional e popular" (SIMONARD, 2003: não paginado). A alienação e o reforço dos "modelos que submetiam o público brasileiro à dependência cultural" explicitava-se em sua linguagem "reacionária e burguesa por não retratar o homem brasileiro, sua cultura, seus problemas, sua forma de falar nem retratar o ambiente do país" (Ibidem: n/p). Num outro diapasão, a crítica recaiu sobre a chanchada, cujo principal mote era parodiar o cinema hollywoodiano, mas que, ainda assim, faltava com um sentido de cinema intelectual e com a representatividade dos menos favorecidos. Em suma, fazia a denúncia do povo às classes dominantes (GLAUBER apud SIMONARD, 2003: n/p).

O debate acerca do cinema que se produzia nos anos 40 e 50 está exposto no texto de Paulo Emílio Salles Gomes, do qual falam Maria Rita Galvão e JeanClaude Bernardet, no livro que discute o nacional e o popular na cultura brasileira. Segundo os autores, Paulo Emílio escreveu o polêmico "Uma Situação Colonial?", questionando a importação de filmes e, por conseguinte, de estéticas e ideologias estranhas à nossa realidade. Contestado por Roberto Schwarz ${ }^{2}$, para quem a situação colonial do Brasil terminara em 1822, Paulo Emílio mostrava que esse tipo de escambo continuava em vigor na medida em que as coproduções utilizavam "cineastas estrangeiros de nossas histórias, paisagens e humanidade" (GOMES apud GALVÃO, BERNARDET, 1983: 166) e, em contrapartida, nos devolviam seus produtos manufaturados com nossa cultura transformada em algo exótico (vide Orfeu do Carnaval, de Marcel Camus, citado pelos autores). Assim, os autores, não obstante o erro conceitual apontado por Schwarz, reforçam a ideia de Paulo Emílio:

\footnotetext{
${ }^{2}$ De acordo com Bernardet e Galvão, “debate Arte e Política, Paço das Artes, 14.5.79, transcrição datilografada a partir de gravação, arquivo FCB”.
} 
O fator básico que explica a "situação colonial" do cinema brasileiro é o fato de que o "produto importado" ocupa o seu lugar. Trata-se, portanto, de uma definição de ordem econômica que será metaforicamente transposta para o campo da cultura. Importamos não apenas objetos manufaturados, mas ideias prontas - e formas, modelos, estruturas de pensamento - forjadas em função de realidades diversas que correspondem mal à nossa própria realidade. Estas ideias ocupam um tal espaço em nossas mentes que pouco sobra para que nelas se desenvolvam ideias próprias. Além de produtos industriais, os filmes são também produtos culturais. Juntamente com os filmes, importamos toda uma concepção de cultura - e uma concepção de cinema que identifica com o próprio cinema o cinema estrangeiro. Nisto reside o cerne da "colonização" cultural: a "situação colonial" - cuja "marca cruel" e inescapável é a mediocridade - se configura quando se adota um modelo importado que não se tem condições de igualar. (Ibidem: 1667).

Em 1965, no manifesto Uma estética da fome, Glauber Rocha, peça fundamental no movimento do Cinema Novo, propunha uma abordagem da realidade distinta da que a população brasileira estava habituada a assistir nos cinemas. Para ele, o observador europeu ${ }^{3}$ só se interessa pelos processos de criação artística no mundo subdesenvolvido "na medida [em] que satisfazem sua nostalgia do primitivismo; e este primitivismo se apresenta híbrido, disfarçado sob as tardias heranças do mundo civilizado (...), impostas pelo condicionamento colonialista"4. Ainda que o manifesto citado datasse de um período pós-golpe militar, todas as ideias que foram seminais para a criação do Cinema Novo encontravam-se naquele panfleto.

Ao abordar as relações entre cultura e política, José Mário Ortiz Ramos não deixa de destacar o papel do cinema, cujo corpo-a-corpo nas lutas culturais dos anos 50-60 chegou ao ponto de criar uma "superposição e entranhamento entre os processos estético-cultural e político-social” (RAMOS, 1983: 11). Superposição esta que reelaborou o cinema frente às necessidades de tomada de posição política e intelectual, criando o tipo de estética que se almejava no manifesto de Glauber. O cineasta Maurice Capovilla chegou a diagnosticar, nos filmes baianos precursores do Cinema Novo, a cessão do caráter meramente estético em prol do político:

\footnotetext{
${ }^{3}$ Por mais óbvio que possa parecer, é preciso chamar atenção aqui para o fato de que ao tratar do “observador europeu”, Glauber sintetiza a questão, não significando, entretanto, esquecer do colonialismo cultural imposto pelos EUA e pelo cinema de Hollywood. Pelo contrário, foram estes últimos alvos constantes do cineasta em toda a sua trajetória.

${ }^{4}$ ROCHA, G. Manifesto Uma estética da fome. In: http://tropicalia.uol.com.br/site/internas/leituras_gg_cinenovo.php, publicado originalmente na Revista Civilização Brasileira, $\mathrm{n}^{\circ} 3$, julho de 1965.
} 
São feitos para atuar de imediato, predispondo tomadas de consciência pelo povo dos problemas mais agudos do momento. São filmes que, certamente, não entrarão na história do cinema pelo seu "valor artístico", pois são obras condenadas a servir o momento histórico, são armas, utensílios, formas temporães (sic) de difusão de uma cultura pragmática, interessada sobretudo na resolução dos problemas sociais do homem. (RIDENTI, 2000: 90)

É preciso fazer as ressalvas dos excessos panfletários cometidos em alguns filmes, como o próprio Capovilla enfatizou, mas se faz necessário também ressaltar nesta citação um posicionamento de purismo estético, quanto ao conjunto de filmes mencionados, visto que a proposta da estética da fome seria a de produção de um cinema crítico voltado para as questões sociais. Nesse sentido, lembremos a resposta dada por Jean-Claude Bernardet aos detratores de Aruanda (1960), filme curta-metragem de Linduarte Noronha, um dos precursores do cinema brasileiro moderno. Diz Bernardet aos que acusaram o filme de primitivo à época de suas primeiras exibições: "O primitivismo se caracteriza mais pela ingenuidade de visão e do modo de reprodução da realidade, e não implica uma técnica deficiente e simples" (BERNARDET, 2007: 38), não resultando, portanto, em demérito para o conjunto de filmes produzidos pelo embrião do Cinema Novo. $\mathrm{E}$, se assim fosse, haveríamos de nos interrogar a respeito do mérito conquistado por todas as manifestações artísticas que, de algum modo, estiveram ligadas às questões políticas de sua época, incluindo quase toda a produção cultural brasileira dos anos 60 e uma grande parte do cinema mundial.

No que diz respeito a essa relação política-cultura, Marcelo Ridenti fornece dados importantes para a compreensão do romantismo revolucionário e os modos como este levou consigo uma classe inteira de artistas. Aqui, no entanto, vamos nos restringir à declaração do autor, de que havia "aspectos da constituição do romantismo revolucionário nos meios intelectualizados da sociedade brasileira nos anos 60 e início dos anos 70, marcados pela utopia da integração com o homem simples do povo brasileiro" (RIDENTI, 2000: 12). Ainda segundo Ridenti, num movimento de mão dupla com o cinema que se alimentou das questões políticas e sociais, a esfera intelectual e política começou a se aperceber do espaço que a realidade vinha ocupando nas representações culturais. Destacamse, então, essas manifestações artísticas em ambientes antes ocupados majoritariamente por reflexões políticas, sociais e filosóficas: 
$\mathrm{O}$ ascenso da realidade nacional nas artes, após o êxito da peça de Guarnieri, Eles não usam black-tie, levou a revista Brasiliense, cada vez mais, a abrir suas páginas para a produção cultural do momento. A partir do número 32 , de novembro-dezembro de 1960 - ao lado da tradicional seção de livros, com resenhas de lançamentos editoriais de ensaios e também de literatura -, surgem em quase todos os números breves críticas sobre a dramaturgia e as peças em cartaz, com enfoque privilegiado ao teatro brasileiro engajado, sobretudo o Teatro de Arena e o CPC. A partir do número 41, de maio-junho de 1962, o cinema também passou a ser objeto de críticas na revista, correspondendo ao surgimento do Cinema Novo. O tom das críticas era de franca simpatia pelas diversas abordagens artísticas da realidade nacional. (Ibidem: 84)

Para lograr o desempenho pretendido, além do apoio que vinha recebendo de parte da ala teórica da esquerda, o Cinema Novo, representado, sobretudo, na figura de Glauber Rocha, cujo temperamento arredio fazia com que chamasse atenção para as causas do cinema em prol do "povo", precisava mostrar o caminho de transformação, apontando também o que estava errado nas atuais representações culturais da nação. Fazia-se necessário, por exemplo, o desmantelamento de modelos de comportamento que as camadas urbanas e a burguesia importavam da produção cultural estrangeira, principalmente de Hollywood: "Diante disso, a necessidade de se criarem condições para que o artista brasileiro pudesse enfrentar as produções estrangeiras era uma das frentes de atuação dos nacionalistas" (SIMONARD, 2003: não paginado). Na prática, significaria fazer com que o cinema, aproveitando-se de sua dupla face - a de comunicação de massa, sem abrir mão da artística - "ocupasse os espaços do cinema estrangeiro ou que, ao menos, conseguisse dele tomar uma fatia do mercado brasileiro". (Ibidem)

A visão, exposta acima, de tomada dos meios de produção obedeceu menos a um desejo de crescimento econômico e ganho de status do cinema brasileiro, do que a um "objetivo econômico-político-cultural integrado" com o intuito de gerar "uma ideologia política através do produto que é feito, pois queríamos fazer filmes que tivessem como objetivo a realidade brasileira, dentro de uma perspectiva revolucionária", como afirmou Glauber em entrevista a Raquel Gerber (GERBER et al., 1977: 11). O objetivo primeiro do Cinema Novo foi o de se posicionar na busca de uma utopia, falando sempre em nome de um povo que não tinha voz e fazendo disso profissão de fé: “onde houver um cineasta (...) pronto a pôr seu cinema e sua profisssão a serviços das causas importantes de seu tempo, aí haverá um germe do Cinema Novo" (ROCHA, 2004: 67). 
Uma vez efetivada a tomada dos meios de comunicação de massa (etapa de superação da estética e da ideologia do colonizador), o próximo passo do projeto se constituiria em representar os desfavorecidos. Marcelo Ridenti enfatiza a trajetória de artistas e intelectuais de esquerda, presentes de modo marcante na política dos anos 60 até os anos 80, ora pelas declarações dadas à imprensa ou na participação em campanhas políticas, ora nas próprias obras, numa "superrepresentação das classes médias na política brasileira contemporânea, diretamente proporcional às dificuldades de representação das outras classes". (RIDENTI, 2000: 52). Como afirma o autor, esses "tradutores de demandas sociais" têm função de grande importância

numa sociedade na qual os direitos de cidadania não se generalizam para o conjunto da população, em que classes não se reconhecem enquanto tais, não identificando claramente o seu outro, encontrando dificuldades para fazer-se ouvir, ou mesmo para articular a própria voz (RIDENTI, 2000: 55)

Assim, imbuídos da missão de transformar a sociedade e representar os sem voz, diretores do Cinema Novo estavam cientes de "sua direta relação com o momento político em filmes onde falou a voz do intelectual militante, sobreposta a do profissional de cinema" (XAVIER, 2001: 57). Em entrevista a Raquel Gerber, Glauber Rocha apresentou a face do Cinema Novo que guarda poucos pontos de contato com a concepção vigente do cinema como cultura de massa:

\footnotetext{
Nunca a gente pensou que o cinema devia ser uma profissão burguesa, uma arte de consumo ou uma indústria de sucesso. Era apenas um meio de comunicação mais avançado que os intelectuais de esquerda usavam porque todo mundo que fazia cinema novo queria naturalmente militância entre as práticas intelectuais, quer dizer, um grupo que deu um salto qualitativo porque ia em direção a um meio novo. (GERBER, 1977: 14)
}

Por outro lado, o Cinema Novo buscou inspiração no engajamento artístico, já observado na escrita da literatura de 1930 e que, agora, era fotografado no cinema de 60. Esse diálogo, muitas vezes mais destacado pelas adaptações que o Cinema Novo fez dos textos literários, está presente de modo mais profundo na militância política, no intuito de "trazer para o debate certos temas de uma ciência social brasileira, ligados à questão da identidade e às interpretações conflitantes do Brasil como formação social." (XAVIER, 2001: 19). Esses discursos sobre a realidade brasileira, presentes já naquela literatura, faziam 
parte da ordem do dia. Para Glauber, "nos dias de hoje, o importante é fazer filmes de todas as espécies, para imprimir consciência ao Brasil e excitar a revolução" (VIANY, 1999: 26).

Se para nós é evidente o papel que a arte desempenhou nas manifestações artísticas e sua importância em países da América Latina na defesa da cultura nacional, o artista visto como intelectual não é exclusividade dos países do terceiro mundo. Esse produtor cultural engajado circula nas esferas políticas para nela intervir, configurando-se assim seu papel na transformação social, como esclarece Pierre Bourdieu ao discutir o papel dos intelectuais no mundo:

Os intelectuais surgiram historicamente no e pelo ultrapassamento da oposição entre a cultura pura e o engajamento. São por isso seres bidimensionais. Para invocar o título de intelectual, os produtores culturais precisam preencher duas condições: de um lado, pertencer a um campo intelectualmente autônomo, independente do poder religioso, político, econômico e outros, e precisam respeitar as leis particulares desse campo, de outro lado, precisam manifestar sua perícia e autoridade específicas numa atividade política exterior ao campo particular de sua atividade intelectual. Precisam permanecer produtores culturais em tempo integral sem se tornar políticos. (BOURDIEU apud CHAUÍ, 2006: 20)

\section{2.}

Intelectuais no filme e fora deles - a construção do povo

O propósito de intervenção no espaço público brasileiro, por parte dos diretores do Cinema Novo, pautou a escolha dos temas de seus filmes, incluindose aí as questões que levantavam sobre a própria condição do cineasta-intelectual como representante do caminho político-cultural para a revolução. Revolução que deveria ser realizada a partir da tomada de consciência do povo para o qual os filmes se dirigiam. Para isso, foi necessário se pensar um cinema popular, com todos os problemas que essa discussão poderia trazer. Entre os quais, o grau de valorização e/ou de alienação do povo nas telas, no que tange a temática abordada, e a linguagem através da qual o cinema ia construir seus discursos. Neste ponto, trazer a crítica que Glauber faz à "visão cultural paternalista do CPC" nos coloca mais próximos da proposta do Cinema Novo. Para o diretor, era necessário 
não confundir a comunicação da alienação com comunicação revolucionária (...) a massa não é facilmente conquistável (...) Nós nos recusamos a idealizar o proletariado: é a massa marginalizada que representa o câncer inconsciente do Brasil e é sobre os marginais que o cinema novo desceu. (GERBER, 1977: 16)

Do mesmo modo e ainda no final dos anos 60, Jean-Claude Bernardet, fazendo uma crítica no calor da hora e abordando de forma perspicaz a produção cinematográfica daquele período, apontou a visão esquematizada que o CPC fazia da sociedade. O autor se refere especificamente ao filme Cinco vezes favela (produção em que cinco diretores - Joaquim Pedro de Andrade, Miguel Borges, Marcos Farias, Carlos Diegues e Leon Hirzsman - narram histórias ambientadas na favela), de 1961:

O CPC pretendia, por meio de peças de teatro, filmes ou outras atividades, levar a um público popular informações sobre sua condição social, salientando que as más condições de vida decorrem de uma estrutura social dominada pela burguesia. Tarefa de conscientização: deve-se ir além da descrição e da análise da realidade, a fim de levar o público a atuar; a situação não mudará se ele não agir para transformá-la e só ele pode ser o motor dessa transformação. Trata-se de politizar o público. Essa militância é a finalidade de Cinco vezes favela. (BERNARDET, 2007: 41)

No mesmo ano de Cinco vezes favela, seria lançado Barravento, filme paradigmático do Cinema Novo, pela complexidade com que discutia a oscilação problemática entre o tempo linear, iluminista e teleológico e a noção de tempo religioso e circular. Segundo Ismail Xavier, Barravento seria "a equação irresolúvel que confronta essas duas perspectivas, recusando o ponto de vista transcendente que, exterior a elas ou privilegiando uma delas, avançaria a resposta una e fecharia o discurso" (XAVIER, 2007: 51). Ambientado na comunidade de pescadores Buraquinho, o filme de Glauber narra a trajetória do personagem Firmino, que volta da cidade para a comunidade, e chega para desestabilizar o esquema de opressão a que são submetidos os pescadores, dependentes de uma rede cujo aluguel representa $90 \%$ da pesca. Além do problema político-econômico dos pescadores, Barravento insere na discussão sobre mitos religiosos o personagem Aruã, rapaz virgem protegido de Iemanjá, responsável espiritual por manter em harmonia a comunidade. O plano de Firmino está em desmistificar as crenças religiosas e acabar com a exploração do dono da rede. 
Assim, a alusão que se faz ao papel de Firmino como intelectual das luzes é bastante pertinente na leitura crítica do filme e também nos propósitos de Glauber quando intuiu um cinema desmistificador de tecituras religiosas e de esquemas escusos da política e da sociedade. Jean-Claude Bernardet afirma o estranhamento de Buraquinho em relação ao personagem - "Firmino já não pertence mais, pois sua atual personagem foi formada pela cidade; mas tampouco pertence à cidade" (BERNARDET, 2007: 75) - e nos dá pistas correlatas à ideia de um intelectual localizado na instabilidade, cujo movimento está em sair do seu lugar para se colocar no lugar do outro. No caso de Firmino, cuja denominação poderia ser a de um intelectual da classe dos pescadores, o personagem sofre uma alteração já que, como defende Bernardet, não é mais pertencente de sua comunidade, foi preciso um distanciamento de Firmino para que este voltasse e percebesse a engrenagem da qual fazia parte e era vítima.

No campo da linguagem, é interessante observar o cotejamento que Ismail Xavier faz entre Barravento e O pagador de promessas (1962), filme de Anselmo Duarte, vencedor da Palma de Ouro no Festival de Cannes, ao observar as aberturas que Barravento revela em relação ao filme com o qual é comparado. Aberturas que se configuram como adequadas à política cinematográfica de Glauber ao proporem uma relação dialética do filme com o espectador, diferenciando-se do espectador passivo, que se deixa alienar pelas imagens recebidas. Trata-se do que Ismail Xavier chama de discurso da opacidade, cujo caráter explicita ao espectador o fato de que existe algo oculto naquele discurso e que, por isso, deve-se desconfiar de uma suposta verdade fílmica; em contraposição, o discurso transparente do cinema hollywoodiano, cuja ênfase está na montagem sem brechas, não permite ao espectador ver além do "real"5 que se apresenta na tela. ${ }^{6}$ Se neste segundo esquema, o espectador é pensado como um voyeur que vê sem ser visto ${ }^{7}$; na proposição do Cinema Novo o espectador era

\footnotetext{
5 Um dos mais polêmicos e recorrentes debates da teoria cinematográfica relatados por historiadores do cinema diz respeito ao embate entre as ideias de André Bazin e Sergei Eisenstein. $\mathrm{O}$ crítico francês defendia o plano-sequência e a restrição à montagem, no intuito de que na tela surgisse o real tal como ele é dado fora da sala de projeção. O cineasta russo, por sua vez, foi um dos mais importantes entusiastas do uso da montagem como formadora de um discurso ideológico no cinema, de tal modo que ela não espelhasse o real, mas provocasse a possibilidade de modificação dele.

${ }^{6}$ Sobre a opacidade e a transparência no filme, ver XAVIER, Ismail. O discurso cinematográfico: a opacidade e a transparência. São Paulo: Paz e Terra, 2005.

${ }^{7}$ 'No teatro, a quarta parede 'protegia' a ficção da realidade, mas se ela 'constituía uma barreira para o espectador, também o era para o ator que devia permanecer preso a essa esfera se quisesse
} 
participante, quando não agredido pelas imagens e pelas falas que a ele se dirigiam.

Portanto, a crítica que Ismail Xavier dirige à "costura" do texto em $O$ pagador de promessas dá uma noção do modelo de linguagem buscado pelo Cinema Novo:

Há um esquema que preserva, a todo custo, a autoridade do narrador diante da visão das personagens, mantendo um estilo de representação homogêneo e um foco de visão unificado, em seus valores, ao longo do filme. Há um centro fixo a partir do qual se desenha a visão de mundo que governa a relação narrador/narrado e mantém a nítida separação entre os polos dessa relação. $\mathrm{O}$ desenho tem contornos claros e traz a impressão de que reproduz o real. $\mathrm{O}$ texto organizado imita a evolução contínua da própria vida e sua estrutura é percebida como ausência de estrutura. O efeito é de simplificação, fluir natural, exposição direta dos acontecimentos, mas ele é conseguido à custa de uma complicação extrema da montagem em sua fratura. (XAVIER, 2007: 72)

E, mais adiante:

O jogo de pontos de vista que caracteriza a decupagem clássica constitui um processo de intensa fragmentação da cena. É a multiplicação de visões particulares, em si complicada pelos cuidados que exige, que constrói a impressão de objetividade. A diversificação dos pontos de vista da câmera não significa necessariamente a adesão aos valores e à visão de mundo das personagens. Define apenas uma técnica de exposição, "mais viva e mais dramática", de sua experiência em momentos particulares. Eu, espectador, empresto os olhos da personagem que vê, mas a relação emocional e ideológica que estabeleço com ela, de identificação, indiferença ou repulsa, depende de um emolduramento criado pelo conjunto da narrativa. É da organização geral dos pontos de vista que se pode inferir o princípio que domina a representação. (XAVIER, 2007: 73)

Deste modo, ainda segundo o autor, somos levados a acreditar na contemplação de diversos olhares e pontos de vista, ao passo que, na verdade, a construção narrativa centraliza os olhares dos personagens, subjugando-os sempre à autoridade do narrador central. Em $O$ pagador de promessas, "ganha-se em clareza didática, mas o preço pago é a efetiva distância, mascarada de intimidade, com o universo da personagem, que permanece um objeto do olhar do centro

permanecer personagem'. No cinema, tal aprisionamento ganha mais força, pois o espaço imaginário se projeta na pura superfície (a luz na tela); não há atores no espaço da sala, o que auxilia na produção do efeito de autonomia da ficção. Mas são necessários determinados cuidados para garantir o efeito (o ator não deve olhar para a câmera). Para tanto, foram construídas as regras do cinema clássico que guarda um lugar para o espectador fora do circuito dos olhares que se instala dentro da cena, atento para que a geometria da representação se preserve e a ficção se proteja do real, mantida a separação entre olhar e mundo diegético." XAVIER, Ismail. O olhar e a cena: melodrama, Hollywood, Cinema Novo, Nelson Rodrigues. São Paulo: Cosac \& Naify, 2003. p. 18 . 
organizador das imagens." (Ibidem: 74). O que o filme de Glauber propõe é a dissolução da linguagem clássica e a apresentação do discurso opaco, "sem a clareza meridiana do espetáculo mais convencional com seus códigos reconhecíveis" (Ibidem: 74), sem contemplar no sentido da gramática cinematográfica diversos pontos de vista, mas adotando a perspectiva desses personagens na sua abordagem de conteúdo. Barravento propõe a quebra hierárquica entre o narrador e o narrado, "entre o olhar industrial posto a funcionar pelo cineasta e o grupo social de que fala a sua ficção" (Ibidem: 75). Em termos de significado da gramática cinematográfica, O pagador de promessas apresentaria uma tendência ao status quo, dada sua visão naturalista e, por vezes, conformadora, ao passo que Barravento, no centro de seu discurso, estaria sempre propondo uma desestabilização dos personagens e dos hábitos da comunidade.

Entretanto, no que se refere à compreensão do filme pelo público, a proposta de um cinema nacional-popular, tal como descrita pelo sofisticado esquema crítico de Ismail Xavier, não conseguiu dar conta dos problemas enfrentados no extrafilme. Alguns críticos já apontaram o problema da comunicação do Cinema Novo e, por conseguinte, sua limitação em atingir pelo discurso intelectual do cineasta os corações dos oprimidos, deixando de impingir neles a vontade de transformação pela revolução. Alex Viany, à época do lançamento de Barravento, lamentou que o filme "será mais bem compreendido (...) pelas plateias mais sofisticadas. E, no estrangeiro, onde certamente terá bonita carreira, corre o sério risco de ser classificado como obra exótica" (VIANY, 1999: 49).

Em relação à Aruanda, curta-metragem precursor do Cinema Novo, já mencionado, Jean-Claude Bernardet - que antes saíra em sua defesa quando Linduarte Noronha utilizou técnica deficiente para tratar de uma realidade igualmente deficiente e precária - demonstrou preocupação com a falta de compreensão do filme por uma plateia composta de operários nordestinos em São Paulo:

O que a fita pretendia dizer não fora comunicado; tal manifestação era também uma indicação sobre o tipo de cinema que poderia atingir o público que mais importava aos cineastas. Mas, isso, nós o entendemos muito superficialmente e, no fundo, não demos importância a esse tipo de compreensão. Tudo seria entendido bem mais tarde. Por enquanto, fazia-se um cinema que não tinha público. Esse fenômeno não é isolado: não é apenas o cinema que não chegava ao 
grande público; era todo um movimento cultural e político. (BERNARDET, 2007: 40)

Com esse diagnóstico, em 1966, Bernardet antevia um mea-culpa não só do Cinema Novo, mas de "todo um movimento cultural e político", que acreditou numa revolução sem consultar a parte revolucionária (povo). $\mathrm{Na}$ contramão da proposta de linguagem palatável para o público, Glauber Rocha defendeu um cinema não como fim, puro entretenimento, mas como ferramenta e meio para alcançar a utopia da nação. Para ele, sendo a comunicação qualitativa, não se fazia necessário apelar com a linguagem medíocre do cinema comercial, pois o conceito de comunicação quantitativa seria "um conceito dos americanos, da $\mathrm{BBC}, \mathrm{McLuhan}$ e todos esses teóricos que ficam dizendo que 'o meio é a mensagem' que é uma frase inteiramente ambígua porque serve justamente para justificar tudo" (GERBER, 1977: 19). No mesmo sentido, mas focando a discussão na cinematografia brasileira, que resolveria o problema na medida em que fosse se estabelecendo como cinema popular-nacional, Leon Hirszman, num debate sobre Deus e o diabo na terra do sol, em março de 1964, com Glauber Rocha, Walter Lima Jr., Alex Viany e David Neves, inseriu também a questão da qualidade do filme:

\begin{abstract}
Carimbar um filme como genial só porque se comunicou com as grandes massas não é o caso. O que é preciso é entender o filme dentro do processo do cinema brasileiro. Não bastá-lo intelectualmente, resolvê-lo intelectualmente. Mas sim entender o que ele significa no processo; porque não é um filme só que vai comunicar, uma visão de mundo só que vai comunicar com a plateia do cinema brasileiro. É toda uma perspectiva de cinema. E este filme é parte dela. (VIANY, 1999: 79)
\end{abstract}

Por outro lado, a resistência do público-alvo em assimilar esse tipo de discurso parecia natural, em princípio, dada a alienação a que foi submetido durante décadas pelos cinemas norte-americano e brasileiro (as chanchadas e o cinema burguês). A própria noção de um intelectual produtor de conteúdo direcionado às classes desfavorecidas poderia já em si suscitar questões, visto que aquele precisava abdicar de sua condição burguesa, classe média, para adentrar no território alheio, e ainda assim conformar-se com a desconfiança de ambos os lados. Sartre nos esclarece a respeito dessa aporia do intelectual: 
se o intelectual, embora não sendo produzido enquanto tal, organicamente, pelas classes desfavorecidas, quiser juntar-se a elas para assimilar sua inteligência objetiva e para dar a seus métodos exatos os princípios formulados pelo pensamento popular, ele enfrenta, de imediato e a título justo, a desconfiança daqueles a quem vem propor aliança. Ele, de fato, não pode evitar que os operários vejam-no como um membro das classes médias, quer dizer, das classes que são, por definição, cúmplices da burguesia. Portanto, o intelectual está separado por uma barreira dos homens cujo ponto de vista deseja adquirir, que é o da universalização. (SARTRE, 1994: 44)

Todavia, para a compreensão da relação intelectual-proletariado, é preciso ressaltar a atuação peculiar do Partido Comunista no Brasil e, por consequência, obter uma ideia da atuação de quase toda a esquerda e dos movimentos culturais que a ela se seguiram, incluindo aí as orientações políticas do Cinema Novo, embora este não estivesse diretamente vinculado ao PCB. Chamamos peculiar porque não obedecia estritamente à cartilha comunista internacional, visto que lutava pela utopia da igualdade num país colonizado terceiro-mundista, onde os problemas de subdesenvolvimento ainda estavam bastante atrelados à exploração advinda dos mecanismos econômicos e políticos das nações imperialistas. Deste modo, a luta contra o imperialismo (exterior) se sobrepunha à luta de classes (interior). Ao examinar a atuação do Partido Comunista no Brasil, Francisco de Oliveira vê na luta de classes um papel secundário (ou uma medida posterior), num panorama em que se mostrava mais manifesta a tomada de posicionamento no período da Guerra Fria e, concomitantemente, a luta contra o capitalismo:

No princípio, o Partido (comunista) insistiu na centralidade da classe operária, para depois se deslocar para o tema da revolução burguesa como porta de passagem obrigatória para uma revolução proletária. A guerra fria levou a produção marxista do Partido a concentrar-se no tema do imperialismo, uma notável aquisição para o repertório brasileiro, mas que, do ponto de vista de uma teoria do capitalismo na periferia, na verdade pouco ultrapassou os umbrais do nacionalismo, e, posteriormente, com a hegemonia do pensamento da CEPAL, a orientação e a produção teórica comunista no Brasil terminou sendo um mix de cepalismo e nacionalismo. (OLIVEIRA, 2006: 297)

Ainda quanto a esta questão, Roberto Schwarz afirma que "antes de 1964, o socialismo que se difundia no Brasil era forte em anti-imperialismo e fraco na propaganda e organização da luta de classes" (SCHWARZ, 2005: 10), em parte pela pregação da aliança que o Partido Comunista estabeleceu com a burguesia, resultando numa "espécie desdentada e parlamentar de marxismo patriótico, um complexo ideológico ao mesmo tempo combativo e de conciliação de classes" 
(Ibidem: 10). Schwarz argumenta que a situação era bastante confortável para a burguesia populista, pois esta "precisava da terminologia social para intimidar a direita latifundiária, e precisava do nacionalismo, autenticado pela esquerda, para infundir bons sentimentos nos trabalhadores" (Idem).

Poderíamos, então, especular sobre uma burguesia que pegou carona no movimento cultural e político, e, em consequência disso, só fez aumentar o fosso que ia se revelando intransponível entre diretores-intelectuais e proletariado. É mais uma vez que recorremos a Jean-Claude Bernardet, em sua crítica obstinada ao paternalismo de determinados filmes do período, de modo a querer revelar uma ideologia por detrás dos problemas que os filmes apresentavam. Para o autor, em alguns filmes o problema da trama tendia a ser sempre apresentado com uma solução, "o resultado dessa estrutura dramática simplista não era um convite à politização, mas sim à passividade. Pois o espectador não tem de fazer o esforço de extrair um problema da realidade apresentada no filme" (BERNARDET, 2007: 42) e se quisesse discutir o problema apresentado, "a realidade do filme não forneceria elementos para tanto" (Ibidem: 42).

A partir disso, Bernardet depreende que todo o debate em torno do dilema de apresentar ou não soluções, colocar o problema para o público ou apontar a solução, eram "preocupações infantis", que, embora se justificassem pela "necessidade de uma comunicação imediata com o público, de uma ação urgente, e que também refletem atitudes que ultrapassam o âmbito do cinema" (Ibidem: 49), tais preocupações revelariam, no seu subtexto, o desejo de manutenção da aliança entre classes; as manifestações em torno dos filmes "não eram realmente questões de dramaturgia, mas antes manifestações de uma atitude paternalista cuja finalidade é controlar a massa" (Idem).

Para Bernardet, no cinema brasileiro, o paternalismo na representação do povo se manifestava de várias formas. O cenário era sempre composto de "proletários sem defeitos, camponeses esfomeados e injustiçados, hediondos latifundiários e devassos burgueses" que invadiam a tela. Configurava-se, assim, num movimento da classe média em direção ao povo, fenômeno cíclico, que ocorria "sempre que a pequena burguesia, marginalizada, não pode mais confiar integralmente numa burguesia sem perspectiva" (Ibidem: 49). É o caso de Assalto ao trem pagador (1962), de Roberto Faria, onde o favelado Tião Medonho não se sente bem cometendo crimes, mas também não consegue se integrar à sociedade. 
Em contraposição, o bandido Grilo - que não fazia parte da favela, tinha uma amante da high society carioca e tentava ascender na alta burguesia -é morto pelo diretor porque "as aspirações dele não se dirigem à classe média, mas sim à alta burguesia" (Ibidem: 63). As últimas palavras de Grilo denotam o caráter vilanesco do personagem: "você pensava que o dinheiro ia fazer você ficar bonito, Tião?! (...) você é feio, sujo, fedorento. Eu tenho cara de ter carro, tenho olho azul e você... você tem cara de macaco. Macaco!”. Tião, por sua vez, agoniza na cama do hospital, cercado pela mulher e pelo filho Toninho, ao som de uma melodia que alterna entre o melodramático e o melancólico. Para Bernardet, "o marginal heroizado não pode senão morrer no fim do filme, e sua morte é a extinção de uma força da natureza" (Ibidem: 64). Com a casa sendo violentamente devassada por jornalistas e policiais, a viúva destrói com um machado o armário onde estava guardado todo o dinheiro do assalto, impossibilitando, assim, qualquer chance de dar aos filhos um futuro digno.

Numa outra vertente, passando por cima de todas as questões relacionadas à compreensão do espectador e do apaziguamento da luta de classes, Glauber Rocha lança, em 1964, Deus e o diabo na terra do sol, proposta radical e interessante pelo olhar mais crítico lançado sobre o excluído. $\mathrm{Na}$ trama, o vaqueiro Manuel é, primeiro, levado a cometer um assassinato contra o coronel Morais, o explorador da terra e do homem. Mais adiante, sem saída para suas mazelas, acompanhado da mulher Rosa, faz uma peregrinação religiosa até Monte Santo, sob o jugo do beato Sebastião, com a promessa de dias de fartura e fim do sofrimento. O trajeto de Manuel coloca na tela o espectador e/ou traz para a plateia a experiência do sofrimento, quando cola a narração na experiência, "havendo cenas onde o espectador é destituído daquela visão privilegiada de quem observa organizadamente, em equilíbrio, a ansiedade alheia, ou sua agitação" (XAVIER, 2007: 110).

Desconfiada dos rituais macabros do beato, Rosa o assassina, acabando com a fé mística de Manuel e inserindo na trama Antônio das Mortes, que termina o serviço de dar cabo de Sebastião. Entretanto, agora é Corisco, companheiro de Lampião, que, pelo caminho da violência, vai propor a Manuel o pacto com o diabo em nome da libertação e do fim de todo o sofrimento. Outra vez Antônio das Mortes entra em ação para livrar Manuel e Rosa das garras de Corisco. Antônio das Mortes, portanto, numa leitura alegórica, tal como a feita por Ismail 
Xavier e tida como uma interpretação corrente nas leituras de outros autores a respeito de Deus e o diabo, representa o herói consciente de tudo o que deve ser destruído para que se alcance a utopia, representada simbolicamente pelo mar e profetizada ao longo de todo o filme ("O sertão vai virar mar, o mar virar sertão"). Antônio das Mortes representa, pois, o intelectual que vai forjar o caminho da revolução, apesar de não ser ele o personagem que vai efetivar essa revolução; em Deus e o diabo, "Manuel não se libera do mergulho messiânico; é liberado. Não está ainda no centro de sua própria trajetória” (Ibidem: 139).

No que concerne à construção da forma de Deus e o diabo na terra do sol, retornam as questões em torno do cinema de cunho popular, de caráter nacional e nacionalista. Mais uma vez, refazendo o movimento do intelectual em direção ao oprimido e sua cultura, Glauber oscila entre o popular em direção à classe média/artistas/intelectuais (o cordel, não como vox populi, mas com tratamento complexo e mediado pela recriação das canções, compostas por Glauber e Sérgio Ricardo, com tessitura da narrativa e comentários reelaborados) e, por outro lado, um movimento da classe média/artística/intelectuais em direção ao popular (a reelaboração do erudito a partir do popular e a conotação nacionalista de VillaLobos), sintetizando o encontro de classes em nome da mudança.

A corrida de Manuel e Rosa em direção ao mar e a saída de um esquema que estava condenado a se repetir eternamente em círculos denota a interferência intelectual de Antônio das Mortes como mentor de um projeto teleológico radical para o casal, projeto que sintetiza e alegoriza a libertação dos oprimidos no âmbito nacional. "Deus e o diabo ocupa-se do passado para caracterizá-lo como perecível, ao mesmo tempo que o dignifica como aquela travessia que torna possível a corrida em direção ao télos." (Ibidem: 139). A corrida não se mostra efetivamente como saída, visto que Manuel não encontra o mar na tela; ela antes "figura um presente que é pura indeterminação (...) A consumação do télos é um pressuposto, embora permaneça indefinida sua forma particular de realização." (Ibidem: 140). E, embora aponte mais para uma possibilidade que uma saída, o processo por inteiro indica que messianismo e cangaço prefiguram a revolução (Ibidem: 140). Alex Viany, rechaçando qualquer possibilidade de dúvida, evidencia o fechamento ideológico contido no projeto político e intelectual de Glauber Rocha: 
A conclusão não está escondida: é uma conclusão clara, quando a canção entra, violenta, no final, para dizer que a terra não é de Deus nem do Diabo, mas sim do Homem. Não é uma conclusão imposta: ela já foi exposta através do filme. No final, apenas, digamos assim, para as pessoas que não hajam ainda compreendido, a canção auxilia a tornar a coisa mais clara. (VIANY, 1999: 56)

\section{3.}

\section{O golpe militar e a crise da representação}

No período que se seguiu ao golpe militar de 1964, os mesmos cineastas que se apregoavam o papel de conduzir as massas para a revolução caíram em descrédito. A crise foi vivida na realidade e, por consequência, nos filmes. Marcelo Ridenti chama atenção para a produção literária e cinematográfica da época, cujo tema central era "o lugar do intelectual de esquerda na sociedade brasileira (...) a refletir sobre as condições impostas a eles pela modernização conservadora da sociedade sob a ditadura" (RIDENTI, 2000: 43). Era o início da crise do intelectual, que ocorreria em âmbito internacional, agonizando e se arrastando já a partir dos anos 60, com a distribuição de golpes militares pela América Latina, até o fim dos regimes socialistas, pelo mundo, no final dos anos 80. Assim, Beatriz Sarlo dirige sua mensagem ao intelectual, ao tempo em que parece também estar refletindo sobre sua própria condição:

Pensaram que estavam na vanguarda da sociedade; que eram a voz dos que não tinham voz. Acharam que podiam representar os que viviam oprimidos pela pobreza e pela ignorância, sem saber quais eram seus verdadeiros interesses ou o caminho para alcançá-los. Pensaram que as ideias podiam descer até aqueles que, operários, camponeses, marginais, submersos num mundo cego, eram vítimas de sua experiência. Sentiram-se portadores de uma promessa: obter os direitos dos que não tinham direito algum. Pensaram que sabiam mais do que as pessoas comuns e que esse saber lhes outorgava um só privilégio: comunicá-lo e, se preciso fosse, impô-lo a maiorias cuja condição social as impedia de ver com clareza e, consequentemente, trabalhar no sentido de seus interesses. (SARLO, 2004: 159)

A crise da representação, diagnosticada por Beatriz Sarlo, encontrou aqui no Brasil a ditadura militar e sua repressão sobre a produção cinematográfica, que viria gradualmente, até seu acirramento com o AI-5, em 1968. Contudo, fatores internos do Cinema Novo corroboraram para a cisão entre os cineastasintelectuais e o povo representado: em primeiro lugar, a ausência de uma política 
de distribuição dos filmes, fato bastante contraditório quando se pensava que o Cinema Novo deveria substituir o gosto das massas pelos filmes de Hollywood (a criação da distribuidora Difilm, em 1965, veio tarde e durou pouco); outro fator que colaborou para manter o afastamento entre representantes e representados foi a abordagem de conteúdos e a linguagem estética que pouco interessaram ao grande público. Ismail Xavier chama a atenção para a autocrítica no Cinema Novo, que, em conjuntura adversa, procurou estar "mais atento à comunicação, cujo nacionalismo se expressa no diálogo com a tradição cultural erudita ou com a comédia popular" (XAVIER, 2001: 58), num momento em que a postura de análise social estaria menos ansiosa por resultados imediatos, tal como ocorreu no período em que se tentou a conscientização para a luta revolucionária.

Portanto, o eixo que antes se voltava para a discussão de temas como a liberdade, a violência, a pobreza, a situação dos negros e do povo oprimido no nordeste do país, o coronelismo e o misticismo religioso, agora, buscava refletir sobre os intelectuais, que se viam demitidos de sua função. O golpe militar provocou uma ruptura nesse encaminhamento, inviabilizando o projeto original do Cinema Novo de "discutir o Brasil abertamente, enfatizando segmentos sociais sem direito a voz, com a proximidade da câmera na mão, do som direto, da ida dos cineastas aos locais onde o real seria enquadrado" (CARVALHO, 2006: 298). Assim, em 1965, Paulo César Saraceni lançava $O$ desafio, filme que "precisava ser feito para dizer ao espectador, em cada fala, que tinha havido um golpe de Estado no Brasil” (Ibidem: 300), e que narra a angústia de Marcelo, jornalista com pretensões literárias, cujo sonho precisou ser adiado por conta da impotência coletiva e existencial pela qual estava passando:

Todos os projetos concebidos, assim como a vida cotidiana, não poderiam prosseguir diante da tragédia que se abatera sobre o país. Cada personagem do filme reage ao fato de modo diferente: a mulher acredita que o amor do casal está acima da política; um colega de trabalho reconhece o fracasso da ilusão, mas aceita seguir adiante da melhor forma possível; outro, um intelectual mais velho, opta pelo cinismo; um empresário burguês sente-se aliviado, pois o perigo que cercava sua classe social fora superado. $\mathrm{O}$ atormentado jornalista era, então, o depositário do peso da derrota, do fim daquele sonho de uma sociedade mais justa, de um país mais humano. (Ibidem: 300)

Essa falta de perspectiva coletiva teve impacto maior em grande parte da esquerda e da intelectualidade brasileira. No filme de Saraceni, a ruptura entre 
Marcelo, jornalista intelectual, e sua amante Ada, mulher de um empresário da alta burguesia, foi emblemática para evidenciar a configuração de uma luta de classes, a ideia do cada um por si, num momento em que não havia mais um acordo possível e também não fazia mais sentido representações sobre o outro. $\mathrm{Na}$ falta de um projeto histórico, o próprio intelectual não sabia mais que rumo tomar, “a mudança de governo extinguiu uma ilusão eufórica e esclareceu a situação. (...) A ilusão da aliança burguesia nacionalista-classe média-proletariado pertence ao passado" (BERNARDET, 2007: 148). O intelectual, em simbiose com a sociedade, mostrava a esta um espelho estilhaçado do qual ela própria fazia parte, como esclarece Sartre:

Produto de sociedades despedaçadas, o intelectual é sua testemunha porque interiorizou seu despedaçamento. É, portanto, um produto histórico. Nesse sentido, nenhuma sociedade pode se queixar de seus intelectuais sem acusar a si mesma, pois ela só tem os que faz. (SARTRE, 1994: 31)

Em 1967, foi a vez de Glauber Rocha, com o polêmico Terra em transe, que, além da autocrítica, atirava para todos os lados, resvalando lama, inclusive, no povo, e "desagradando a grande parte da crítica especializada, bem como a vários setores da intelectualidade política do país, de direita e de esquerda" (CARVALHO, 2006: 301). Glauber passava a ver o operário como "fantoche do sindicalismo", ignorante e subdesenvolvido, e os intelectuais da classe média apareciam em defesa daqueles para transformar a situação, "mas a utopia moralista dos intelectuais 'puros' é que justamente sabota muito mais o trabalho de comunicação com o público" (GERBER, 1977: 19-20). Sintomática de uma revisão radical, a crítica para legitimar o filme veio justamente de um conservador. Cabe aqui reproduzir as opiniões de Nelson Rodrigues sobre Terra em transe, publicada em 16 de maio de 1967, no Correio da Manhã:

Durante as duas horas de projeção, não gostei de nada. Minto. Fiquei maravilhado com uma das cenas finais de Terra em Transe. Refiro-me ao momento que dão a palavra ao povo. Mandam o povo falar, e este faz uma pausa ensurdecedora. E, de repente, o filme esfrega na cara da plateia esta verdade mansa, translúcida, eterna: o povo é débil mental. Eu e o filme dizemos isso sem nenhuma crueldade. Foi sempre assim e será assim eternamente. O povo pare os gênios, e só. Depois de os parir volta a babar na gravata (...) Terra em Transe não morrera para mim (...) sentia nas minhas entranhas o seu rumor. De repente, no telefone com o Hélio Pelegrino, houve o berro simultâneo: 'Genial!' Estava certo o Gilberto Santeiro (...) Nós estávamos cegos, surdos e mudos para o óbvio. Terra em Transe era o 
Brasil. Aqueles sujeitos retorcidos em danações hediondas somos nós. Queríamos ver uma mesa bem posta, com tudo nos seus lugares, pratos, talheres e uma impressão de Manchete. Pois Glauber nos deu um vômito triunfal. Os Sertões de Euclides da Cunha também foi o Brasil vomitado. E qualquer obra de arte para ter sentido no Brasil precisa ser essa golfada hedionda. ${ }^{8}$

Como se não bastasse o mal-estar gerado na recepção, Terra em transe apresentava uma linguagem estética inovadora no cinema brasileiro (sequência em blocos, narrativa não-linear, estilos variados, movimentos de câmera caóticos, mais ligados a um filme poético do que a uma ficção), que acirrou ainda mais as divergências com os defensores de uma arte pedagógica. Voltava a questão do nacional-popular, do cinema para as massas e, em decorrência disso, do diálogo que, ao longo da década de 60, o intelectual não conseguiu estabelecer com o público. Terra em transe parecia já não mais fazer questão desse diálogo e, embora estivesse atrelado a uma ideia de cinema de vanguarda que não excluía o público, não se pode negar que sua (falta de) comunicação denotava o descontentamento e a derrota, resumidos na ironia de Beatriz Sarlo: "Escreveram para o Povo ou para a Nação; pensaram que seus escritos estavam construindo o Povo ou a Nação” (SARLO, 2004: 163).

Em o Dragão da maldade contra o santo guerreiro ${ }^{9}$, o personagem Antônio das Mortes, que possibilitou a redenção de Rosa e Manuel, em Deus e o diabo na terra do sol, percebia que o inimigo não se apresenta mais como um, mas vários e mutáveis. Misticismo e cangaço não estavam mais tão impregnados do atraso, tinham agora nuances mais complexas, ao tempo em que Antônio das Mortes, a figura que representava o intelectual que cuidou do caminho para a revolução

descobre ter lutado sempre contra o inimigo errado: em vez de ajudar o "povo" a libertar-se matando beatos e cangaceiros, ele servira ao poder dos coronéis, por desconsiderar a força da cultura popular, a única capaz de engendrar suas próprias saídas. E no personagem do sarcástico e impotente professor, representado por um Othon Bastos claramente inspirado na figura de seu diretor, estava delineada ainda uma nova postura de Glauber Rocha diante da ideia do intelectual/artista revolucionário. (CARVALHO, 2006: 305-6)

\footnotetext{
${ }^{8}$ RODRIGUES, Nelson. Correio da Manhã (16/05/1967). In: http://www.tempoglauber.com.br/glauber/Filmografia/terra.htm

${ }^{9} \mathrm{O}$ filme, no exterior, recebeu o título de Antônio das Mortes.
} 
Junto com O dragão da maldade, Os herdeiros (1969), de Carlos Diegues, que mostrou a amargura da política corroendo o caráter de uma família, foram projetos que, embora moldados e condizentes com a ressaca do golpe militar e com a crise do intelectual engajado, não se inscreviam nessa outra etapa por puro gosto dos diretores. Grande parte desses projetos já estava sendo concebido sob o regime de censura prévia. A manutenção de certo engajamento, nos casos em que ainda havia, agora passava não só pelo desafio de compreender a complexidade da cultura brasileira, vista de modo esquemático na fase anterior, mas também pela estratégia de elaborar meios de driblar a censura. Sérgio Paulo Rouanet, ao tratar em conferência sobre o silêncio dos intelectuais, afirmou que quando este se cala, "ele está simplesmente resistindo à verbalização de verdades penosas" (ROUANET, 2006: 81) e, traçando paralelo com a psicanálise, comparou a sociedade a um paciente que está num consultório de análise e se incomoda quando o analista silencia, interpretando essa atitude como menosprezo. A sociedade

está ao mesmo tempo exprimindo uma culpa inconsciente pelo parricídio que cometeu ao livrar-se do intelectual, e uma obscura nostalgia das condições tribais, em que pai primitivo acumulava as funções de rei, de sábio, e de líder religioso, ou seja, aquelas funções que mais tarde se condensariam na figura do intelectual. (Ibidem: 81)

Ainda segundo o autor, o silêncio do intelectual quase sempre se deve ao processo de radicalização da democracia (Ibidem: 76). Gostaríamos de crer nessa hipótese, mas, no Brasil, a exceção fez com que, muito frequentemente, o silêncio do artista, do intelectual, não fosse uma atitude voluntária de sua parte, mas uma imposição do poder antidemocrático. Nesse sentido, Marilena Chauí afirma que:

o verdadeiro silêncio dos intelectuais não tem como origem o fortalecimento da cidadania e da participação, mas a mudança na forma de inserção das artes e do saber no modo de produção capitalista e o refluxo do pensamento de esquerda ou da ideia revolucionária de emancipação do gênero humano. (CHAUÍ, 2006: 41)

Sem dúvida, a perda de utopia e da ideia de emancipação pela revolução, atropelada pelo golpe militar, quando não colocou a esquerda intelectual em silêncio, fez com que os artistas criassem mecanismos de sobrevivência. Assim, vemos parte da produção cinematográfica de início dos anos 70 aproveitando-se 
da brecha do governo militar quando este passou a incentivar a produção de filmes históricos a fim de estimular o nacionalismo entre os brasileiros. Em Os inconfidentes (1971), de Joaquim Pedro de Andrade, o que seria um filme histórico-institucional para resgatar o orgulho nacional apareceu como crítica ao regime, ao promover, pela trajetória de Tiradentes, a alegoria que igualava e unia passado e presente. No mesmo diapasão de crítica aos intelectuais, Os inconfidentes, entretanto, chamava a atenção para a separação entre Tiradentes e os demais conjurados,

sendo o primeiro o representante de uma postura que diante do mundo se afirma pelo 'sentido prático', pelo 'querer fazer', enquanto os outros são os representantes de um posicionamento 'especulativo' em que a 'discussão' assume o papel central. (...) o 'sentido prático/querer fazer' visa diretamente à revolução, ao passo que a 'especulação/discussão' parece querer indicar que a revolução teria saído do horizonte. (...) Intelectuais são os que especulam/discutem. Os nãointelectuais são aqueles que querem fazer/têm sentido prático. (RAMOS, 2002: 69)

Poderíamos inserir, aqui, a querela entre Sartre e Merleau-Ponty: em 1953, preocupado com a resposta minguada dos trabalhadores ao Partido Comunista Francês, quando este os convocou para uma manifestação contra a Guerra da Coreia e contra a prisão do secretário-geral do partido, Sartre escreve artigo para a revista LesTempsModernes, propondo que todas as esquerdas se unissem toda vez que um partido comunista fosse atacado. Ainda no mesmo artigo, Sartre conclama os trabalhadores a se organizarem num partido revolucionário, porque "sendo o Partido Comunista tal partido, sem ele os operários não existirão como classe, mas apenas como massa passiva e alienada" (CHAUÍ, 2006: 21). A reação de MerleauPonty, logo em seguida, na mesma revista, é a de se colocar contra o posicionamento de Sartre a respeito do engajamento de operários no Partido Comunista. Argumenta ele que, com a "crise atual da ideia de revolução, a ideia de Marx do desenvolvimento da consciência de classe foi substituída pela ideia bolchevique de "interesses do partido" (Ibidem: 21). Reflexo dessa opinião divergente, Merleau-Ponty parecia propor uma filosofia estanque da realidade, reconhecendo "as difíceis relações entre o filósofo e a Cidade". Sartre, por sua vez, propunha na sua clássica frase "uma filosofia que se interesse pelos homens reais, com seus trabalhos e suas penas". 
Tenhamos em vista, também, que o engajamento do qual falam os filósofos fez parte da vida de Sartre e foi esse, para ele, o ideal de intelectual, assim como foi este o conceito de intelectual que guiou os cineastas intelectuais do Cinema Novo e orientou nosso trabalho. Embora nem sempre estivessem filiados a partidos, os cineastas estavam comprometidos politicamente com o destino da nação e tinham sempre em mente a intervenção pública e o sonho de deflagração da revolução nas consciências, sentimento que os filia mais ao sentido prático que ao especulativo.

Haja vista que na série de filmes que pensaram o intelectual, $O s$ inconfidentes apareceu, na sequência, não só para refletir sobre os rumos equivocados que percorreram os conjurados, mas também sobre o dilema do fazer e pensar (Sartre-Merleau-Ponty): o que atravessou o filme foi a urgência de ação. Dos discursos, algumas vezes didáticos, que não faziam mais sentido, "a indagação básica, no pós-1964, era: o que fazer? E não o que dizer... Dizer e fazer eram entendidos como pertencendo a campos muito distintos" (RAMOS, 2002: 124). Assim sendo, a crítica de Joaquim Pedro pareceu inscrever ao lado de Tiradentes os diretores do Cinema Novo, que lutaram por uma causa, ainda que o personagem, "combativo militante", trouxesse consigo a mancha da derrota, "sem sucesso em sua empreitada junto às camadas sociais oprimidas" e lutasse "em nome de interesses coletivos/populares", sendo, ao mesmo tempo, "profundamente marcado pelos valores das classes dominantes" (Ibidem: 265).

A ambiguidade de Tiradentes, apontada muitas vezes na intrincada relação classe média-intelectuais-povo (popular-classe dominante) e suscitadora da desconfiança de ambos os lados, nos remete novamente a Sartre e ao eterno conflito do lugar do intelectual na sociedade. Todavia, mesmo inerente a esse deslocamento contínuo, Tiradentes estaria posicionado de modo diferente em relação a seus companheiros. Para Freire Ramos, há uma clara distinção entre o "sentido prático" do "querer fazer" do Alferes e o "posicionamento 'especulativo" dos demais companheiros, "em que a 'discussão' assume o papel central" (RAMOS, 2002: 308). Por conseguinte, Freire Ramos reivindica para Tiradentes, frente a seus companheiros, a marca do intelectual: "entre um e outro modo de se inserir no mundo, estabelecia-se uma rígida escala de valores, orientada obviamente pelo seu presente: um é o polo positivo, o outro é o negativo" (Ibidem: 308). O sentido prático de Tiradentes, portanto, "visa 
diretamente à revolução, ao passo que a especulação/discussão parece querer indicar que a revolução teria saído do horizonte" (Ibidem: 308).

E é justamente no polo negativo, no distanciamento intelectual-povo, que os filmes pós-64 se pautaram ( $O$ desafio, Terra em transe, Fome de amor, 1967, de Nelson Pereira dos Santos, e O bravo guerreiro, 1968, de Gustavo Dahl). No caso de Os inconfidentes, a proposição estética do filme revela o ambiente fantasmagórico, onde "os (pouco) personagens circulam por espaços interiores fechados (salas de estar, quartos, salões vazios, cela de prisão, etc)" (Ibidem: 100). Freire Ramos, analisando outro recurso estético, chama a atenção para a construção do ponto de vista, que, ao fazer o personagem dirigir sua confissão para a câmera, interpela o espectador e solicita a este uma ressonância do discurso em seu presente. (Ibidem: 71).

Freire Ramos lembra ainda (Ibidem: 78) o breve período em que Joaquim Pedro esteve preso em decorrência de um protesto feito em novembro de 1965, em frente ao hotel Glória, no Rio de Janeiro, quando Castelo Branco chegava para presidir a abertura de uma conferência da OEA. Na prisão, que durou uma semana, Joaquim Pedro amadureceu o projeto de filmar a história de Tiradentes, numa forte alusão ao momento da cadeia. Coincidindo com o ano de lançamento do filme, outro ponto bastante marcante na leitura alegórica foi o declínio da ação dos guerrilheiros urbanos em virtude da forte repressão que a esquerda vivia como o extermínio de seus integrantes pela ditadura militar (Ibidem: 303). Tiradentes apresentava-se, assim, como herói derrotado, mas que, como muitos guerrilheiros, lutaram até quando puderam.

\section{4 .}

\section{Da sobrevivência do intelectual à virada antropológica}

Fazendo uma revisão crítica, ao discorrerem sobre as derrotas da esquerda e a suposta falência do projeto utópico, os intelectuais abriram caminho para o relativismo. Tal movimento levou Norberto Bobbio a destacar a substituição de um intelectual utopista, que queria mudar o mundo, por um intelectual realista, afirmando que "caiu em descrédito o intelectual utopista que gostaria de mudar o mundo à sua imagem e semelhança" (BOBBIO, 1997: 14). Por outro viés, Vera 
Follain de Figueiredo parte de algumas propostas revisionistas do filósofo grego Cornelius Castoriadis para pensar os impasses do intelectual hoje. A preocupação com a identificação das raízes do totalitarismo que minou o sonho das esquerdas caracterizou a reflexão de Castoriadis sobre o papel do intelectual. Para o filósofo, o cristianismo forneceu durante séculos as condições exigidas para a aceitação do "real" tal qual ele é, até a apoteose literal do sistema hegeliano, de que o marxismo, em parte, seria herdeiro. Apesar das aparências, cristianismo e hegelianismo seriam o mesmo universo - teológico, acrítico, apolítico. (FIGUEIREDO, 2004: 134).

Para reinstituir a tarefa autêntica do intelectual na história, Castoriadis propõe, então, a restauração da função crítica do intelectual, contanto que este se coloque "a distância do cotidiano e do real e a distância também, o mais possível, de si próprio" (Ibidem: 134). Como observou Vera Follain de Figueiredo, preocupado com o dogmatismo que pode derivar do fato do intelectual se considerar detentor da verdade, mas sem querer abrir mão dos valores universais, Castoriadis destaca a necessidade do reconhecimento dos limites da objetividade e da universalidade. Diante deste argumento, Figueiredo pergunta que razão seria essa que faria do intelectual um ser supra-histórico, situado numa espécie de nãolugar que garantiria a objetividade. Indaga também o que seriam exatamente esses limites da objetividade e se uma verdade tida de antemão como relativizável valeria o risco inerente a todo envolvimento numa causa (FIGUEIREDO, 2004: 134). A autora conclui que a confiança na função crítica do intelectual, como porta-voz da objetividade, que Castoriadis quer restaurar, só seria restituída, caso se recuperasse a confiança em valores universais, isto é, caso se conseguisse pensar a universalidade num outro diapasão - não mais aquela "universalidade" etnocêntrica que serviu de base ideológica para justificar o colonialismo. (Ibidem: $135)$.

Quando se trata de pensar a manutenção do papel crítico do intelectual, é importante também lembrar ainda o argumento da ensaísta argentina Beatriz Sarlo, ao considerar que, dada a continuidade das desigualdades e da injustiça social,

a função crítica desempenhada pelos intelectuais e pelas vanguardas, entre suas outras funções, ainda exerce um apelo poderoso, porque não se desvaneceram as 
injustiças que deram impulso ao fogo cerrado entre poderes absolutos e legitimidades baseadas na autoridade despótica e na concentração de riquezas. As sociedades que surgem da modernidade tardia estão longe de realizar um ideal igualitarista e democrático. (SARLO, 2004: 164)

A suspeita sobre o intelectual e sua legitimidade para falar pelo outro atingiu, nos anos 1970, o cinema brasileiro. Levado a reboque num movimento bem mais abrangente, cujo deslocamento operou no sentido de dar voz ao outro, muitos cineastas empreenderam a tarefa de tentar ouvir o que o outro tinha a dizer, já que a sua própria fala não chegou a este outro e tampouco levou à revolução. Assim, Glauber Rocha, em uma entrevista de 1980, declarou-se perseguido pela elite, que se apropria de toda a arte revolucionária ("quem ouve Villa-Lobos é a elite, a burguesia brasileira culta. Quem tem quadro de Portinari, quem lê João Cabral, Guimarães Rosa não é o povo"), sem criar meios para que a arte revolucionária, "sequestrada pela classe dominante e censurada" 10 , chegue ao povo. Ciente da domesticação pela qual passara a arte revolucionária e diante de sua derrota como intelectual utópico, na mesma entrevista, Glauber, baluarte do pensamento da esquerda iluminista dentro do Cinema Novo, afirmou estar "metido", desde suas origens

numa batalha que é a dessacralização do artista e do intelectual. Inclusive, eu não estou de acordo com a representação que se fazem os intelectuais, os artistas no centro da sociedade. Não estou de acordo com nada disso. Acho que o artista tende a se prostituir, no Brasil, rapidamente, e os outros intelectuais já se acomodaram. $^{11}$

Diferente da opinião extremada de Glauber, proferida num momento de grande impasse, para quem o artista e o intelectual eram sagrados e precisavam sair desse pedestal, o projeto, cujo centro e o objetivo eram não o cineasta intelectual - sendo este apenas o agente deflagrador - mas a libertação da nação, foi sendo minado diante do contexto de relativizações que puseram em xeque a Verdade e a Justiça, até então universais. Não sem gerar problemas ideológicos, o discurso sobre entrava em desuso para dar lugar ao discurso de. Ismail Xavier alude a uma postura geral de "levantar poeira dos arquivos, abrir os olhos do observador; uma vontade maior de empirismo, de ver e ouvir os segmentos da

10 Entrevista com Glauber Rocha (1980) - Patrulhas Ideológicas. In: GASPARI, Elio, HOLLANDA, Heloísa Buarque, VENTURA, Zuenir. 70/80 Cultura em trânsito: da repressão à abertura. Rio de Janeiro: Aeroplano, 2000.

${ }^{11}$ Idem, p.34 
população, as testemunhas dos processos, os agentes históricos, os porta-vozes de comunidades" (XAVIER, 2001: 89). Ainda segundo o autor, em termos gerais, o que separou as décadas foi a mudança na abordagem da matéria real:

a década de 60 , no seu conjunto, corresponderia ao momento do que se poderia chamar 'crítica dialética' da cultura popular, marcada pela presença da categoria da alienação no centro de sua abordagem da consciência das classes dominadas; a década de 70 corresponderia a um gradativo deslocamento pelo esforço de 'compreensão antropológica', tornada possível através de um recuo do cineasta, que resolve pôr entre parênteses seus valores - em alguns casos, a visão marxista do processo social e da ideologia - e renuncia à ideia da religiosidade popular como alienação. Abre-se espaço para uma política de adesão que privilegia, nas representações dadas, uma positividade quase absoluta, que as torna intocáveis porque testemunho da resistência cultural frente à dominação e afirmação essencial da identidade. (Idem, 2007: 25)

Além da mudança que privilegiou o enfoque concentrado no cotidiano e no homem comum, não mais para olhá-lo com a lente iluminista-marxista, mas para ouvir a sua voz, sem emitir juízo crítico, a nova abordagem precisou de outras ferramentas para lidar com o avanço da indústria cultural ou para se ver derrotada por e diante dela. Nessa onda, muitos intelectuais migraram para a televisão, na vã esperança de que lá poderiam fazer a revolução. Com isso, a eterna busca do popular-nacional foi encerrada simbolicamente no nostálgico adeus, dado no último ano da década de 70, com Bye bye Brasil, de Carlos Diegues. No filme, a caravana Rolidei entrava Brasil adentro para divertir o povo brasileiro com os espetáculos circenses e de lá voltava, decepcionada e desafiada, por conta de uma nova máquina de fazer imagens. 


\section{3}

\section{A política da voz do outro}

A identidade dos sujeitos voltou a tomar o lugar ocupado, nos anos 1960, pelas estruturas.

Beatriz Sarlo

\section{1.}

Impasses do falar pelo outro no documentário brasileiro moderno

Neste capítulo, empreenderemos um recuo histórico, começando por enfocar algumas questões do documentário brasileiro dos anos 60 e 70 empreendimento que, à primeira vista, poderá se revelar um tour de force, mas esclareceremos o porquê da ênfase na abordagem dos documentários em detrimento da ficção, dado o fato de que nosso foco está, sobretudo, voltado para esta última. Desde já, entretanto, cabe ressaltar, como muitas vezes já se tem feito, os inúmeros pontos de interseção entre o campo da ficção e o do documentário. A título de exemplo, pensemos nas inovações tecnológicas utilizadas pelo cinema diretoe que logo foram absorvidas pela ficção na onda de cinemas novos em todo o mundo, principalmente pela nouvelle vague.

No mais, cabe também acrescentar as mudanças macropolíticas e sócioculturais que extrapolam o cinema - como o momento da virada antropológica em detrimento de uma visada marxista - e que afetam a produção cultural concomitantemente, com um grau de avanço no tempo mais ou menos parecido, obedecendo ao que se costuma chamar de "tendências". "Nacionalismo, política de identidade, diáspora e exílio não surgem com o documentário", como afirma Bill Nichols. O mesmo autor, ao definir os modos de abordagem do documentário em relação ao real, afirma que cada um desses modos por ele estabelecido "pode surgir, em parte, como reação às limitações percebidas em outros modos, como reação às possibilidades tecnológicas e como reação a um contexto social em mudança." (NICHOLS, 2005: 63). 
Nesse sentido, devem-se somar, com ênfase e em pé de igualdade, não só o contexto em que os filmes foram produzidos, mas também o surgimento de novas possibilidades de abordagem, como as propiciadas, por exemplo, pela captura do som direto. Pois nem sempre o "documentário sociológico" - denominação que Jean-Claude Bernardet dá aos documentários cuja principal estratégia narrativa é o farto uso da locução em off - agiu de má fé quando esteve naquela posição acossada com meios limitados de representação. Não obstante, caberá aqui recuperar a recepção crítica dos documentários surgidos em meados nos anos 1960 e ao longo da década de 1970, num breve panorama que dará, sobretudo, ênfase à leitura apurada de Bernardet, à abordagem contemporânea que Fernão Ramos faz do cinema direto e sua recepção no Brasil e às teorias do documentário expostas por Bill Nichols, para, em seguida, discutir algumas questões críticas.

Neste capítulo, nossa opção foi menos a de analisar filmes e mais a de pensar as questões que estes autores levantam, com especial atenção para as recepções negativas que colocam em terreno instável a "voz do saber" e, de certo modo, orientam novas metodologias praticadas no cinema brasileiro contemporâneo (documentário e ficção). Ainda sobre este capítulo, vale adiantar que nossa atenção recai na política de "dar voz ao outro", estratégia cinematográfica estimulada por indagações oriundas do campo da antropologia e que grosso modo custou ao Cinema Novo seu definhamento. Depostas a voz do intelectual e a voz de Deus, cineastas e intelectuais ora recusaram-se a aceitar a deposição, ora pensaram novas formas de representação, aplicando-as à sua maneira. Poucos foram os que admitiram a impossibilidade de narrar pelo outro, como fez Arthur Omar no curta-metragem Congo (1972), cujo teor consiste em “cerca de 148 planos, dos quais 124 são letreiros, letras pretas, fundo branco (...) Apenas 24 planos são filmados ao vivo, nenhum deles porém ilustrando a congada" (BERNARDET, 2005: 295).

À primeira formulação - a dos intelectuais que buscaram protelar sua função de representante da sociedade sem voz - consola a concepção sartreana de intelectual como sujeito que sofreria de um contínuo e inerente deslocamento entre as classes, em face da sua dificuldade de inserção no povo, de plena identificação com as camadas populares. Por outro lado, o deslocamento viria também da improvável acomodação do intelectual na classe média, lugar de repulsa recíproca, visto que o intelectual não desejava ser identificado como 
classe média e esta via com desconfiança o intelectual de esquerda sempre a atacar os valores e o status quo burgueses. Era ao povo que o intelectual desejava estar associado, mas, como Sartre, Jean-Claude Bernardet aponta essa impossibilidade, justificada através dos modos distintos de apreender os valores culturais. "É através de nossas palavras sociológicas ou antropológicas emitidas nas cidades e nos livros que entramos em contato com formas da cultura popular, rural, tradicional". Não seria através de uma vivência produtiva, e ainda que este intelectual se aproximasse de manifestações culturais populares, por mais que ele tendesse a "aspirar por osmose essa tradição cultural" sua formação não deixaria de estar baseada nos livros e na cidade. Na tentativa de superar essa distância (cultural e de classes), falou mais alto ao intelectual o "projeto de memória nacional [que] nega em nome da unidade nacional" (Ibidem: 296). Deste modo, permanecia ainda o diapasão de pensar o cinema como meio de conscientização que levaria à revolução, negando as divergências culturais em nome da unidade nacional.

Outro ponto criticado na abordagem do povo pelo diretor intelectual diz respeito a uma adesão parcial em relação à cultura popular. Ainda que, de modo geral, esse povo não visse o intelectual como um de seus pares, e este intelectual buscasse talvez sua fusão com o popular, o mesmo intelectual, em nome da razão, julgava alienantes manifestações da cultura popular. Na ficção, por exemplo, Barravento, de Glauber Rocha, buscou a conscientização do público, usando a religião como contra-exemplo e negando o esoterismo desta pelas vias da razão iluminista, prerrogativa para o alcance do progresso social. No documentário, quando quis exemplificar a alienação, o cinema fez uso de temas caros ao grande público. Assim, vemos um filme como Garrincha, alegria do povo (1963), de Joaquim Pedro de Andrade, onde, à revelia do título, o foco recai sobre o futebol como instrumento de manipulação política e "quando as abordagens particulares se apresentam, elas estão a serviço da representação condensada no todo, mesmo quando o indivíduo seja Garrincha" (HOLANDA, 2006: 3).

Como salientou Bernardet, na primeira metade dos anos 60, uma convergência de pensamento entre ISEB (Instituto Superior de Estudos Brasileiros), CPC (Centro Popular de Cultura) e Cinema Novo trabalhou com a dobradinha consciência/alienação. A ação transformadora viria pela consciência e 
o povo, que tinha aspirações, mas era alienado, não conheceria os meios para a revolução:

Compete a quem tiver condições captar as aspirações populares, elaborá-las sob forma de conhecimento da situação do país e reconhecimento dessas aspirações, devolvê-las então ao povo, gerando assim consciência nele. E quem tem condição de efetuar essa operação são os intelectuais. A posição social do intelectual sensível às aspirações latentes do povo lhe permite ser gerador de consciência. (...) Desse modo, a apresentação do povo como alienado explica o doloroso golpe de 64 e justifica os intelectuais, entre os quais os cineastas. A justificativa da existência do intelectual, nesse quadro, é a alienação do povo. (BERNARDET, 2003: 34)

No pós-golpe, Viramundo(1965), de Geraldo Sarno, formulava uma pergunta latente sobre a ausência de resistência popular ao golpe: "Por que o golpe de Estado (...) ocorreu sem resistência popular significativa, quando intelectuais e líderes políticos pensavam que o povo estava mobilizado num sentido revolucionário?", no que Viramundo responderia: “eis a situação da classe operária, ou pelo menos do contingente nordestino da classe operária paulista. (...) Ela não tem como se afirmar, se mobilizar, só se resolve na alienação" (BERNARDET, 2003: 33)

No extremo oposto, foi ao lado do povo que o cineasta se colocou quando precisou apontar sua artilharia para a classe média. Se no contexto pré-golpe a classe média era coautora no projeto revolucionário - projeto que não excluía a burguesia, ao passo que o que se enxergava como o inimigo, como o outro a ser combatido, era o imperialismo norte-americano -, no período pós-golpe, a lupa de diretores do Cinema Novo para a busca dos erros continuou focada na alienação do povo, mas, na alça de mira dos intelectuais estava, cada vez mais, a classe média, agravando-se uma relação que já era conflituosa para ambas as partes.

Ainda em Viramundo, a elite, aquela que sempre teve o poder de narrar, é colocada estrategicamente como vilã do próprio discurso, quando o empresário entrevistado, identificado por Bernardet como aliado do locutor, "a quem o próprio realizador emprestou a voz", responde a um movimento de simpatia/antipatia. Ora o empresário é trazido pelo diretor para compor o discurso do filme, ora é tratado com fina ironia por "Senhor empresário", "há uma tensão entre a aliança feita com o empresário, no sistema de informação do filme, e o tratamento dado ao personagem, que é de rejeição" (Ibidem: 38). Segundo o autor, 
a tensão estabelecida revela, na atração realizador-empresário, uma postura contraditória para o realizador, que tem interesse na defesa dos oprimidos, mas que no modo sociológico estabelece uma relação sujeito-objeto com esse oprimido: sua "atitude sociológica, por implicar, no plano do saber, uma relação de dominação sujeito do saber/objeto do estudo, o empurra para o lado do empresário, quando o que ele quer é justamente ir do outro lado". A crítica de Bernardet consiste também em mostrar que o filme explora sua matéria-prima (o povo) da mesma forma que este é explorado pelo sistema social injusto, de modo que este povo é o meio para que o cineasta coloque em evidência o seu "discurso do saber" (Ibidem: 39). Em que pesem as críticas a este tipo de discurso, Bernardet recupera via Lenin a dimensão utópica imiscuída no falar pelo outro:

(...) para Lenin, a consciência revolucionária, a compreensão global da sociedade e as perspectivas políticas não nascem espontaneamente na classe operária. Numa frase célebre, ele afirma que a consciência revolucionária só pode chegar aos operários de fora. Ele aprova Kautski quando escreve que "a consciência socialista de hoje não pode surgir senão à base de um profundo conhecimento científico [...]. Ora, o portador da ciência não é proletariado, mas os intelectuais burgueses". Mas a consciência teórica do intelectual revolucionário se complementa ao encontrar o proletariado, sem o qual ele fica girando no vazio; por sua vez, o proletariado não consegue escapar ao espontaneísmo, aos movimentos reivindicatórios e à ideologia burguesa se não for como que fecundado pela consciência teórica do intelectual. Esse me parece ser um dos modelos sobre os quais se apoia, de modo geral, o documentário sociológico que se desenvolve no Brasil a partir da década de 1960. (Ibidem: 260)

A noção de voz, portanto, não se restringe a "um código ou característica, como o diálogo ou o comentário narrado", ela transmite o ponto de vista social, ela fala e organiza o material que oferece ao espectador e "talvez seja algo semelhante àquele padrão inatingível, formado pela interação de todos os códigos de um filme, e se aplica a todos os tipos de documentário" (NICHOLS, 2005b: 50). Decorre daí a crítica à voz de deus, esclarecido que a voz não se resume a uma fala, mas ao modo de ver o mundo. A voz de deus, identificada como a voz do locutor que narra o filme, é límpida e isenta de ruídos e isso se deve à ausência do som direto neste momento do cinema brasileiro, o que obrigou o diretor e sua equipe a fazerem em estúdio todo o tipo de gravação de áudio. Entretanto, traduzida em termos ideológicos, essa voz límpida está a favor de um sistema e de um aparelho conceitual que visa a "limpeza do real". Daí, como "não somos informados sobre essa operação de limpeza do real, temos diante de nós um 
sistema que funciona perfeitamente, em que geral e particular se completam, se apoiam, se expressam reciprocamente" (BERNARDET, 2003: 19). De acordo com Bernardet, essa voz do locutor, que flui e está livre das influências do real,

é uma voz única, enquanto os entrevistados são muitos. Voz de estúdio, sua prosódia é regular e homogênea, não há ruídos ambientes, suas frases obedecem à gramática e enquadram-se na norma culta. Outra característica: o emissor dessa voz nunca é visto na imagem. Ele pertence a um outro universo sonoro e visual, mas um universo não especificado, uma voz off cujo dono não se identifica. Diferentemente dos entrevistados, nada lhe é perguntado, fala espontaneamente e nunca de si, mas dos outros. (Ibidem: 16)

No mais, tudo o que vem além dessa voz e aparece como matéria do filme (as imagens e os sons), não a contradiz, mas, ao contrário, confirma o saber sociológico do diretor. Este, através da voz do locutor, emite sua sentença e os entrevistados "funcionam como uma amostragem que exemplifica a fala do locutor e que atesta que seu discurso é baseado no real" (Ibidem: 18). Numa estratégica e robusta conjunção entre narrar e mostrar (o outro), a veracidade do discurso se dá pelas imagens, prova real que corrobora a autenticidade do discurso, "um comentário que não será outra coisa senão a reaparição, palavra por palavra, daquilo que ele comenta" (FOUCAULT, 2007: 23).

$\mathrm{O}$ argumento do modelo sociológico está, acima de tudo, fundamentado na criação de tipos e para isso precisa desconsiderar no outro as características que o tornariam particular, individualizado, fora dos tipos pré-estabelecidos. Esse olhar "generalizante" se dá, sobretudo, por conta de uma perspectiva de fora, de terceira pessoa, que separa o sujeito do objeto a ser narrado, que "implica uma separação entre aquele que fala e aquele de quem se fala", favorecendo ao público uma visão simples, porém achatada, a partir da "sensação de que as pessoas no filme estão lá para nosso exame e edificação" (NICHOLS, 2005: 42). Quando não isso, o chamado documentário sociológico parece flexibilizar sua metodologia, mas os resultados obtidos são semelhantes. É o caso de um trecho do já citado Viramundo, em que se dá a apreensão de um relato em primeira pessoa de um dos entrevistados e a transformação desse relato em discurso; a canção que o personagem canta e que o filmereconfigura para ilustrar o próprio personagem e adequá-lo mais uma vez a um tipo. "A canção é escrita em primeira pessoa, como as entrevistas, diferentemente da locução. A origem do Viramundo, a primeira 
pessoa são elementos de aproximação, de empatia para com os migrantes" (BERNARDET, 2003: 20).

Ainda: o modelo sociológico não está passível de discussão. O que deve ser discutida é a realidade que ele aborda, mas não o processo de elaboração desta. Sobre Viramundo, Bernardet o analisa e emite um julgamento a respeito dessa linguagem:

As formas circulares, a concatenação das sequências, as montagens paralelas fazem de Viramundo um filme fortemente amarrado, sem quebras, sem brechas, sem interstícios. Acompanhamos o filme como um fluxo ininterrupto de imagens, sons e ideias. Essa coesão interna tem uma função: ela não nos dá folga. $\mathrm{O}$ filme assume uma atitude afirmativa e não se oferece, nem às suas ideias, como tema de discussão. (...) A linguagem de Viramundo não tem dúvidas de que é a expressão do real, não se coloca como uma representação ou como uma elaboração particular sobre o real. (...) Essa coesão se substitui e é aceita pelo espectador como a própria coerência do real, de forma que não haveria nem o que discutir no filme, já que coincide com o real. Só o real, o tema do filme, poderia ser discutido. (Ibidem: 32)

Do mesmo modo, o discurso do intelectual gerou estranhamento quando se interpôs em momentos calorosos intra-classe. No caso de Greve (1979), de João Batista de Andrade, filme que aborda a greve dos metalúrgicos de São Bernardo, em 1979, a estratégia consiste em inserir o fato num contexto maior, "num quadro mais amplo que os explicaria ou justificaria" (posse do novo presidente da República, política salarial, atuação das multinacionais e as condições de vida dos operários), atribuindo a esses fatos "uma certa exemplaridade" (Ibidem:187). Um filme sobre a greve, mas não feito de dentro da greve, cujo vocabulário, "essas referências políticas, que nos são familiares, só aparecem na locução e nunca em conversas, entrevistas ou discursos de operários ou líderes sindicais registrados pelo filme." (Ibidem: 193). O mal-estar gerado por essa fala de fora, reflete, de certo modo, nas palavras do Lula sindicalista e representante daquela classe: " $\mathrm{Eu}$ acho que ninguém tem o direito de vir aqui e confundir nossa luta com luta política”.

Em sentido oposto, ou de adesão mais clara ao cineasta, em Watsonvilleonstrike (1989), de Jon Silver, filme sobre uma greve de lavradores na cidade costeira de Watsonville, na Califórnia, o confronto entre intelectualcineasta e dirigente sindical dá ganho de causa ao primeiro. Neste filme, quando o diretor do sindicato ameaça expulsar Jon Silver do saguão, "o cineasta reage com 
uma panorâmica na direção dos trabalhadores mexicanos que assistem à cena $\mathrm{e}$ com uma pergunta dirigida a eles em espanhol, e não no inglês que usa com o diretor [do sindicato] americano: 'O que é que vocês acham? Tenho direito de filmar?"” (NICHOLS, 2005: 75). Para Bill Nichols,

o registro dessas perguntas e da resposta entusiasmada dos trabalhadores, tudo no mesmo plano da recusa intransigente do diretor a conceder permissão, atesta o desejo de Silver de apresentar-se como ativista franco e honesto, cuja lealdade espontânea está com os trabalhadores e não com os representantes sindicais. (Ibidem: 75)

De outro modo, agindo com repulsa em relação ao representado, Arnaldo Jabor fez em 1966 A opinião pública, em mais um movimento do cinema de tentar entender os porquês do golpe de 1964 e do marasmo em que se encontrava a sociedade frente aos problemas políticos pelos quais o país passava. Aqui, em conflito com a ideologia do cinema direto, já utilizado neste filme, o registro sincrônico de som e imagem tem pouco apelo e responde de modo diverso ao intuito político de diretores do direto nos Estados Unidos e na França, fazendo com que as conversas registradas por Jabor e explicitadas inadvertidamente por uma classe média alienada e alienante reforcem e sejam submetidas ao discurso da voz em off. Numa estratégia para fugir do "espelho que perturba o método" síntese de Bernardet para o intelectual oriundo de classe média que corre o risco de ser identificado com aquela classe média de A opinião pública - Jabor provoca um deslocamento que o tira da classe média e o põe em identificação com o outro de classe: "O 'nós' do início do filme - 'representantes da vida de cada um de nós, de nosso drama mais geral' - se transformará a seguir numa conveniente terceira pessoa", em movimento simultâneo de aproximação e rejeição da classe média (BERNARDET, 2003: 67). Bernardet infere que, dado o esgarçamento e o insucesso das tentativas de conscientização das classes pelo intelectual, num contexto de violência crescente e exacerbada, principalmente a partir de 1968, esse intelectual, por vezes, viu-se devolvido à sua classe, embora sua atitude tenha sido sempre a de negar tal pertencimento e simultaneamente afirmar seu lugar de ação social. A opinião pública reforça esse argumento e denota uma reaproximação do intelectual ao outro de classe nos demais filmes. "Há nesses filmes não só um interesse social por aqueles que são praticamente excluídos da 
sociedade e vivem na miséria, mas há também uma ternura, uma emoção cheia de dignidade, uma compaixão sincera e comovente" (Ibidem: 213).

Da década de 1980, outros dois filmes, também analisados por Bernardet, nos permitem ver, quando não um sentimento nostálgico do intelectual ainda ligado aos projetos utópicos do Cinema Novo (caso de Memórias do cárcere, de Nelson Pereira dos Santos), um outro tipo de intelectual fundido ao povo, não mais o que aborda o outro de classe (O homem que virou suco, de João Batista de Andrade). No primeiro, o intelectual que expressa o povo sem voz em cenasíntese, em que folhetos são distribuídos entre os presos, que os escondem em suas roupas, como ressalta Bernardet:

o povo - simbolizado pela comunidade dos presos - assume a obra do intelectual e, no mesmo movimento, o escritor entrega sua obra ao povo; diante da repressão a obra espalha-se e se atomiza em mil pedacinhos e, no mesmo movimento, encontra sua unidade ao fundir-se com o povo (Ibidem: 237).

Em O homem que virou suco, o poeta Deraldo - sintomaticamente interpretado por José Dumont, ator que se alfabetizou sozinho através de cordéis, contrastando, portanto, com o intelectual classe média carioca -, com todas as suas contradições, é o intelectual mais ligado ao povo, senão originado dele. Numa das sequências, Deraldo é o homem letrado que lê e escreve as cartas familiares para os operários analfabetos. Permanece aqui a angústia do cineasta e sua busca/identificação com o operário, busca enfatizada também no personagem Severino, o duplo de Deraldo, operário acusado de assassinar o patrão.

\section{2.}

A utopia do cinema direto: para acabar com o julgamento [da voz] de Deus

Sobre a chegada do cinema direto no Brasil - aparato técnico que permitiu a gravação sincronizada de imagem e áudio in loco - não se pode dizer que sua implementação se deu de forma integral aqui, tanto no que diz respeito à precariedade dos equipamentos, se falamos na adequação ao direto, quanto no que tange às ideologias que o direto norte-americano propunha e o modo diverso 
como tudo isso foi assimilado pelos cineastas brasileiros, num primeiro momento. O direto representou a possibilidade de uma nova abordagem do real, mas significou também uma mudança metodológica. Embora se pense no "modelo sociológico" como algo institucionalizado entre esses cineastas, conclusão talvez dos mais críticos quanto ao modelo, a mudança do método não sofreu resistência. Antes, cineastas que utilizaram a "voz de Deus" estavam abertos às novas possibilidades do som direto. É preciso ressaltar que havia menos resistência dos cineastas e mais da linguagem cinematográfica do "modelo sociológico". JeanClaude Bernardet defende que não eram os cineastas que não intencionavam buscar o outro, fazê-lo emergir, era a linguagem que impedia. Segundo ele, "essa linguagem que pressupõe uma fonte única do discurso, uma avaliação do outro da qual este não participa, uma organização da montagem, das ideias, dos fatos que tende a excluir a ambiguidade, essa linguagem impede a emergência do outro" (BERNARDET, 2003: 214). Por outro lado, ao falar de linguagem, o autor poderia estar remetendo a um modo de narrar o mundo que fosse condizente com o modo de pensar o mundo.

Pouco da ideologia do cinema direto norte-americano estava contida no entusiasmo dos diretores brasileiros. $\mathrm{O}$ real que buscavam antes seria o mesmo real que desejariam abarcar com a nova tecnologia, era só uma questão de mudança de método. O que ocorre é que o real do cinema direto euryankee, síntese de Glauber para o cinema verdade francês e o norte-americano, tinha como prerrogativa a busca do "real puro", seu mais caro tema, independente do que abordava. Numa opinião de David Neves -um dos expoentes e líder afetivo do Cinema Novo - sobre Integração Racial, de Paulo Cezar Saraceni, filme que fez uso de recursos do direto, está embutida a mudança de postura, que deixa de ser científica e passa a crer se não no real puro, na aproximação dele, quando promove a aproximação com o objeto filmado: "A obrigação da intimidade era uma delas [das teorias] (...) o realizador faz indagações geograficamente diferentes e na montagem as ordena de acordo com uma atmosfera psicológica previamente estudada". Mais adiante, ainda sobre o mesmo filme, a constatação da perda de terreno do olhar científico: "Como rigor científico, dirão os mais exigentes, o filme deixa a desejar, mas, retrata com fidelidade certos flashes do problema incrustados na alma do povo, o carioca em especial”. David Neves 
chama a atenção de uma crítica em que Paulo Emílio Salles Gomes "afirma ter Integração Racial 'retomado o falar no cinema brasileiro"' (NEVES, 1966: 261).

É curioso, entretanto, observar a oscilação de Neves, ao emitir julgamento sobre Maioria absoluta, de Leon Hirszman: "O realizador, até aqui um amante do rigor, desconhece as 'veleidades' da câmera livre, do som transportável, e se desinteressa um pouco. De certa forma uma preguiça inicial o aproxima do problema", para, mais adiante, afirmar que "o tema da preguiça que levantei" traduziria, na verdade, um espírito de inquietude e de interrogação "a respeito de um novo e comunicativo veículo de informação". Neves afirma a importância da boa técnica no cinema, porém, em decorrência da nossa condição de subdesenvolvimento "aceita essas deficiências e faz dela um ponto de partida. Nosso estado e nossa tradição, porém, são ainda de jeito a enquadrar-nos na denúncia do cineasta italiano..." (Ibidem: 259). O cineasta italiano a que Neves faz referência é Rossellini e a denúncia, provavelmente, corresponde a um debate acalorado entre o cineasta italiano, Jean Rouch (do cinema-vérite, o direto francês) e Al Maysles (do direto norte-americano). Na tentativa de impedir que o neo-realismo italiano fosse confundido com o cinema direto, Rossellini chama Rouch e Maysles de "voyeurs" que praticam um "realismo ralo e pouco dramático", com uma busca tola e incessante do acaso. Atacando com mais ênfase o cinema direto americano, Rossellini diz que "a câmera é uma caneta esferográfica, uma besteira qualquer". Segundo Fernão Ramos, "Rossellini ressente-se da banalidade fenomenológica do direto e a vê em contraposição ao realismo epífano e revelador que marca sua obra" (RAMOS, 2008: 413) ${ }^{12}$. É preciso justificar o interesse do debate em nossa discussão, pois o que o direto "fenomenológico", como cunhou Glauber, muitas vezes propôs foi o recuo da voz do cineasta em prol de um mundo que se revelaria por si, incluindo aí a manifestação do outro, sem a necessidade da mediação, política que gerou contradições, das quais trataremos mais adiante.

No diapasão das divergências entre os realismos, retomamos aqui nosso argumento de, neste capítulo, dar ênfase ao documentário, pois, se neste cinema as discussões e indagações a respeito da ética e da estética que iriam prevalecer eram

\footnotetext{
${ }^{12}$ Sobre esse debate, ver a reprodução de outros trechos em Mas afinal... o que é mesmo documentário?p.413
} 
candentes, anunciando transformações, no cinema brasileiro de ficção ainda havia o horizonte do pós-guerra e as referências do neorrealismo italiano assimiladas por uma geração anterior do Cinema Novo, com a exceção de Glauber Rocha (Ibidem: 333). E com um movimento de mão dupla, "o realismo do pós-guerra não formula uma nova proposta na tradição documentária. Articula-se em torno de ficções, que trabalham intensamente locações, temas e personagens" (Ibidem: $334)$.

Ainda assim, empenhado no entendimento do cinema direto e sua aplicação aqui no Brasil, Glauber Rocha traçou três linhas, embutindo já nos conceitos seu parecer: a primeira seria "a linha política de Marker", a segunda, "a linha cientificista e neutral, a linha Rouch" e, por último, a terceira seria "uma linha livre de observação social e política, mas sem compromisso, sem definição, que é a linha americana e sobretudo a canadense" (ROCHA, 2004: 74). No cinema do francês Chris Marker, Glauber via um interesse sobre as revoluções políticas modernas: "é muito mais o [interesse] do intelectual, do jornalista, do que propriamente o do cineasta puro. (...) A posição de CM diante desses fenômenos sempre foi uma posição política” (Ibidem: 72). Em Jean Rouch, outro francês, talvez o propagador do cinema direto francês em escala mundial, Glauber percebeu que, apesar de seu papel de revelar a África para o mundo de um ponto de vista antropológico, "em nenhum momento discutiu as contradições internas da África". Rouch seria uma espécie de "pesquisador possuído daquela neutralidade axiológica da ciência que se expõe a África, mas nunca discute, nunca coloca o problema, e que fica somente no nível da informação" (Ibidem: 73).

É curioso observar as divergências (que não são poucas), mesmo dentro do grupo de cineastas identificados ao Cinema Novo. Glauber Rocha, o líder intelectual desse cinema, emite opiniões contrárias às de David Neves. Enquanto Neves identifica um tipo de "evolução" em Integração Racial, de Saraceni, que usou substancialmente as técnicas do direto, Glauber aponta um filme que "recolhe apenas dados sociológicos e políticos, mas não elabora uma ideia completa numa forma livre" (Ibidem: 74). Em Maioria absoluta, de Hirszman, onde Neves critica um método engessado, resultado de uma certa "preguiça" de seu realizador, Glauber aponta positivamente um "determinado ponto de vista pelo político, ou seja, um filme que faz uma pesquisa e realiza uma ideia, inclusive com uma intenção de alerta político a respeito de um fato" (Ibidem: 74). 
Embora haja muitas outras questões imbricadas nas diferenças entre Hirszman e Saraceni, pelo menos no que diz respeito aos dois filmes, o que nos chama a atenção, e o que de fato foi colocado na política do direto, é a ausência do roteiro, traduzida em outros termos como a abertura para o real, ao passo que o cinema anterior estaria mais ligado a um prévio planejamento ou, como defende Bernardet, uma tese sociológica pré-concebida esperando que a realidade a legitimasse. $^{13}$

A tese de que a aplicação do cinema direto de vertente norte-americano (o "observativo") não teria sido completamente absorvida no documentário brasileiro daquele momento justifica-se ainda por um contexto social em que havia a demanda da voz do intelectual, embora já se fizesse mundialmente uma crítica à univocidade de falar pelos outros. Assim, enquanto foi possível, esse cinema caminhou numa "estética híbrida" de locução em off e captação de som direto, e numa "ética negociada" de representar o outro e emitir opiniões sobre ele. Para Fernão Ramos, essa contradição denotou a estilística do direto no Brasil "em que a possibilidade de expressar um saber analítico sobre o outro (o povo), age contraditoriamente num estilo historicamente ligado à negação da voz do saber." (RAMOS, 2008: 330). Em diretores como Leon Hirszman (Maioria absoluta), Arnaldo Jabor (A opinião pública) e Geraldo Sarno (Viramundo), por exemplo, “o direto bate e volta no degrau da alteridade, levanta a voz e consegue representar o povo do alto, enquanto conclama o espectador à práxis política" (Ibidem: 331).

A despeito das opiniões de Glauber sobre o direto euryankee, é preciso fazer distinções entre as duas propostas, a francesa e a norte-americana. De modo resumido, nos parece que a proposta dos americanos seria mais ambiciosa na busca do real. Usou-se para defini-los a metáfora da mosca na parede, que acompanha de seu ponto de vista estratégico todo o real se revelando sem a necessidade de intervenção do cineasta. Os franceses, por mais que estivessem limitados a uma intervenção menos problematizadora de questões sociais e políticas, como apontou Glauber nas propostas de Jean Rouch, estavam menos convencidos de que o real se revelaria a partir de uma utopia às avessas, com

\footnotetext{
${ }^{13}$ Lembremos, entretanto, que essa concepção de impor uma tese ao espectador não se reflete na política cinematográfica de Glauber. O discurso do cineasta baseia-se na imagem dialética, e isso, para ele, nunca significou abrir mão de um posicionamento político em prol do outro espectador.
} 
"objetividade" e sem embate, como pretendiam os americanos. Os franceses eram a mosca na sopa, mergulhando na sociedade para compreendê-la. O próprio termo cinema-vérite (cinema verdade), cunhado pelos franceses, ficou passível de críticas e foi abandonado por esse cinema direto de intervenção, que privilegiou a voz das ruas, a voz do outro. Os americanos, na eterna busca da "verdade", tomaram emprestado o "cinema verdade" para definir o seu direto. A Verdade viria, então, sem a intervenção, revelando-se por si.

No Brasil, o perfil do cinema direto francês se adequou e esteve em maior consonância com o cinema que se praticava aqui, pois possibilitou e trouxe à tona o universo verbal das ruas, o português sem as normas cultas, aquele proferido pela voz solene do locutor, e permitiu também que junto da entrevista se colocassem as devidas asserções do cineasta. Por isso, o modo híbrido. Ouvir o outro significou sair da posição de saber absoluto e deixar de lado o fechamento na tese sociológica. Descer da posição privilegiada fez com que o cineasta prestasse atenção em outros fatores, tanto relativos ao cinema quanto ao mundo a se representar. Na ficção, essa mudança de postura se fez sentir no filme Macunaíma (1967), de Joaquim Pedro de Andrade. José Mário Ortiz Ramos chama a atenção para a divergência que Heloísa Buarque de Hollanda destaca entre o Macunaíma de Mário de Andrade e o de Joaquim Pedro, ao apontar um escritor preocupado com a inexistência de um "caráter nacional" e um cineasta que justamente ironiza esse "caráter". O Macunaíma de Joaquim Pedro assumia mais o questionamento, amplificando os problemas que atormentavam o Cinema Novo, tais como "o nacionalismo que exigia redefinições; as pretensões conscientizadoras, já criticadas como paternalistas, e que clamavam por relativização; e principalmente o nó górdio da relação com o público" (ORTIZ RAMOS, 1983: 80).

Argumentos de um discurso nacionalista que fora endossado pelo próprio Joaquim Pedro e a turma do Cinema Novo (na ficção e no documentário), esses valores agora estavam afetados pela ditadura militar, pela decepção dos intelectuais com o povo, e por mudanças em escala mundial (a razão iluminista abalada desde a Guerra Mundial, o recuo do socialismo e do pensamento marxista, a ascensão das sociedades pós-coloniais e dos estudos culturais). Em suma, a visão ocidentalizante do mundo, "o macho adulto, branco, sempre no comando" estavam sendo colocados em xeque para dar abertura a uma voz que 
esteve sempre recalcada. Sem dúvida, a convergência desses fatores foi preponderante no cinema e coincidiu com o advento do cinema direto, a captação da voz das ruas, a possibilidade de emergência da voz do Outro.

\section{3.}

\section{Eduardo Coutinho: Um discurso sobre o método}

Em franca oposição com a noção moderna do saber, exposta no clássico Discurso do método, de René Descartes, no conto Um discurso sobre o método (1989), o escritor Sérgio Sant'Anna constrói um relato autoirônico de um narrador-intelectual que fala pelo outro de classe, mas que, ao longo da narrativa, sobrepõe a sua fala ao que seria hipoteticamente o discurso desse outro: "Mas o vazio no estômago falara mais alto e ele usara parte dessa grana com um cafezinho, enchendo três quartos da xícara com açúcar, o que lhe proporcionava umas tantas calorias, embora ele não pensasse assim, em termos de calorias, mas da diminuição da vontade de comer e, como requinte, que um cigarro, mesmo pela metade, era bem mais saboroso depois de um café." (SANT'ANNA, 2000: 402) ${ }^{14}$. Parece haver também uma fina ironia com o outro da classe do escritor, diante da indiferença com os problemas do outro de classe, expressa na ambiguidade da frase seguinte: "Outro, em seu lugar, talvez se magoasse com o pouco caso que a assistência dava à sua vida".

Se, no conto, Sant'Anna exacerba o discurso do método, tornando-o propositadamente excessivo e incômodo, o surgimento de um cinema que intencionou buscar o outro, sem mediações cientificistas e abstratas, objetivou libertar-se das amarras desse tipo de discurso. Embora não se possa falar nunca em ausência de ideologia, de metodologia e de perspectiva, ou de câmera objetiva e mosca na parede, como se tentou fazer crer em alguns momentos, esse cinema, que nasce para rebaixar a voz "autoritária" e excessiva do cineasta, revela-se no

\footnotetext{
${ }^{14}$ No conto, um operário que faz o serviço de faxina numa firma de engenharia vai à sacada do $18^{\circ}$ andar para fazer a limpeza dos vidros. Dá uma pausa para fumar, sentando-se à beira da marquise. O público lá embaixo interpreta sua atitude como uma tentativa de suicídio. Faz coro estimulando que o operário pule. A partir de então, o narrador-intelectual constroi uma série de raciocínios para compreender o operário, mas com um discurso radicalmente distante da realidade deste.
} 
documentário de entrevistas e tem como um de seus principais representantes o cineasta Eduardo Coutinho. Oriundo do grupo de cineastas do CPC, Coutinho dele teria se afastado, segundo o próprio cineasta em debate na Unicamp, em função do "autoritarismo" do grupo, que "mexia com a arte popular revolucionária [e que queria] mesmo mudar o mundo com aquilo ali do jeito deles" (COUTINHO, 2001: não paginado), embora afirme que a ditadura tenha sido talvez o fator que impediu a progressão do CPC em busca da voz do outro, "porque não fizeram isso".

Nem por isso as influências do CPC e do Cinema Novo foram apagadas no filme mais marcante de Eduardo Coutinho e um dos mais emblemáticos na história do documentário brasileiro. Cabra marcado para morrer (1964/1984), ainda que inscrito numa concepção de história escrita pelas bases, contada por pessoas comuns, em detrimento dos grandes personagens históricos, lança um olhar sobre atores sociais que tiveram um papel na História. Cabra marcado é forçadamente um projeto que tematiza o processo de transformação da História, dos atores e do próprio cineasta, num intervalo de vinte anos, evidenciando o fracasso no percurso histórico de um personagem assassinado e de um filme interrompido, "um projeto histórico preocupado em lançar uma ponte entre o agora e o antes, para que o antes não fique sem futuro e o agora não fique sem passado" (BERNARDET, 2003: 227). A ascensão da voz do outro, seja para reafirmar - como acontece com um personagem que dubla no filme de 1984 sua aparição no filme de 1964 - seja para refutar - o personagem Mariano negando de modo violento a ideia de um reingresso na revolução e desconstruindo um discurso que estava dado em 1964 - provoca certo constrangimento e surpresa, sensação de castração, porque o filme, deixando falar um outro bem mais complexo e contraditório do que se supunha, mostra-se também como resultado de uma secção violenta na trajetória de um intelectual pela força opressora da ditadura militar.

Configurando-se na construção de um diálogo, Cabra marcado promove o resgate da história oprimida, a história dos camponeses e a dos intelectuais, ao mesmo tempo em que assinala dentro do próprio texto a fratura entre um tipo de documentário cinemanovista e um outro situado na década de 80 que fez revisão de toda uma metodologia. Filme com roteiro escrito e detalhado em 1964; filme sem roteiro, todo trabalhado na montagem fragmentada de Eduardo Escorel, em 
1984. A opção por essa abertura, e não mais o "neorrealismo temperado com didatismo" (Ibidem: 233), como Bernardet definiu o primeiro filme, revela uma desistência de narrar pela grande História, quando seus atores sociais estão fragmentados (personagens do filme e intelectuais que nele trabalharam), e de buscar nessa História um paradigma que sirva de norte para as massas. Não mais uma situação factual com pessoas sem voz para encarnar uma tese pré-concebida, por meio da voz em off, mas personagens que expõe na tela suas subjetividades e deixam aflorar as contradições da realidade. Também o diretor do filme, o que dificilmente ocorreria num filme ligado à estilística do documentário cinemanovista, colocando-se como intelectual fraturado na tela e evidenciando para o público seu corpo e sua voz experenciadores de toda aquela trajetória histórica, corpo e voz que não poderiam estar ausentes de um filme que narra a história de um filme.

É esse modo de subjetivação do narrado, que não se dá mais pelo viés da macro-história, dos discursos totalizantes e das meta-narrativas, que leva Beatriz Sarlo a falar numa "guinada subjetiva". A proposta da guinada subjetiva é a de "reconstituir a textura da vida e a verdade abrigadas na rememoração da experiência, a revalorização da primeira pessoa como ponto de vista, a reivindicação de uma dimensão subjetiva", modo que se expande atualmente "sobre os estudos do passado e os estudos culturais" (SARLO, 2007: 18). A transferência do poder de fala acontece não de modo natural, mas, como tentamos mostrar ao longo deste capítulo, com muita relutância, porque ela reflete uma mudança na visão de mundo, como notou Beatriz Sarlo, que deixa de enxergar com solidariedade a luta do outro de classe, como se esse outro houvesse perdido uma certa inocência. Decorre daí a própria revisão que se fez na noção de "povo", principalmente no pós-golpe militar. É o próprio Coutinho que, prenunciando uma ética que vai dominar o cinema brasileiro contemporâneo, afirma ser a idealização algo mortal no documentário e exemplifica uma "postura ridícula" do cineasta em relação ao índio: "índio, você que é puro e bom me responda". A impotência do cineasta e o consequente recuo de seu caráter intelectual refletem-se na opinião de Coutinho sobre a abrangência do cinema na sociedade e seu papel de transformador: "O grave de querer mudar o mundo no documentário é que o cara vai querer mudar aquele com quem ele vai filmar. Há que se dar conta de que a 
neurose do intelectual é tão mágica quanto a religiosidade do "popular"'. (COUTINHO, 2001: não paginado)

Em artigo que mapeia as ideologias do documentário brasileiro contemporâneo, Karla Holanda fala de uma abordagem que se torna cada vez mais incisiva, não mais vinculada ao "mecanismo particular/geral", mas de temas "por um recorte mínimo, a partir da história de indivíduos ou de pequenos grupos”:

Agora, o indivíduo destacado não está mais a serviço da representação de um tipo, ele aqui é fragmentado, muitas vezes incoerente, contraditório, dramático, merecedor de compaixão, repulsa ou indiferença pelas características próprias que sua individualidade revela e não pelo tipo que representa. Ele agora é representado na sua pluralidade, ele agora é humano. (HOLANDA, 2006: 5)

A autora cita Giovanni Levi, autor cuja pesquisa está voltada para as novas modalidades de escrita da História, e para quem a micro-história centra seu trabalho numa

\begin{abstract}
descrição mais realista do comportamento do homem no mundo e que toda ação desse homem está diante de uma realidade normativa, isto é, suas ações são resultado da negociação entre as limitações impostas por "sistemas normativos prescritivos e opressivos" e sua liberdade pessoal. Essa seria a primeira das duas características, segundo Levi, que assinala a função particular da narrativa na micro-história. (Ibidem: 7)
\end{abstract}

Ainda segundo Levi, ao contrário da teoria dos "funcionalistas", em que o contexto explicava o comportamento social e enfatizava seus argumentos na coerência social, os micro-historiadores estariam concentrados "nas contradições dos sistemas normativos e por isso na fragmentação, nas contradições e na pluralidade dos pontos de vista que tornam todos os sistemas fluidos e abertos" (LEVI, 1992: 154-5 apud HOLANDA, 2006, p.8). Outra característica da função narrativa da micro-história, segundo Levi, e essa é bastante cara ao cinema de Coutinho, "refere-se à incorporação dos procedimentos da pesquisa ao corpo principal do texto, ou seja, 'o processo de pesquisa é explicitamente descrito",, rompendo com a "assertiva tradicional, a forma autoritária de discurso adotada pelos historiadores que apresentam a realidade como objetiva" (HOLANDA, 2006: 8). Ao mesmo tempo em que rompe com o discurso "autoritário" e flexibiliza a verdade do documentário, essa estética/ética reflexiva de evidenciar o processo ganha mais credibilidade e, paradoxalmente, dá credibilidade à voz do 
documentarista, esse que era acusado de detentor do discurso. Não sem motivo, esse tipo de procedimento se tornará banal no documentário contemporâneo.

Em Cabra marcado para morrer, a relativização do discurso abre uma fenda onde se revelam não tipos (a figura definitiva do camponês), mas individualidades que nos levam ao questionamento da possibilidade real de um movimento ensaiado e homogêneo da História. O que parece haver, de fato, baseado nesse novo ponto de vista da micro-história, são menos identidades cerradas e unitárias que caminhariam sempre em sentido único e de maneira sincrônica que pontos de contato entre as individualidades, "uma multiplicidade de existências com uma experiência comum nas lutas sociais dos anos 60, mas com inserções diferenciadas nessas lutas e caminhos posteriores bastante distintos" (LINS, 2004: 33). Relativização e ascensão da micro-política no documentário correspondem necessariamente a documentaristas que se esquivam de declarações ou explicações, preferindo a alusão ou a sugestão, de modo que seu ponto de vista fique subjacente, implícito no texto. Para Bill Nichols, é uma voz que não fala conosco diretamente, que acumula nela sinais, "mas sinais de quê? O argumento e a voz do filme estão incorporados em todos os meios de representação disponíveis para o cineasta, menos no comentário explícito", o que resulta não mais na voz do documentário, mas numa voz da perspectiva. (NICHOLS, 2005: 78).

Em Santa Marta: duas semanas no morro, teremos a multiplicidade de pontos de vista, problematizados, sobretudo, a partir de um discurso em crescente ascensão: o da mídia. O recuo da cultura popular e o avanço da mídia, tema abordado na ficção Bye bye, Brasil (1979), de Carlos Diegues, e no documentário O Circo (1965), de Arnaldo Jabor, é a tônica e o que dá movimento ao filme de Coutinho. Determinado a não reproduzir o discurso midiático, discurso que não excluía a favela dos noticiários, mas que a representava sempre de modo negativo, Coutinho escolhe como tema a relação dos moradores com a polícia, a relação entre eles mesmos e com a associação de moradores, as religiões, a sexualidade, o amor e a amizade, ouve os primeiros moradores do morro, colhe depoimentos sobre a pobreza, violência e preconceito, mas não emite juízo (voz de locução) sobre o material, salvo a hierarquização da edição. Deixando aflorar a voz de moradores que não têm um discurso unívoco sobre os problemas socioeconômicos da favela, o diretor relativiza o discurso da mídia, focado na violência, e relativiza 
também a perspectiva iluminista do intelectual, cujo olhar sobre a pobreza reivindica a atuação do poder público em nome da igualdade universal. Utilizando as categorias de Bill Nichols para classificar modelos de documentário, mas não reduzindo a ela os filmes, o modo reflexivo se ajusta a um tipo de filme que está preocupado com os problemas e as questões da representação. Por outro lado, Coutinho segue a vertente do direto participativo, em que interage com os entrevistados.

Involuntariamente, ou mesmo fatalmente, Santa Marta, que não reivindicou para si o rótulo de documentário com discurso social sobre a violência, é a semente de uma trajetória que vai ter continuidade em Notícias de uma guerra particular, de Kátia Lund e João Moreira Salles, via o traficante Marcinho VP; em Cidade de Deus, de Fernando Meirelles, via depoimento de Paulo Lins, e, mais posteriormente, em Tropa de Elite, de José Padilha, via Capitão Pimentel (o que dá fôlego para que retomemos os filmes de ficção, discutindo a relação próxima de realismo que esses filmes estabelecem com o documentário). Coutinho, apesar da postura de desconfiança em relação ao intelectual, adentra num tema que transborda problemas sociais e que pede uma tomada de atitude, não a dele, mas a das autoridades públicas. A frase de uma moradora causa constrangimento e nos leva a pensar novamente no papel do intelectual e seus limites, ao mesmo tempo em que mostra o abandono de uma parcela considerável da sociedade, ausente de direção e de ação: "Eu queria que vocês viessem, entrevistassem a gente e tomassem alguma solução". Se essa abertura para a realidade, possibilitada pelo cinema direto, difere do horizonte do realismo glauberiano, um realismo "que interprete e impulsione a realidade para a práxis política (...), que seja voltado para a conscientização do povo e de seu real posicionamento social" (RAMOS, 2008: 336), ela tampouco é filiada a um realismo pejorativamente chamado por Glauber de "fenomenológico", encerrado em si. Pois não é apenas "fenomenológico" dar voz a uma moradora e deixar que ela, empunhada de um microfone, indague um policial a respeito de seu "poder de interpelar o outro" e da truculência com que a polícia trata os moradores do morro, e ainda se coloque no lugar do policial ("Eu não sou contra você porque eu sei que o trabalho da polícia é difícil" e "O que eu vejo são pessoas como a gente, favelados, porque a polícia militar tem gente pobre também"), quase apontando para um policial que terá voz própria em Tropa de Elite. 
Limitando-nos aos filmes de Coutinho nos anos 70/80, em trajetória cinematográfica na qual a narrativa reflexiva implica e discute cada vez mais as questões da representação, é, no entanto, num filme de 1978, Teodorico: imperador do sertão, feito para o programa Globo Repórter, da TV Globo, que o diretor radicaliza e abre a guarda para as críticas à política de dar voz ao outro. Bill Nichols nos diz que desde a década de 1970 ocorre uma importante tendência no documentário, que muda de foco, e passa das representações do mundo histórico, com a voz dos especialistas e das autoridades, para as "representações que transmitam perspectivas mais pessoais, mais individuais" (NICHOLS, 2005: 82). Dito desse modo, percebemos que a fala desse outro que tem uma perspectiva pessoal não necessariamente é a fala do outro de classe, do outro pobre, do outro minoria, e nem sempre essa política visa deixar falar aquele que nunca teve voz política e social. No caso de Teodorico, num primeiro momento, a leitura mais evidente que podemos fazer é a aplicação torta de uma estratégia micro-política (a de dar voz ao outro) em benefício de um sujeito que sempre concentrou o poder de fala na sua figura e agora aparece na tela para revalidar e reafirmar a abrangência e a autoridade de sua voz.

Uma política que intenciona provocar o "deslocamento da construção anterior de identidades nacionais para o reconhecimento de identidades parciais ou híbridas que raramente se encaixam em uma categoria única e permanente" (Ibidem: 201) perde sua razão de ser quando encontra Teodorico, um coronel detentor de terras e de pessoas, símbolo de uma classe minoritária que concentra as riquezas do Brasil desde o período colonial, embora Consuelo Lins argumente em favor de um personagem que em determinado momento tem os sentimentos pela mulher aflorados, vertendo lágrimas diante da câmera, e que "o perturbador é justamente encontrar no latifundiário, no ditador, no monstro, aquilo que o aproxima de nós" (LINS, 2004: 23). O que se coloca em xeque não é a metodologia ou o filme de Eduardo Coutinho, mas toda uma política que surge para deixar falar o subalterno. Numa fala de Fernão Ramos, são suscitadas questões sobre a ética ou o recuo desta nesse novo documentário, em contraposição a um tipo de documentário anterior que se preocupa mais com a ética do conteúdo e menos com a ética da metodologia: 
Com outro recorte, a consciência de viés pós-estruturalista, que marca o documentário entre os anos 1970-2000, parece se importar menos com o valor do conteúdo e mais com a qualidade da posição do sujeito na enunciação desse valor. No universo da ética educativa não paira a menor sombra sobre se é ético, ou não, um sujeito enunciar seu saber. Sendo válido o conteúdo do saber, o debate ético encerra-se, sem se derramar em direção ao questionamento das condições nas quais o saber é construído ou enunciado. (RAMOS, 2008: 36)

Teodorico, único filme de Coutinho que acompanha a vida de um só personagem (integrante da elite rural brasileira, fazendeiro e político desde os anos 40, em 1978 eleito deputado estadual pelo Rio Grande do Norte), está inserido num "movimento ético" que, segundo Consuelo Lins, "permite aos personagens desenvolver suas visões de mundo no limite da capacidade de convencer, com uma intervenção pequena por parte do diretor" (LINS, 2004: 26). Esse movimento ético, às vezes excessivamente relativista, nos dará abertura para que, mais adiante, no capítulo em que trataremos mais especificamente da ficção contemporânea, possamos vincular o filme de Coutinho ao filme Tropa de Elite, cuja narrativa em primeira pessoa de um policial truculento e que não teve a intervenção da voz do diretor para apaziguar ou tolher o discurso "incontido" gerou grande mal-estar em parte da crítica especializada. Assim como no filme de José Padilha, em Teodorico, é o próprio personagem que "revela e fundamenta sua razão de ser, sem que o filme precise expressar simpatia ou antipatia, acordo ou desacordo, nem fazer avaliações conclusivas sobre o que está sendo dito". (Ibidem: 24)

\section{4 .}

\section{Entre os excessos do direto e da entrevista, o recuo da voz do diretor}

Muitos são os documentários brasileiros das décadas de 1970 e 1980 que levam consigo a continuidade do caráter político dos filmes dos anos 1960, justificados na demanda social a que o Cinema Novo e o CPC corresponderam. Como mostramos com Eduardo Coutinho (os temas políticos levantados em Santa Marta: duas semanas no morro), nem sempre a tentativa de fugir desse tipo de abordagem "didática" foi possível com a mudança da metodologia (do 
"expositivo", com locução em off, cinemanovista, marcadamente político, aos modelos "interativo" e "observativo", a partir dos anos 70), perdurando no olhar enviesado da mudança dos tempos a perspectiva política do intelectual, apesar das vicissitudes da tecnologia. Por outro lado, numa vertente mais contemporânea, o recuo da macro-política mostrou-se significativo, desaguando, por exemplo, nos filmes em que o diretor e a primeira pessoa que narra se confundem, resultando em uma abordagem que cai no particular e no subjetivo em detrimento do público, do mundo como experiência social e coletiva. Algumas críticas que confrontaremos com o direto interativo e com o direto observativo servirão a um modelo hegemônico de documentário que ainda hoje está em voga. Isto significa dizer talvez que essa crítica à vontade de verdade do direto, ainda que já estivesse sendo feita desde a década de 1980, teve pouca absorção entre os realizadores. Muito pelo contrário, o excesso de subjetividade e a falta de foco, pontos fracos apontados em certos filmes, só fizeram aumentar ao longo dessas últimas décadas.

As críticas ao direto observativo, feitas já na chegada deste ao Brasil, por exemplo, não impediram que filmes contemporâneos como Entreatos (2004), de João M. Salles, Justiça (2004) ou Juizo (2007), ambos de Maria Augusta Ramos, deixassem de existir. Filmes que apresentam uma estética filiada à metáfora da mosca na parede e que, supostamente, permitem que o outro fale sem a mediação do diretor, mediados somente por uma câmera que tem seu status sobrevalorizado por esses diretores (a ponto de Rossellini criticar o fetiche do direto pela câmera) ganham, ao mesmo tempo, confiança por conta de sua "imparcialidade", como se a câmera operasse por si só. Em Juízo, as dificuldades inerentes à produção do filme entram em choque com a política do direto, partindo de um entendimento de que a regra não permite a interferência no real. $\mathrm{O}$ que a crítica talvez não tenha apontado (não para depreciar o filme, mas para tornar complexa a linguagem cinematográfica diante da realidade suja) é que um filme declaradamente apoiado na estética do direto precisasse fazer uso de atores profissionais, já que seus atores sociais, infratores menores de idade, por lei, não poderiam ter seus rostos expostos em quaisquer tipos de mídia.

A vontade de entregar à plateia de espectadores o mundo em sua ambiguidade original, de deixar que a alteridade se manifestasse em suas contradições, muitas vezes fez com que o diretor perdesse de vista o objetivo do filme, ainda que esse objetivo se apresentasse muito menos evidente que no 
documentário "expositivo". Essa ausência de objetivos dados durante a produção deu liberdade para que o ser atuante do filme, famoso ou anônimo, se perdesse em suas manifestações, levando também o diretor a perder suas intenções, políticas ou não, de querer mudar o mundo ou não, mas que, de todo modo, não deixaram de existir, estavam lá:

\begin{abstract}
ao mesmo tempo em que criava o mito da objetividade e a não-intervenção da equipe documentarista na prática documentária, o cinema direto teve o efeito paradoxal de estimular a atuação nos documentários. Na sua versão mais rigorosa, o cinema direto não permitia interrogar ou dar indicações aos sujeitos do documentário, o que os incitava a tomar iniciativas. A escolha de protagonistas para os documentários começou a ficar parecida com um casting, em que o que se procurava eram personalidades extrovertidas que se comportavam espontaneamente diante de uma câmera e atuavam por um motus próprio, sem necessidade de serem dirigidas. No mínimo, precisavam fazer de conta que a câmera não estava ali. (TELLA, 2005: 75)
\end{abstract}

Não é demais dizer que o problema não é a encenação, já que é de costume admitir que todo documentário tem seus atores encenando diante da câmera, assim como encenam seus papéis no mundo. O problema está na contradição do método que propõe uma câmera invisível e que abole a encenação e, no entanto, tem diante de si encenações para a câmera. Outra contradição apontada por Andrés Di Tella diz respeito ao fato de que o excesso de restrições no uso de ferramentas (mediações) para que se alcance o "real puro" faz com que muitos desses filmes se pareçam com ficções, "apesar da declaração de fé documentária de seus criadores". Pois, eliminando a intervenção do entrevistador e reduzindo ou mesmo eliminando a voz em off, o filme se vê obrigado a narrar com sequências de imagens, "na mesma linguagem dos filmes de ficção, armando na montagem situações dramáticas de ações e reações, à base de planos e contraplanos que nem sempre correspondiam estritamente à mesma situação real” (Ibidem: 75).

Tocando no mesmo problema, Bill Nichols evidencia a questão ética por detrás desse procedimento ao chamar a atenção para a estrutura dramática do direto, bastante semelhante aos procedimentos da ficção, e afirmar que "quando a voz do texto desaparece por trás dos personagens que falam ao espectador, estamos diante de uma estratégia de não menos importância ideológica que a dos filmes de ficção equivalentes" (Nichols, 2005b, p.58). Ainda assim, feitas todas essas críticas que levaram o cinema direto a se assumir, a contragosto, como discurso, é um estilo que recuou na sua proposta ética, provocando uma virada de 
argumentos (da verdade a ser alcançada para os procedimentos estilísticos), mas que nem por isso o fez desaparecer na produção atual, como há pouco dissemos, e como prova Fernão Ramos:

Existe uma espécie de vergonha em assumir a representação observacional, que passa a ser edulcorada por um discurso deslocado, reafirmando o trabalho construtivo da montagem ou da modulação da imagem (angulação, luz, etc.). Se o recuo do sujeito-da-câmera não consegue mais acionar uma ética sustentável, como ocorreu no surgimento do cinema direto, a produção que corresponde a esse estilo está mais presente do que nunca. (RAMOS, 2008: 99)

Se, na tentativa de refletir a realidade, esse cinema direto mais observativo pecou pela ausência do "sujeito-da-câmera", do intelectual, abrindo excessivamente o espaço para as manifestações de alteridade e provocando os resultados que discutimos acima, temos, na outra ponta do advento do som direto no cinema, também correspondendo ao sinal dos tempos e colocando-se ao lado da crítica à univocidade do discurso, o cinema de entrevistas em que prevaleceu a intervenção do diretor em diálogo com o outro. Nesse cinema, representado em primeira instância pelos documentários etnográficos de Jean Rouch, as críticas são mais voltadas para a falta de direção nas entrevistas, ao passo que no direto observativo o foco de crítica estava na abertura irrestrita e, num sentido mais amplo, referindo-se tanto às tomadas subjetivas quanto às falas desencontradas dos personagens.

É possível que o tema da entrevista (os que a defendem sem nenhuma restrição e os que veem com certa desconfiança o modo como ela tem sido utilizada) seja tão polêmico que leve autores importantes dentro da discussão das teorias do documentário, como Bill Nichols, a apresentarem propostas divergentes quanto o seu uso no documentário. Num texto da década de 1980, publicado no Brasil em 2005, Nichols vê com bastante desconfiança o descentramento da autoria no filme (proposta de Eduardo Coutinho em filmes como Santa Marta: duas semanas no morro ou Babilônia 2000, no qual várias equipes de filmagem foram designadas para entrevistar personagens em diferentes lugares) e argumenta em favor de um benéfico "senso de hierarquia de vozes": "o filme diz: 'Entrevistados nunca mentem'. Os entrevistados dizem: 'O que estou dizendo é verdade'. E nós perguntamos: 'Será que o entrevistado está dizendo a verdade?'” (NICHOLS, 2005b: 58). Para o autor do texto dos anos 80, muitos cineastas, sem 
se precaverem com um certo distanciamento, decidem entrevistar personagens com os quais concordam e caem na armadilha da falta de ceticismo e de autoconsciência de "produtor de significado ou história", gerando "um senso mais uniforme e menos dialético de história e um senso mais simples e mais idealizado do personagem”. Contraditoriamente, para alguns representados, a aparente condição de pessoas comuns não os livra de emergir como astros, quando falta o bom senso do diretor (Ibidem: 61-2).

O mesmo Nichols, no bastante conhecido Introdução ao documentário, evoca Michel Foucault para tratar da entrevista como mais uma das "formas regulamentadas de troca, com uma distribuição desigual de poder entre cliente e profissional da instituição, com raízes na tradição religiosa da confissão". Nichols tece uma série de comparações da entrevista no documentário com outros modos de inquirir o outro:

\begin{abstract}
As entrevistas são uma forma distinta de encontro social. Elas diferem da conversa corriqueira e do processo mais coercitivo de interrogação, à custa do quadro institucional em que ocorram e dos protocolos ou diretrizes específicos que as estruturem. As entrevistas ocorrem num campo de trabalho antropológico ou sociológico; tomam o nome de "anamnese" na medicina e no serviço social; na psicanálise, tomam a forma de sessão terapêutica; em direito, a entrevista torna-se o processo prévio de "colher meios de prova" e, durante julgamentos, o testemunho; na televisão, forma a espinha dorsal dos programas de entrevista; no jornalismo, assume tanto a forma de entrevista como de coletiva para a imprensa; e na educação, aparece como diálogo socrático. (NICHOLS, 2005: 160)
\end{abstract}

O movimento pendular da opinião de Nichols talvez seja sintomático quando, num primeiro momento, reivindica a voz do diretor e, neste segundo momento, a toma como forma de poder para advogar sempre em nome de um documentário reflexivo que torne claro o processo de encontro com o outro, e que não se contente apenas com o encontro (a entrevista). Sintomático, portanto, porque sua crítica tem correspondência com um modelo de documentário bastante em voga na produção contemporânea, o reflexivo. Em sentido inverso, JeanClaude Bernardet, em seu Cineastas e imagens do povo (1985), fez uma crítica aguda à "voz de deus" nos documentários brasileiros das décadas de 60 e 70, fazendo o elogio da entrevista e da ascensão do direto para que a voz do outro emergisse. No apêndice da reedição (2003) do mesmo livro, Bernardet faz um balanço do uso da entrevista ao longo das décadas posteriores à primeira edição do livro, ressaltando o uso político da entrevista para o encontro do outro, "nos 
primórdios do direto" e seu automatismo no cinema atual. Do momento criador e da novidade de um novo cinema falado, quando o direto surgiu, no cinema atual, a entrevista "tornou-se o feijão com arroz do documentário cinematográfico e televisivo. Perderam-se as justificativas iniciais, quaisquer fossem elas descoberta da fala, dar voz a quem não tem, objetividade do documentarista etc. -, e a entrevista virou cacoete" (BERNARDET, 2003: 285).

Obedecendo a uma tendência em que o eu do documentarista torna-se tão importante quanto o outro representado, ainda que esse outro seja o assunto, Bernardet nos fala de um centro imantado ao lado da câmera, lugar onde supomos que esteja o diretor enquanto o olho do entrevistado é direcionado para esse centro, - "a câmera filma um olhar que se dirige para sua fronteira, porque aí se encontra o ponto de interesse do entrevistado, isto é, a pessoa a quem ele se dirige. Não é apenas o olhar que se dirige para esse ponto, mas também a fala" (Ibidem: 286) - , convergindo olhar e fala para o próprio cineasta. Tudo isso é reforçado por um tipo de documentário que aboliu ou rareou as outras formas de se contar uma história, concentrando-se na entrevista, priorizando a informação verbal do entrevistado em resposta ao estímulo de pergunta e perdendo a capacidade de observar o mundo com outras ferramentas.

Bill Nichols, olhando para a produção do norte do hemisfério, analisa as narrativas das minorias e as define numa categoria denominada eles falam deles para nós. Aqui no Brasil, são raros os filmes em que negros falam de negros, gays falam de gays, mulheres falam de mulheres, seguindo o modo coerente com as propostas do cinema da alteridade. Entre nós, se essas minorias foram representadas, nem sempre ou quase nunca foi uma representação criada por elas próprias, pois os problemas de representação são políticos, mas estão igualmente afetados por questões econômicas, transferência dos meios e não só do microfone para deixar falar. A mobilidade proporcionada pela leveza das novas câmeras faz com que estas passem pelas mãos dos cineastas de classe média, mas não permite que as mesmas cheguem às minorias. Em outras palavras, é esse o diagnóstico de Fernão Ramos:

Em uma sociedade cindida, como a brasileira, o outro de classe, chamado povo, pode ser definido, na raiz, como aquele que não filma. Pode ser definido como a camada social que não possui acesso a recursos ou esquemas de financiamento 
público para filmar. Apesar de muito retratado, o outro povo não filma no novo cinema brasileiro, nem filmará depois. (RAMOS, 2008: 373)

Todos os esforços para que se acabasse com o "modelo sociológico", o saber unívoco e centralizado, e deixasse o outro falar "derrubaram o pedestal do documentarista", como afirma Bernardet, contudo, não permitiram que o outro se expressasse integralmente, pois "a possibilidade de o outro de classe expressar-se está em relação direta com a propriedade dos meios de produção". (BERNARDET, 2003: 217). E, de certo modo, essa crítica talvez seja cabível ao documentário de perfil reflexivo, cujo esmero em tentar explicar suas metodologias para abordar o outro (ora revelando bastidores, ora a presença do diretor) criou, em alguns momentos, um método do discurso dentro do próprio filme, relegando, porém, a tomada dos meios pelo oprimido dos anos 60 , ou pelo excluído da contemporaneidade. Sinal de que nada mudou e que é preciso relativizar ao falar de um cinema que deu e que dá voz. 


\section{4}

\section{Do livro ao filme, os desdobramentos dos narradores}

\section{1.}

\section{Respostas da ficção às demandas sobre a voz e a reflexividade}

A tônica do capítulo anterior foi a de discutir uma conjunção de fatores que levaram cineastas brasileiros a abdicar da pretensão de falar pelo outro, procurando abrir espaço para que este falasse por si. Destacou-se que tal mudança sinalizava outra postura política decorrente de uma nova maneira de ver o mundo e de pensar o papel do artista na sociedade. Foi assinalada também a importância dos aportes tecnológicos surgidos naquele período: sobretudo em função do surgimento do cinema direto, a pretensão de eliminar a voz sociológica foi ainda mais ambiciosa. Procuramos mostrar, contudo, o quanto esse projeto era limitado, primeiro por uma questão intrínseca àquele mesmo recurso a que se atribuía a solução para os problemas relativos à revelação da Verdade, e, em segundo, pelas limitações econômicas e sócio-políticas na transferência de meios que possibilitassem que o outro produzisse ele próprio a manifestação de seus pares, tal como ocorreu com os filmes de minorias no hemisfério norte, como ilustrou Bill Nichols.

No âmbito político, e vai aí o cinema como prática social refletindo as questões do seu tempo, houve uma mudança metodológica no olhar que se lançava ao mundo. Era o momento em que se falava no fim das metanarrativas (Lyotard, 1979) - decretando-se a falência dos projetos coletivos da modernidade e a impossibilidade de emancipação da humanidade, a atingir em cheio o pensamento iluminista. No embalo de tempos "pós-utópicos", Francis Fukuyama lia Hegel em chave irônica para decretar o fim da História, a despeito do processo descontinuado da modernidade hegeliana. Era, então, natural que se fizesse notar uma mudança no modo de agir diante do Outro de classe. No capítulo anterior já evidenciávamos uma tendência generalizada de julgar arrogante qualquer tentativa de encontro com o outro, com as devidas e festejadas exceções, como o documentário de Eduardo Coutinho. 
Se o pessimismo chegou a admitir a total impossibilidade de partilha dos meios, e, por conseguinte, a decretar de uma vez por todas a falência de um projeto coletivo que visasse à igualdade entre homens e mulheres de diferentes classes, esse mesmo pessimismo crítico no julgamento dos filmes mostrou-se no limite da esquizofrenia. Isto porque, não houve, concomitantemente com a destituição do cineasta-intelectual porta-voz das minorias, um movimento para criar condições que permitissem às chamadas minorias a prática da autorrepresentação. A despeito da crítica aos porta-vozes oriundos da classe média, nenhuma luta pela democratização dos meios de produção de bens culturais se desencadeou, tanto por parte dos grupos minoritários quanto por parte dos críticos da visada totalizante, da voz sociológica. Admitiu-se, sim, o recuo utópico.

No cinema documentário contemporâneo, esse recuo transpôs a barreira do que seria uma autocrítica na representação do outro, seguido de uma proposta diferente na abordagem desse outro. Mais do que isso, alguns documentários inauguraram uma tendência não exatamente inovadora na linguagem, mas peculiar nos propósitos envolvidos: a de esquecer o outro de classe, admitindo-se a incapacidade de representá-lo ou de promover a autorrepresentação. Esse tipo de documentário, no qual o cineasta não responde mais pelo mundo, mas somente pela sua subjetividade, corresponde ao que Fernão Ramos chama de ética modesta. E, por aí, talvez, fique mais clara a razão porque enfocamos os documentários antes de chegarmos ao nosso principal objeto de estudo, constituído de seis ficções do cinema contemporâneo: se temos a informação de como esse tipo de representação do $E u$ vai se disseminar na produção documental, varrendo as outras modalidades de representação, entendemos melhor como a coerência de ideias entre diretor e personagem, paradoxalmente, vai ser cobrada no estatuto da ficção.

Como ressalta Fernão Ramos, esse tipo de documentário, em que o cineasta estabelece asserções sobre a própria vida, caminha na mesma linha do filme de depoimentos, "mesmo quando as falas são articuladas pela presença do diretor" (RAMOS, 2008: 24), como é o caso de Eduardo Coutinho. Os enunciados assertivos, antes proferidos pela voz do saber, agora são assumidos "por entrevistas, depoimentos de especialistas, diálogos, filmes de arquivo (flexionados para enunciar as asserções de que a narrativa necessita)", resultando em vozes que 
falam do mundo ou de si. E como também mostramos anteriormente, quando se faz necessário para o diretor falar sobre o outro, essa fala está carregada de reflexividade, buscando sempre evidenciar o processo fílmico e a opacidade do discurso, a parcialidade do diretor em diálogo com as parcialidades do outro. Ramos chama atenção para o caráter provisório da abordagem documental vigente na história do documentário:

A antropologia visual do final do século XX possui sua própria visão da ética do documentário, centrada na desconstrução da subjetividade da voz que enuncia. (...) Não há porque deixar de supor que a visão ética dominante na antropologia visual contemporânea terá um dia sua validade histórica ultrapassada, na mesma medida em que a ética de Flaherty representa hoje para muitos uma visão de mundo deslocada. (RAMOS, 2008: 33)

Podemos depreender daí que as sucessivas ondas de modalidades no modo de abordar o real ${ }^{15}$ estão subjugadas a um processo político-cultural de legitimação que corrobora um determinado grupo de cineastas produtores de um determinado tipo de filmes. Consuelo Lins, professora, produtora e crítica que se destaca, sobretudo, pelo trabalho teórico em relação ao cinema de Eduardo Coutinho e que, por conseguinte, legitima o mesmo nos departamentos de comunicação e audiovisual, admite a existência de uma orientação política e estética nos editais dos órgãos financiadores de filmes e nos Programas do Ministério da Cultura, que "apontam outros papéis para o documentário hoje: lugar de produção de imagens 'menores', da realização de auto-representações, da afirmação da diversidade de experiências, identidades e linguagens". (LINS; MESQUITA, 2008: 13)

Outra reflexão extra-fílmica que poderíamos empreender diz respeito à tecnologia produzida em determinado período e como ela está imbricada ao que se produz no audiovisual. Tal como ocorreu nos anos 60, quando, a partir de acontecimentos na História e das novas abordagens antropológicas, a demanda do cinema pela voz do outro se viu em vias de realização com o surgimento do cinema direto e a possibilidade de ouvir o outro pela tecnologia de câmeras que poderiam captar simultaneamente imagem e voz, atualmente, a proliferação das

\footnotetext{
${ }^{15}$ A esse respeito, ver os tipos de documentário que Bill Nichols enquadra e a que anseios eles respondiam em suas respectivas épocas. NICHOLS, Bill. Introdução ao documentário. Campinas, SP: Papirus, 2005.
} 
câmeras digitais, além de baratear o custo das produções cinematográficas, é propiciadora de uma tendência que nos interessa neste momento: a dos filmes de si próprio, em primeira pessoa.

Em palestra, posteriormente recolhida para publicação no livro Cinema do real, o documentarista Laurent Roth exemplifica a importância da tecnologia digital para esse tipo de tomada de si próprio, a partir da imagem de um outdoor que viu nas ruas de Paris. Na propaganda de uma câmera digital, a foto de um jovem com o torso nu e uma fivela onde aparece o único índice do produto anunciado: Sony. Não vemos a câmera. O que Roth quer evidenciar é o modo como a propaganda colocava em questão o olho como centro organizador do mundo e sugeria uma entronização da câmera no corpo, "um corpo produtor de imagens, mas que não passa mais pelo órgão do olhar" (ROTH, 2005: 30), olhar que, no contexto atual, "não se situa mais no nível da razão ou da cabeça, tal como Platão o pensou, mas sim no nível dos órgãos sexuais e daquilo que o homem tem de mais caótico" (Ibidem, p.34). Do olhar iluminista, o mundo estável e contemplado estaria em mutação, ainda segundo Roth, para um mundo cultural imerso e sensível, onde o olho não estaria mais necessariamente ligado à câmera. Sobre o outdoor, afirma Roth:

\begin{abstract}
Não havia mais nenhuma indicação ou detalhe a respeito da máquina, do instrumento, nem mesmo, talvez, do olhar. O que esse homem olhava? Não sabemos. Será que ele olhava o mundo? É pouco provável. Olhava para si próprio? Provavelmente, essa é a hipótese mais correta. Tal imagem me parece uma característica evidente de que a mutação técnica do vídeo implica também uma mutação da representação do homem e de sua relação com o mundo e com os outros. (ROTH, 2005: 28)
\end{abstract}

Nesse sentido, passaremos a uma análise diegética no âmbito das ficções $A$ Hora da estrela, Abril despedaçado, Cidade de Deus, Tropa de elite, Carandiru e $5 X$ favela-agora por nós mesmos para compreender as respostas que os cineastas dão a demandas como a autorreflexividade e a mudança da voz. De antemão, cabe problematizar o peso do grande narrador, incorporado pelo dono do discurso (seja o diretor, o roteirista ou o produtor) na narrativa cinematográfica, e como esse grande imagista imprime a si e ao outro na tela. A metáfora da câmera-corpo, exemplifica por Roth na citação acima, serve para pensarmos na passagem da narração em terceira para a primeira pessoa, no ato do cineasta de delegar a um 
personagem o fechamento do discurso. Por esse motivo, nosso objetivo enfoca o narrador dentro do filme: ele representa o cineasta ou ele é o outro? Na diegese, ele tem autonomia ou funciona como uma muleta narrativa para esconder um outro discurso? De que maneira o encenador se coloca na tela: refletido ou recuado? Que temáticas definem a opção por recuar ou avançar sobre o texto fílmico? Vale lembrar que algumas adaptações da ficção contemporânea mantiveram a autorreflexividade de seus narradores intelectuais. É o caso de Budapeste (2009), de Walter Carvalho, baseado no romance homônimo de Chico Buarque, e Crime delicado (2005), de Beto Brant, adaptação de Um crime delicado, de Sérgio Sant'Anna. Abril despedaçado e A hora da estrela trilham outros caminhos. Já Cidade de Deus pinça do romance um narrador. São estas algumas das questões que serão levantadas a seguir.

\section{2.}

\section{Realismo, anti-ilusionismo e metalinguagem em $A$ Hora da estrela}

Em tempos pós-utópicos de um Brasil recém-saído da ditadura militar, a cinematografia nacional da década de 1980 não experimentou a unidade de nenhum movimento estético e político, como ocorreu com o Cinema Novo nos dois decênios anteriores. A despeito da crítica feita ao intelectual na produção cultural, a diretora Suzana Amaral arriscou-se, reeditando-se no papel de artista como tradutora de demandas sociais, ao filmar a história de Macabéa, personagem alagoana do livro homônimo de Clarice Lispector. Mas o que também consideramos um passo ousado da cineasta foi a opção por deixar de fora do filme o narrador intradiegético Rodrigo S.M. A última obra de Lispector foi a sua primeira a retratar um personagem de classe social diferente da sua. Simulando talvez a insegurança com a nova abordagem, a escritora delegou ao narrador a crise de consciência diante da tarefa e do poder de contar a história de Macabéa.

Ao se mascarar, para dar voz a S.M., Clarice deixou de usar como pretexto para criar uma intimidade com sua personagem o fato de ter passado a infância entre Maceió e Recife ou de, coincidentemente, utilizar em seu ofício de autora de literatura uma máquina de escrever, mesma ferramenta de trabalho da datilógrafa 
Macabéa. Em entrevistas, a escritora chegou a contar que a dicção do outro ela tentou apreender com visitas à Feira dos Nordestinos, em São Cristóvão, no Rio de Janeiro. O narrador da novela também guarda semelhanças parecidas tanto com a autora quanto com Macabéa. Nesse sentido, Rodrigo aproveita para interpelar o leitor, como se este duvidasse do que será narrado diante de tantas diferenças sociais entre ele e a personagem:

Como é que sei tudo o que vai se seguir e que ainda o desconheço, já que nunca o vivi? É que numa rua do Rio de Janeiro peguei no ar de relance o sentimento de perdição no rosto de uma moça nordestina. Sem falar que eu em menino me criei no Nordeste (LISPECTOR, 1977:12).

Enquanto adia o início da história, S.M. também apresenta ao leitor seus sacrifícios para se aproximar da vida que será narrada. É preciso, segundo ele, se alimentar frugalmente de frutas e beber vinho branco, "pois faz calor neste cubículo onde me tranquei e de onde tenho a veleidade de querer ver o mundo", é preciso se abster de sexo e futebol, não fazer a barba durante dias, adquirir olheiras escuras, "vestir-me com roupa velha rasgada. Tudo isso para me pôr no nível da nordestina" (Ibidem: 20). O narrador crê, ainda, que este rito de passagem o transformará em outra pessoa: "Voltarei algum dia à minha vida anterior? Duvido muito". Além das muitas inferências que S.M. faz até quase a metade do livro, antes que comece a narrar a história de Macabéa, ele deduz que sua desimportância como narrador é equivalente à de sua personagem como ser humano. Em caso de ser substituído por outro narrador, S.M. impõe, no entanto, uma condição: só um escritor do sexo masculino pode contar a história da nordestina, "porque escritora mulher pode lacrimejar piegas".

Assim, a opção estética de Suzana Amaral, de eliminar S.M. da trama, ao tomar A Hora da estrela, de Lispector, como texto-base para seu filme, pode ser vista como um ato de subversão do travestismo literário de Clarice para Rodrigo em nome de um distanciamento masculino que supostamente estaria comprometido caso a narradora fosse uma mulher. Com a mudança, Amaral atenta para a complexa diegese cinematográfica, em que várias instâncias (luz, voz, música, interpretação dos atores) narram, em oposição à literatura, cujo único código é o da escrita. Mas, acima de tudo, reivindica a condição de grande narradora, solapando as vontades e a autonomia de Rodrigo S.M. Questionada 
sobre os motivos para a exclusão do narrador intradiegético e autorreferente, a diretora sintetizou a questão pelos problemas da metalinguagem no cinema, sem deixar, contudo, de evocar a clássica sentença de Flaubert quando de sua inquisição nos tribunais, acusado de ofensa à moral e à religião, sobre quem seria Madame Bovary (“Emma Bovary c’est moi”, respondeu o escritor).

A metalinguagem não funciona. É apenas uma questão de linguagem fílmica. Os filmes que falam sobre filmes, histórias embrulhadas dentro de histórias, todas essas construções mise-en-abyme. Achei que tudo isso era muito complicado para o nosso público. As pessoas não entenderiam. Portanto, decidi contar a história diretamente, 'direto ao ponto', como se diz em inglês. Em outras palavras, eu eliminei o narrador porque, no meu entender, eu era o narrador. (ROSSBERG apud STAM, 2008: 323)

Ao suprimir o modernismo do texto original em favor da apresentação da história em si, Amaral recusa a reflexividade para colocar Macabéa em destaque, indo "direto ao ponto". Em consequência disso, as opiniões de S.M. sobre a personagem que ele retrata são distribuídas nos diálogos da nordestina com outros personagens. Porém, segundo Robert Stam, a ausência de Rodrigo traz consequências, como, por exemplo, deixar o espectador menos consciente do universo burguês do narrador e mais imerso na história da trabalhadora de classe inferior. O teórico infere que a escolha de Amaral pode ser vista como menos "elitista", uma vez que provoca em nós maior identificação com Macabéa, que está sem mediação intradiegética. Por outro lado, essa falta de contemplação dos dois polos pelo espectador "suprime a realidade da classe na medida em que nos tornamos menos conscientes das diferenças sociais entre o narrador e a personagem", deslocando essas desigualdades para outro registro - entre os próprios personagens - "onde o leque social é muito mais fechado" (STAM, 2008: 326).

Assim sendo, num outro sentido o filme poderia ser visto como mais elitista, já que as reconhecidas diferenças sociais entre o personagem e o narrador são veiculadas de maneira pseudo-objetiva. A narração 'impessoal' do filme exibe a diferença social de Macabéa ao revelar que ela não consegue atender às normas burguesas de comportamento socialmente correto, normas que não precisam ser formuladas porque elas foram internalizadas pelo público de classe média que julga os personagens de acordo com elas. (Ibidem) 
Algumas das reflexões de S.M. no romance de Lispector vêm corroborar a tese de Stam. Uma delas consiste na imaginação do narrador sobre o potencial de recepção da história que está prestes a contar. Sem a perspectiva de que sua literatura tenha alguma missão revolucionária, Rodrigo se coloca no papel de "válvula de escape e da vida massacrante da média burguesia": "se o leitor possui alguma riqueza e vida bem acomodada, sairá de si para ver como é às vezes o outro". O narrador também tem consciência da nulidade da penetração de sua história na classe sobre a qual escreve. "Se é pobre, não estará me lendo porque ler-me é supérfluo para quem tem uma leve fome permanente" (LISPECTOR, 1977: 30). Narradora substituta de Rodrigo S.M., Suzana Amaral, ao menos de maneira explícita no nível da trama, não reflete, por exemplo, sobre a condição do intelectual, como faz o narrador de Lispector: "Sou um homem que tem mais dinheiro do que os que passam fome (...) não tenho classe social, marginalizado que sou. A classe alta me tem como um monstro esquisito, a [classe] média com desconfiança de que eu possa desequilibrá-la, a classe baixa nunca vem a mim" (Ibidem: 19). Sobre a estética que será usada, S.M. também reflete, como se perguntasse antecipadamente ao seu interlocutor se há bom senso em suas escolhas (ao passo que, eliminando esse longo preâmbulo de making of, o filme de Amaral tem uma estética já dada e não questionada, se olharmos para a transposição da novela de uma perspectiva modernista):

Será que eu enriqueceria este relato se usasse alguns difíceis termos técnicos? Mas aí que está: esta história não tem nenhuma técnica (...) Eu que também não mancharia por nada deste mundo com palavras brilhantes e falsas uma vida parca como a da datilógrafa (Ibidem: 36 ).

Como contraponto às desvantagens - estas que apontamos acima assumidas por Amaral ao retirar do texto fílmico a autorreflexividade, a narradora se dá ao luxo de proporcionar a Macabéa o que Rodrigo diz ser impossível, longe de seu alcance, "dar-lhe um bom banho, um prato de sopa quente, um beijo na testa enquanto a cobria com um cobertor. E fazer que quando ela acordasse encontrasse simplesmente o grande luxo de viver". Assim, diferentemente do desfecho programado para Macabéa na novela de Clarice (a morte), a cena final do filme é um corte de passagem do atropelamento para o encontro apoteótico entre a personagem e o homem loiro anunciado pela cartomante. Esse gesto 
recupera, se não intradiegeticamente, o poder de Amaral ao menos como a grande narradora da história. O congelamento da imagem de uma Macabéa que ganhou "um bom banho" e encontrou "o grande luxo de viver" como plano último do filme é a recusa da cineasta em aceitar as fatalidades do destino. A opção de Suzana Amaral reafirma, na estética realista, seu papel de intelectual, quando se recusa a também morrer. Pois, seguida à morte de Macabéa, assistimos, na novela de Lispector, à morte simbólica do narrador. "Macabéa me matou (...) Não vos assusteis, morrer é um instante, passa logo, eu sei porque acabo de morrer com a moça", constata Rodrigo S.M. (Ibidem: 86).

A vida e a morte de Macabéa como invenção literária nas mãos do narrador são retomadas no programa Cena Aberta. Exibida em quatro episódios, no ano de 2003, na TV Globo, a atração foi concebida pelo cineasta Jorge Furtado e teve a apresentadora e atriz Regina Casé travestida ora em Rodrigo S.M., ora em grande narradora, ora no papel da cartomante, ora na personagem Glória, amiga da protagonista da novela de Clarice Lispector. Interessa-nos, sobretudo, o papel de Casé no lugar de S.M. À maneira de um grande making of, que é ao que o programa se propõe, os fatos em Cena Aberta podem ser narrados, mas também podem retroceder no tempo. Roteirista da trama, Furtado explicita dualidades que ganham força e importância na linguagem do audiovisual, como as diferenças entre o contar e o mostrar, bem como as implicações contidas em cada uma dessas categorias. Assim, Regina Casé, a quem vamos nos referir como narradora, lê o trecho da obra de Lispector em que Macabéa morre, mas interpreta, como atriz que é, uma rejeição à encenação da morte. “Agora que a gente já contou que ela morre, quem sabe a gente não pode parar a história ali pelo meio, com um final mais alegre?", propõe Casé, já no início do programa. Seu poder sobre a narrativa visa extrapolar mesmo a estratégia modernista da autorreflexividade, ao confundir sua função dentro da história e a função de palavras de ordem que poderiam ser dadas tanto no nível do enredo (como personagem) quanto no nível da linguagem (como narradora). Assim, no papel da cartomante, ao vislumbrar apenas tragédias no passado e no presente de Macabéa, Casé ordena “corta!", como se pedisse novamente para que a cena fosse interrompida. A ambiguidade está no fato de que, como ocorre na obra literária, a expressão "corta" é um pedido da cartomante para que Macabéa separe as cartas do baralho a fim de que a vidente inicie a 
leitura do seu futuro. No nível narrativo, porém, a apresentadora poderia estar ordenando a retirada do que é tragédia na história.

A intenção de borrar as fronteiras entre elementos que estão no eixo da trama e outros que estão no eixo da linguagem reverbera, também, na tentativa de embaralhamento entre a ficção e a realidade. Já de início, a apresentadora explica que o programa vai escolher uma Macabéa entre as várias Macabéas do mundo real. Seguido a esse esclarecimento das regras do jogo, vemos uma fila de moças na faixa dos 19 anos de idade que aguardam para fazer o teste de elenco, o making of do making of, a narrativa em abismo da televisão, bem característica de programas como Vídeo Show, exibido na mesma emissora, ou atrações humorísticas que parodiam, no mesmo canal, as personalidades que já estão interpretando. Conforme a crítica de Robert Stam, "na era pós-modernista contemporânea, a reflexividade é a norma, não a exceção", o que leva o teórico a concluir que a reflexidade não vem equipada com uma valência política a priori, ela pode ser utilizada "pelo esteticismo da arte pela arte, pelo formalismo específico de cada meio, pela publicidade ou pelo materialismo dialético”, pode ser narcisista ou intersubjetiva, "signo de uma urgência politicamente motivada ou de uma lassidão niilista" (STAM, 2006: 176). Em vídeo gravado posteriormente sobre o processo criativo do programa ${ }^{16}$, o diretor Jorge Furtado reforça em seu depoimento a clara intenção de borrar as fronteiras entre ficção e realidade. "Assistindo ao programa hoje, eu tenho dificuldades de identificar o que é texto da Clarice Lispector e o que é texto delas (as nordestinas que foram colocadas em cena no programa). É impressionante como a Clarice conseguiu capturar a fala dessas mulheres", afirma o diretor.

Muito "fiel" na leitura literal do texto de Lispector e em algumas das propostas da escritora, Cena Aberta repete a estratégia de retardar a identificação de sua personagem. Rodrigo S.M. revela o nome de Macabéa apenas na página 43, já na segunda metade da novela. Atento à linguagem do audiovisual, Jorge Furtado adia não o nome, mas a imagem do rosto da moça que viverá Macabéa. Casé utiliza os mesmos argumentos que S.M. para justificar esse atraso. A candidata eleita só é revelada aos 30 minutos de um programa que tem menos de uma hora de duração. Para ambos os narradores, “como essa nordestina, há

\footnotetext{
${ }^{16}$ Disponível em $<$ https://www.youtube.com/watch?v=wSBCdNsYvLc $>$
} 
milhares de moças espalhadas por cortiços, vagas de camas num quarto, atrás de balcões, trabalhando até a estafa. Não notam sequer que são facilmente substituíveis". Com isso, o programa de televisão, ao adiar a escolha do rosto de Macabéa, dá um provisório protagonismo a todas as moças que estão no palco para disputarem o papel da personagem. "A gente quer contar essa história todo mundo junto, eu de Macabéa, vocês de Macabéa, todo mundo aqui já é um pouco Macabéa", diz a apresentadora, dirigindo-se às candidatas.

Novamente, a autorreferência da televisão e sua linguagem de retroalimentação são postas em destaque. Com a "deixa" de que ela também pode ser a protagonista, Regina Casé, já ciente de que seu poder de comunicação com o público popular decorre de sua "cara de pobre", pergunta, retoricamente, se as candidatas conhecem alguma artista com cara de nordestina. Como reação, o riso das moças, que Casé simula não entender. A associação entre nordestino e cara de pobre é feita pela própria apresentadora. "Eu [tenho cara de nordestina]?!?”, finge espanto e complementa, já em tom explicativo: "É que hoje em dia eu sou conhecida, mas eu continuo igual, com cara de pobre, mão de pobre, pé de pobre. Meu avô veio [para o sudeste] de pau-de-arara". Casé propõe um jogo: "desmascarar" as candidatas que não são nordestinas e que se vestiram, segundo estereótipos, como tal. No palco, ela pergunta a uma candidata nordestina se ela vestiu jeans e uma blusa estilo top para ficar com o visual mais moderno: "Você acha que lá no Ceará as pessoas usam isso?”, instaura a dúvida, remetendo as candidatas e o espectador tanto a um imaginário popular quando a um imaginário que pode ser produto das representações que a Globo faz do Nordeste em sua teledramaturgia. Regina pede que as meninas troquem o figurino e desafia a nordestina, agora "com roupa de nordestina", a dizer na frente das demais: "Eu sou carioca!". Pouco convencida, a moça repete a afirmativa. E a apresentadora retruca, em tom de brincadeira: "É naaada!", provocando gargalhada generalizada entre as candidatas a Macabéa. A reflexividade narcisista da qual fala Stam é novamente exercitada por Casé, que faz julgamentos tendo como referência celebridades da TV Globo, ainda que no intuito de desestabilizar os estereótipos. "A Xuxa não tem a menor cara de nordestina, nem a Angélica. E a Carolina Dieckmann? Não tem a menor cara de nordestina também”.

A proposta de construir a personagem a partir da vida real das candidatas segue até o fim como ponto forte. À candidata escolhida para viver Macabéa, 
Regina pergunta quais são as características das demais meninas nordestinas que ela utilizará para compor essa Macabéa coletiva. Em paralelo à ficção dentro da ficção que vai sendo construída (a história de Macabéa), Cena Aberta destaca a semelhança entre as histórias de vida das moças e a da protagonista. Em depoimentos reais, as candidatas - que já não são candidatas, mas entraram, de alguma outra forma, na tessitura da trama - contam por que motivos vieram parar no Rio de Janeiro.

Outro tema que aparece nesses depoimentos é a noção de felicidade. A consciência sobre o que significa o estado de felicidade coloca, novamente, essas personagens como sujeitos de suas próprias histórias, se lembrarmos que Macabéa sequer tinha noção sobre o que significava ser feliz. O protagonismo de Macabéa, representado pela concessão de voz às candidatas-atrizes, é recuperado, também, com a convocação de Regina Casé para que as meninas, Macabéas da história, ajudem a compor o figurino da personagem Glória. Nas palavras de Lispector, Glória se sobressaía por ser "pertencente ao ambicionado clã do sul do país". A simplória escolha do figurino da carioca pela "nortista" revela a inversão da perspectiva normatizada, que é, tanto no filme quanto no romance, a de Glória sempre olhando e criticando a aparência e as maneiras de Macabéa, uma noção perversa entre sujeito e objeto.

Para além de questões metalinguísticas levantadas aqui e que aproximam Cena Aberta da novela de Clarice Lispector, o programa guarda semelhança estrutural com o filme de Suzana Amaral. Em ambos, o narrador S.M. foi extirpado. À sua maneira, Regina Casé preenche esse lugar, materializando-se na imagem como metanarradora. Sua aparição é tão ampliada quanto a das vozes periféricas do discurso, em razão, inclusive, da ambição do programa de se abrir ao real das "milhares de Macabéas". Seu ato final como mestre de cena é impedir, mais uma vez, agora em chave metalinguística, a morte de Macabéa. Na cena derradeira, Casé substitui a Macabéa atriz pela dublê, que será atropelada por um carro. Assim, ela salva a protagonista, que ganha liberdade para sair da cena, caminhando para fora do enquadramento ao lado de Olímpico enquanto o fatídico acidente é gravado no centro do quadro.

Já a Suzana Amaral cabe o papel de grande narradora, de mostradora de imagens que orquestra um outro tipo de realismo, mais filiado à tradição do romance do século XIX que à modernidade literária da escritora. E embora nossos 
apontamentos sobre o filme de Amaral pareçam partir de um paradigma modernista - o de reconhecer na transposição para as telas a ausência do narrador autorreflexividade da novela de Lispector -, o objetivo não é o de valorar as estéticas. Por isso, feitas as considerações acerca da autocrítica no próprio tecido narrativo, o movimento de conclusão dessa análise vai em direção à reabilitação do potencial político contido na estética realista, mais próxima da versão cinematográfica de A Hora da estrela. Há que se lembrar do exemplo da chegada do cinema em cores, seguido por várias gerações de espectadores que continuaram a ver o filme em preto-e-branco como mais "realista" que o filme colorido. Curiosamente, a película colorida estava mais próxima ao que o olho humano captura fora de uma sala de cinema, no chamado "mundo real", e deveria ser, assim, mais "realista".

Movimentos estéticos do cinema que se apresentaram como alternativa ao realismo mais conservador (transparente em sua edição, de modo que a perfeita sutura da película à la Hollywood revelasse um mundo nas telas, e não uma artificialidade que deixava a linguagem opaca, justamente para mostrar que era opaca frente ao mundo real) não prescindiram do realismo. Alguns deles o tiveram como referência: é o caso do surrealismo, do neorrealismo, do realismo poético ou do realismo subjetivo. Por outro lado, há, ainda, o fato de que a teoria fílmica da década de 1970 "costumava ver a reflexividade como uma panaceia política, enquanto deixava de notar o potencial progressista do realismo" (STAM, 2008: 31). Os impasses sobre o tal potencial da estética realista são grandes e encontram na política da autorreflexividade um obstáculo para que seja considerada progressista. Mostramos, nos dois primeiros capítulos, o caráter da reflexividade no cinema, primeiro como chamamento à ação do espectador (na proposta e leitura de Eisenstein por alguns filmes do Cinema Novo) e, posteriormente, em outra chave, como mea culpa em relação à narração invisível, de terceira pessoa, com a criticada "voz de deus" (sua resposta veio, sobretudo, com o status que ganhou Eduardo Coutinho e o desdobramento de sua estética nos filmes de cineastas das novas gerações).

Em seu artigo $O$ Efeito de realidade e a política da ficção, Jacques Rancière sai em defesa da abertura ao social proporcionada pelo romance realista. O filósofo lê o clássico texto de Roland Barthes, $O$ efeito de realidade, à luz da crítica contemporânea de autores como Gustave Flaubert. Para esses críticos 
literários, o "excesso descritivo" elevou "o custo da informação narrativa", nas palavras de Barthes. Rancière vai de encontro a essa tese e avança em sua percepção acerca de autores como Dostoievski e Stendhal em nome de uma “inversão da lógica hierárquica do regime representativo". Para o autor, o efeito de realidade, o excesso descritivo - visto de modo negativo pela crítica conservadora que buscou um romance de estrutura definida, com cabeça, tronco e membros - é um efeito de igualdade. A igualdade da qual nos fala Rancière "não significa somente a equivalência entre todos os objetos e sentimentos descritos pelo romancista", também não significa "que todas as sensações são equivalentes, mas que qualquer sensação pode produzir em qualquer mulher pertencente às 'classes mais baixas' uma aceleração vertiginosa, fazendo-a experimentar as profundezas da paixão" (RANCIÈRE, 2010: 79).

Ainda que esta exposição sobre o potencial político do realismo não invalide a necessidade de autocrítica do intelectual, gesto muito bem realizado por Clarice Lispector através de seu narrador, Rodrigo S.M., e retrabalhado no seriado Cena Aberta como metalinguagem lúdica, a descrição realista de detalhes da vida de Macabéa, no filme de Suzana Amaral, deixa entrever, ainda nas palavras de Rancière, algo proporcionado pelo cinema, que vem a ser "uma forma de comunismo" que oferece "a utopia de um mundo espontaneamente comunista por construir uma percepção comum” (Ibidem: 89).

\section{3.}

\section{O ocaso da autorreflexividade na adaptação de Abril Despedaçado}

Cabe recorrer brevemente a um verídico episódio dando conta das diferenças de ponto de vista sobre o papel social do escritor. Em 1999, à época do lançamento de Desonra, do sul-africano John Maxwell Coetzee, o Congresso Nacional Africano, partido de Nelson Mandela, acusou o escritor de retratar com brutalidade a percepção dos brancos sobre os negros depois do apartheid. No romance, um professor branco é expulso da universidade onde trabalha após ser acusado de abusar de uma aluna. Ele se muda para uma fazenda e, tempos depois, sua filha é violentada por três invasores negros. Na esteira das críticas, a escritora Nadine Gordiner também lamentou a representação que fazia Coetzee. Para ela, o 
escritor reforçava, ainda, o embate entre brancos e negros. Anos depois, o sulafricano disse, durante uma entrevista, que sua conterrânea costumava citar Sartre para argumentar que um escritor deixa ao mundo um registro duradouro da verdade para que no futuro ela não seja negada. Brancos, sul-africanos e ganhadores do Prêmio Nobel de Literatura, as coincidências entre Nadine e Coetzee paravam na visão do escritor sobre o mundo.

Implícita nessa visão está uma crença não apenas no poder da grande arte de representar a verdade sem ser constrangida pelas contingências da História, mas também no artista como um privilegiado capaz de dizer verdades. Sou cético quanto aos dois ramos dessa crença. Artistas não podem mais fazer afirmações tão grandiloquentes sem provocar um sorriso. Penso que a era do escritor como um sábio legislador acabou. (COETZEE, 2013)

O constrangimento e o riso os quais Coetzee parece impingir a ele e aos demais escritores são os mesmos que atingem o escritor Bessian Vorps, no romance Abril despedaçado, de Ismail Kadaré. Homem esclarecido, habitante da capital albanesa, Tirana, e autor de ficções sobre o longínquo povoado montanhoso do norte da Albânia, Bessian vê suas crenças e seu ponto de vista sobre aquela mítica região, outrora retratada em seus livros, serem minados, ao viajar para lá em viagem de lua-de-mel com Diana, com quem se casara recentemente. Antes mesmo de chegar a seu destino, o Rrafsh - planalto extremamente acidentado cujo nome só se explica em contraste com as montanhas ainda mais escarpadas que o rodeiam - ,Bessian é alvo de ironia num jornal que comprara numa cidadezinha pouco antes de partir. No impresso, uma matéria de primeira página dedicada à viagem do casal em tom confuso não deixava claro se o jornalista, autor do texto, aprovava a viagem ou se a encarava com certo sarcasmo. Igualmente, a recepção da literatura de Bessian já enfrentara críticas por seu "descompromisso com a realidade" e isso só ficava patente para Diana à medida que ela adentrava aquele povoado: "Parecia-lhe que tudo o que falavam do Rrafsh assumia de imediato um sentido dúbio, nebuloso. BessianVorps ambientara no Norte alguns contos semitrágicos e semifilosóficos, que foram recebidos pela imprensa de forma igualmente ambígua: uns o saudaram como pérolas, outros criticaram seu descompromisso com a realidade" (KADARÉ: 63).

Custa a Bessian acreditar que suas representações dos montanheses destoam da realidade. Ao se deparar com um nativo que carrega consigo um 
guarda-chuva para se proteger, só resta ao escritor o argumento entre o que é autêntico e o que não é. Não sem ironia, Kadaré deixa entrever em sua narrativa que as convicções de Bessian estão em consonância com qualquer outro lugar, menos com o norte da Albânia:

Bessian dizia que eles não eram representantes autênticos das montanhas. Ao se afastar da região épica, por motivos diversos, eles, assim como as árvores arrancadas de sua terra, tinham se desenraizado e perdido suas esplêndidas qualidades. 'Os montanheses genuínos são os que estão em Rrafsh', dissera Bessian Vorps, apontando uma direção que indicava mais a abóbada celeste que algum ponto no horizonte. Dir-se-ia que o Rrafsh ficava no céu, e não no norte da Albânia. (Ibidem: 65)

Chama a atenção que a crença de Bessian no Rrafsh folclórico apartado dos valores da sociedade burguesa vá sendo desmantelada até mesmo pelos habitantes locais. Num jantar oferecido pelo príncipe que convidara o escritor e Diana ao Rrafsh, o soberano menciona um diploma universitário e ameaça deixar um de seus principais servos desempregado. O homem a quem o príncipe se dirige, irritado, é responsável por contabilizar a arrecadação do imposto cobrado das famílias por conta das sucessivas vinganças (vendeta) previstas no Kanun, conjunto de leis que regem o povoado. "Se você anda aborrecido com esse trabalho de feitor de sangue, não esqueça que há gente que o ambiciona, e não se trata de qualquer um, mas inclusive de gente com diploma universitário", diz o Príncipe de Orosh (Ibidem: 142).

As posições de Bessian sobre o milenar código canônico, "uma das mais monumentais constituições já elaboradas na face da terra, e nós, albaneses, devemos orgulhar de tê-la criado" (Ibidem: 71), parecem ser diametralmente opostas às de Ismail Kadaré, que já defendeu em diversas entrevistas a entrada da Albânia na União Europeia como única forma de salvar o país. Contudo, a própria história de Kadaré nos leva a questionar até que ponto o tratamento dado em chave irônica a Bessian, afastando seu ponto de vista do modo de ver o mundo do personagem, não é, na verdade, uma autocrítica. Kadaré costuma situar seus romances na tradição albanesa, assume o papel de intelectual quando é chamado a falar sobre a Albânia e, à época em que deixou seu país para viver na França, foi acusado por uns de desertor enquanto outros o trataram como um conformista (apesar da censura do período comunista, Kadaré foi um dos intelectuais mais próximos do regime). Por outro lado, em Abril despedaçado, é Kadaré, e não 
Bessian, o narrador da trama contida na primeira parte do livro, a do jovem montanhês Gjorg, impelido a matar o membro de outra família para dar prosseguimento à vendeta estabelecida pelo Kanun. Se pudermos reivindicar algum papel intelectual, na acepção primeira da palavra, ele estará sendo desempenhado por Kadaré. É do escritor, antes mesmo do surgimento de Bessian na trama, a tentativa de provar que não há beleza, mas apenas derramamento de sangue como resultado da obediência ao Kanun e às leis patriarcais:

O ódio aos Kryeqyq, que o pai havia tentado acender naquela manhã de janeiro, dava a impressão de se apagar com a luz do dia. Gjorg não chegara a perceber que se as chamas do ódio não se expandiam, era porque o próprio incendiário, $o$ pai, possuía a frieza do gelo. Ao que parecia, a ira fora esfriando no curso dos anos da longa vendeta, ou jamais existira. (Ibidem: 44)

No ápice do romance, uma calorosa discussão entre Bessian e o médico do Rrafsh, dá claros sinais de que Kadaré está no lado oposto ao do personagem escritor. Cabe, aqui, a transcrição do diálogo, situado já bem próximo do desfecho da trama:

\section{Médico:}

Os senhores possivelmente sabem que, conforme o Kanun, caso duas pessoas se confrontem e uma delas morra, enquanto a outra sai ferida, a ferida é que paga o excedente de sangue. Em suma, como eu dizia no início, por trás do cenário meio mítico se encontra com frequência a economia. Pode parecer cínico, mas nos nossos dias a vingança, como tudo o mais, converteu-se em mercadoria.

Bessian:

Ah, não. As coisas não são assim tão simples. Naturalmente, a economia tem seu papel na explicação de muitos procedimentos, mas não se deve exagerar.

(...)

O senhor leu Marx?

(...)

É uma explicação ingênua demais, para não dizer cínica...

Médico:

Ingênuo é o senhor, ingênuo e cínico ao mesmo tempo, o senhor e sua arte

(...)

Os livros do senhor, a arte do senhor, cheiram a crime. Em vez de fazer alguma coisa por estes montanheses desgraçados, o senhor assiste à morte deles, busca nessa morte temas ardentes, encontra nela a beleza para alimentar sua arte. Não vê que essa beleza mata, como, aliás, já disse um jovem escritor que o senhor certamente não aprecia. O senhor me traz à lembrança aquelas salas de teatro dos palácios dos nobres russos, em que o palco é amplo a ponto de permitir apresentações com centenas de atores, ao passo que a plateia é tão pequena que só comporta a família do príncipe. O senhor se assemelha a esses aristocratas. Leva 
um povo inteiro a representar uma tragédia sangrenta, enquanto assiste de camarote e faz pilhérias, junto com a sua dama.

Bessian:

E o senhor, falo do senhor como médico, alguém que supostamente compreende as coisas da maneira correta, por que participa desse teatro, como o senhor mesmo disse? Por que se deixa sustentar por ele?

Médico:

Acho que o senhor tem razão. Não passo de um miserável fracassado. Mas ao menos tenho consciência do que sou e não enveneno o mundo com livros (Ibidem: 181)

Ao fim, diante do reconhecimento de seus escritos em dissonância com a realidade e pelos percalços que enfrentou, Bessian reflete que talvez o Rrafsh tivesse cobrado um tributo que de fato lhe era devido, "uma taxa por seus escritos, pelas ninfas e valquírias montanhesas que os povoavam, por aquele diminuto camarote posto diante de um palco onde um povo inteiro se ensanguentava" (Ibidem: 193).

As acusações que se faz ao escritor são semelhantes às explicitadas no documentário À Margem da imagem (2003), de Evaldo Mocarzel. No filme, moradores de rua criticam a tentativa do famoso fotógrafo Sebastião Salgado, credenciado pelo jornal Folha de S. Paulo naquela ocasião, de registrar a distribuição do sopão sob um viaduto da capital paulista. "Daqui a pouco, com aquelas fotos, ele vai ganhar muito dinheiro. E a gente? Vai sempre ficar ali embaixo, vai sempre ficar ali necessitando. Se quiser tirar fotos, vai ter que vir na sopa, vai ter que conviver com a gente na sopa", relata ao cineasta um morador de rua. Em outro eixo, tal qual a autocrítica de Kadaré ao seu próprio ofício como escritor, Mocarzel também se torna ele próprio explorador da imagem do outro ao registrar em seu filme o cotidiano das ruas e trazer para o material fílmico acusações que lhe são destinadas. Além de mostrar que moradores de rua tem um discurso bem mais esclarecido do que se supõe (uns se distanciam, inclusive, para apontar o "povo", aquele mesmo concebido pelos intelectuais dos anos 60, como portador do problema da falta de conscientização política para levar o país adiante), Mocarzel contempla no texto fílmico uma fala de desconfiança em relação ao diretor (ele mesmo) como suposto portador de demandas sociais: ao se ver na tela, um dos entrevistados coloca em suspeita a atitude altruísta do cineasta fora das telas. "Se eu chegar na sua casa e tocar a campainha para pedir um prato 
de comida, tenho certeza que você não vai me receber. Só hoje, amanhã você não me recebe mais. Isso o diretor esqueceu de colocar no filme", diz um dos personagens a Mocarzel.

Embora não seja intuito deste trabalho fazer cobranças de fidelidade das adaptações cinematográficas de textos literários, julgamos pertinente a comparação entre a trama do livro de Ismail Kadaré e o Abril despedaçado de Walter Salles, no sentido de nos permitir ensaiar algumas análises e apontar para algumas possibilidades. Chama a atenção, por exemplo, que quase tudo o que está contido da página 60 (quando ocorre a entrada de Bessian na história) até o final do livro, na página 200, tenha ficado de fora do filme. De antemão, pode-se afirmar que a recorrente dificuldade do cinema brasileiro de ficção em tornar a classe média objeto de seu enredo é reiterada no filme de Salles. Mais que isso, o intelectual na diegese do filme, como personagem mediador de conflitos, sobretudo como fracassado nessa mediação, continua eclipsado e deliberadamente alijado das telas por decisão do próprio diretor-intelectual. Nesse sentido, vale relembrar o arco "evolutivo" empreendido por Glauber Rocha: primeiro, com o objetivo de redenção do oprimido logrado por Antonio das Mortes em Deus e o diabo na terra do sol, depois, com a decepção do jornalista Paulo Martins em relação ao povo e aos projetos coletivos elaborados para ele em Terra em transe. Como bem destaca Guilherme Sarmiento em contundente ensaio sobre a tendência intelectual da produção audiovisual em tempos recentes, Narradores de Javé, da diretora Eliane Caffé, aparece como o filme que "melhor expressou criticamente a situação do intelectual dentro da perspectiva dos novos tempos" (SARMIENTO, 2005: 88). Na história, o alfabetizado Antônio Biá é expulso para fora dos limites da cidade por escrever cartas em nome de outras pessoas a fim de simular uma demanda de trabalho para se manter como empregado dos correios. Mas retorna ao centro das atenções com a missão de recolher relatos dos mais velhos e apresentar as narrativas, "as histórias das origens, os guerreiros lá do começo", como patrimônio imaterial. Biá deve responder a essa demanda social para evitar que as terras do povoado sejam submersas por uma represa que está sendo construída. Para decepção geral, Biá apresenta um livro em branco.

Já no filme Abril despedaçado, a opção foi por eliminar o escritor Bessian, que vem a ser no romance de Kadaré o ponto mais crítico e de maior inflexão em relação ao que vinha sendo desenhado numa trama cujo enfoque recaía, em seus 
primeiros capítulos, sobre a vingança entre famílias e gerações regidas pelo Kanun. Em entrevista à época do lançamento do filme, Walter Salles, que assina o roteiro do longa-metragem com Sérgio Machado, Karim Ainouz e Daniela Thomas, justificou a mudança:

O escritor é um personagem literário, que se exprime essencialmente pela palavra, num mundo onde ela está praticamente ausente. Já o circo trouxe a possibilidade da introdução dos valores do nomadismo numa cultura gregária. A introdução daqueles que traziam não somente o movimento num mundo arcaico, paralisado pelo tempo, mas também a arte, o entretenimento, a paixão... O circo mambembe é, portanto, uma opção essencialmente cinematográfica. (SALLES: 2002)

À parte questões estéticas próprias da linguagem cinematográfica que impediriam a figura de um escritor na fatura de um roteiro cinematográfico, como o próprio Salles argumentou, ao atrelar Bessian à trama literária, embora haja demonstrações contrárias a esta tese (Narradores de Javé é um dos exemplos), Abril apresenta pelo menos um resultado diverso em relação ao romance. O filme tira de foco o escritor, que no livro tem sinal negativo na perspectiva do autor. Bessian, grande conhecedor do Kanun, está alheio aos sofrimentos causados pelo código à população local, seu papel de interventor é nulo, seu caráter é questionável pela crítica, pela imprensa e pelos nativos do Rrafsh. Além disso, indiretamente, o escritor é responsável pela morte do montanhês Gjorg, ao impedir qualquer aproximação de sua mulher com o personagem que conta os dias para a própria morte. No enredo de Kadaré, a empatia entre Gjorg e Diana, mesmo à distância, é um dos motores do romance. Ocorre, porém, que o encontro amoroso jamais se realizará. A adaptação de Salles recoloca na cultura e na arte o peso da redenção como alternativa ao ciclo de morte. Por tabela, o diretor relega o debate sobre o papel do intelectual dentro da história. Bessian, situado no polo negativo da narrativa, transforma-se no artista de circo Salustiano, que não chega à cidade para explorar a tragédia alheia, mas para doar alegria a um cenário tão árido. Não há impedimentos também para Tonho viver um primeiro amor às vésperas da aguardada morte. Clara, a parceira do circense, é sua afilhada, e não sua mulher, como ocorre na história de Kadaré com o casal Bessian e Diana. Outra diferença importante é que Salustiano, ao contrário de Bessian, desconhece o código de vingança, não é um intelectual defensor do Kanun e tampouco 
poderia expiar alguma culpa de Salles, como já observamos na autocrítica do autor albanês.

Na adaptação de Salles, perde-se Bessian, cujo ponto de vista é divergente e conflituoso em relação ao que o autor do livro pensa sobre o montanhês vitimizado pelo Kanun, e se ganha um ponto de vista inusitado, confluente com a perspectiva do cineasta - o do contador de histórias. Pacu, figura inexistente no livro de Kadaré, personagem que aparenta ter 10 anos de idade, irmão mais novo de Tonho. Como argumenta Ismail Xavier, Abril despedaçado dá prosseguimento a um percurso iniciado por Salles em Central do Brasil, de desenhar uma trajetória de redenção para os seus personagens, e se distancia da deriva e da violência que dominam a pauta até o fim em filmes como $A$ grande arte e Terra estrangeira. "Se $O$ primeiro dia repõe a força das engrenagens que se mobilizam para sabotar as esperanças do novo milênio, Abril despedaçado encena uma variante, mais complexa em sua trama, do percurso de salvação já visto em Central do Brasil" (XAVIER, 2007: 260). No texto Aos amigos de Abril, que Salles distribuiu à equipe durante as filmagens, ele afirma que "precisava de um olhar inocente", explica que Tonho está dividido entre a tradição e a ruptura e que Pacu é o agnus dei, o cordeiro de deus, "o cordeiro sacrificial que lava, com seu sangue, o pecado dos outros. Límpido, sem máscara, o menino é o único que consegue ver além das cercas que definem o mundo dos Breves. É o único que, de alguma forma, domina a palavra, e a usa para se projetar no território dos sonhos e da imaginação" (BUTCHER, 2002).

A tendência da narração em primeira pessoa como alternativa à totalização do discurso, que vínhamos apontando no percurso deste trabalho, aparece com a ascensão da figura de Pacu. Com o personagem, Walter Salles se eximiu de críticas que pudesse vir a sofrer por abordar uma tragédia distante da sua realidade e "perdeu" o monopólio sobre a narrativa, levando-se em conta que, ao menos em tese, é esperada a relativização de verdades absolutas no discurso em primeira pessoa. Mas, longe de confrontar pontos de vista, o drama da família nuclear dá tão exclusivamente a Pacu o poder de narração da história. A cena de abertura do filme, na verdade, já é, sem que o espectador saiba, a última caminhada de Pacu sobre o solo árido. Para que a história não provoque sustos e inicie já com uma 
morte inexplicável, Salles absorve qualquer impacto e recorre ao recurso do contar para, em seguida, mostrar ${ }^{17}$.

A fala introdutória de Pacu é longa e toma os seis primeiros minutos do filme numa sequência de cenas em que ele apresenta a família. Seu testemunho é costurado com imagens que reiteram o seu discurso:

"Meu nome é Pacu, é um nome novo, tão novo que ainda nem peguei costume. Tô aqui tentando alembrar uma história. Às vezes eu alembro, às vezes eu esqueço. Vai ver é porque eu tenho outra que não consigo arrancar da cabeça: é a minha história, de meu irmão e de uma camisa no vento"

Corte da câmera para a camisa ensanguentada, pendurada no varal, ao vento. Pela lei do sertão, a mesma do Kanun no romance de Kadaré, quando o sangue da camisa do morto passa a um tom amarelado, é hora de colocar em ação a vingança. Desta vez, um dos Breves vingará Inácio, o irmão mais velho, assassinado em emboscada por um dos Pereira. A missão de Tonho está dada pelo pai. Outro corte para a imagem de uma bolandeira, onde o pai trabalha:

"O pai é quem toca os boi pra rodar a bolandeira. No tempo de vô, os escravos faziam o serviço todo. Agora é nós mesmo"

Close dos rostos de Tonho e da mãe trabalhando na bolandeira:

“Tonho, meu irmão... É quem mói a cana. A mãe recolhe o bagaço"

Na cena seguinte, Pacu tenta pegar uma pesada rama de cana no chão do terreno. Mas deixa cair. A ação, em princípio banal, é suficiente para que o menino introduza uma visão divergente de mundo que funcionará como motor da história:

"A mãe costuma dizer que Deus não manda o fardo maior do que a gente pode carregar. Conversa fiada. Às vezes ele manda um peso tão grande que ninguém aguenta."

17 Caso exemplar da moldura no cinema, $O$ Gabinete do Doutor Caligari começa com o personagem Francis dentro de um manicômio avisando ao seu interlocutor que contará uma terrível história. "I'lltellyou". O espectador é, então, transportado à trama de fato por meio de um flashback. Ao longo de todo o filme, os crimes de Caligari e seu acompanhante Cesare são mostrados sem que haja a intervenção em off de Francis. O desfecho do filme é um retorno ao manicômio, onde Francis retoma a fala para dar sentido à história que foi contada ao público. 
Em seguida, vemos um terreno árido e excessivamente ensolarado. Em plano interior, a família trabalha na própria oficina, fazendo rapaduras. A temperatura é alta, os personagens da família estão à beira de enormes tachos que cozinham o caldo da cana. Novamente, o caráter indubitável da imagem cinematográfica está no fato de a fala de Pacu sublinhar quadro a quadro. Mais uma vez, o cotidiano de trabalho da família é utilizado para que o menino transcenda em suas interpretações:

"Nós vive em Riacho das Almas, fica no meio do nada. De certo mesmo, só precisa de ter ciência de que fica em cima do chão e debaixo do sol. E o sol daqui é tão quente, mas tão quente, que às vezes a cabeça da gente ferve que nem rapadura no tacho"

O prólogo de Pacu se encerra com a confirmação de que o personagem principal da trama é narrador onisciente, mesmo que suas motivações para agir passem pela emoção, e não por um conhecimento histórico da vingança de gerações entre os Breve e os Pereira. Diferente do romance de Kadaré, o filme não dá a ver a origem e o ponto de partida para o ciclo de mortes. A memória mais longínqua é recente e não pertence aos velhos, pertence a Pacu, que acorda de um sonho com o irmão Inácio. Nele, o menino era carregado pelo irmão quando este foi morto por um membro dos Pereira. Trata-se de um sonho que rememora um fato. Contudo, a experiência colada à morte não fará de Pacu mais um sujeito que vive para no futuro vingar e honrar o nome de sua família. No romance de Kadaré, a ausência do desejo de vingança em Gjorg, "que o pai havia tentado acender naquela manhã" e que "dava a impressão de se apagar com a luz do dia", transforma-se, no filme de Walter Salles, não em sentimento nulo, mas força contrária que tenta impelir Tonho a dar fim à sucessão de mortes. Apesar de cumprir a ordem do pai e matar o assassino de seu irmão mais velho, Tonho continuará sendo pressionado a fugir de um projeto que dividirá seu mês de abril entre a vida e a morte. No romance, essa força centrífuga que estimula a fuga de Gjorg do eterno retorno não existe. No filme de Salles, ela é exercida sobre Tonho pelo menino Pacu.

Explica-se, deste modo, o desejo inicial de Walter Salles de que o filme se chamasse Bolandeira. O equipamento de engrenagens tracionado por bois é a metáfora da força centrípeta contra a qual Pacu luta. No documentário $A$ 
Bolandeira (1968), de Vladimir Carvalho e que é uma das principais inspirações de Salles para Abril despedaçado, um cartaz define a máquina, segundo Antonil, autor do século XVIII, em Cultura e Opulência do Brasil: “... roda superior também grande, que chamão volandeira porque o seu modo de andar circularmente sôbre a moenda, se parece com o voar de hum pássaro quando dá no ar seus rodeios". O objetivo do curta-metragem é mostrar o desaparecimento da bolandeira, que vinha sendo substituída por equipamentos mais modernos. Mas um jogo de oposições narrado em off denota, mais que a simples ação mecânica na relação da máquina e dos bois, a opressiva engrenagem da história agindo sobre homens pequenos: "Bois mansos que puxavam docilmente a bolandeira ruidosa". O poema de Jomar Moraes Souto, recitado em A Bolandeira, aproxima de Abril despedaçado o sentido da engrenagem em ambos os filmes ("E os homens da bolandeira, ausentes do mel e da renda / Assimilando a suadeira do inferno que se sustenta"). Em Abril, a tentativa do pai de vender as rapaduras ao comerciante dá sinais de que seu modo de vida está parado no tempo. Ele diz ao dono da loja que há erro no pagamento da quantia. "Os preços baixaram com as usinas a vapor. É o progresso. Eu acho que é o senhor que devia seguir esse exemplo, Seu Breves. Rapadura é o que não falta”, responde o comerciante, denotando o atraso da bolandeira. Em pelo menos dois momentos, Salles dá a Pacu o poder de julgar a trajetória circular de sua família, sempre a caminho da morte, pelo movimento da bolandeira. Primeiro, ao interpelar o irmão com a constatação do automatismo dos bois, que giram no eixo durante a madrugada, mesmo que não haja trabalho para ser executado. "Tonho, os boi tão rodando sozinho!". Mais adiante, como argumento para que Tonho fuja do destino selado pelo pai, que é quem comanda o movimento do gado na bolandeira durante o dia. “A gente tá que nem os boi, roda, roda e nunca sai do lugar".

O contraponto que será apresentado por Pacu a Tonho está no litoral. O mar, "cotidiano da classe dominante como inatingível para o pobre da favela" em O primeiro dia (NAGIB: 19), surge aqui como promessa. Elemento recorrente e símbolo de ruptura no cinema brasileiro ${ }^{18}$ desde Deus e o diabo na terra do sol, o

\footnotetext{
${ }^{18}$ Lançado recentemente no circuito de exibição, o filme A História da Eternidade (2014), de Camilo Cavalcante, faz uma construção onírica do mar como possibilidade de existência alternativa à aridez humana do sertão. O artista Joãozinho (Irandhir Santos) conta histórias idílicas de seres marítimos à sua sobrinha Alfonsina e a faz crer que ela conhecerá o mar no dia de seu aniversário de 15 anos. Fisicamente, a menina não conhece o mar, mas, sentada numa
} 
mar chega ao menino por meio de um livro dado pelo casal de andarilhos artistas de circo. Pacu avisa que não sabe ler as letras, mas que lê as figuras. Mais tarde, identifica o desenho de uma sereia como sendo a moça que deu a ele o livro. A partir daí, Pacu passa a tecer uma história idealista e alternativa à realidade:

Pacu:

Um dia a sereia subiu pra riba do mar, viu e viu o juazeiro, as vaca, as montanha, os capim, e quando ela olhou pra cima da caixa de rapadura viu o galinho do pescoço pelado cantando pra ela (...) ela achou tudo lindo, mas o que ela gostou mesmo foi quando ela viu o menino" / "Tô tentando me alembrar a história, mãe. Às vezes eu alembro, às vezes eu esqueço.

Mãe:

Pois esqueça.

Por fim, o encanto da sereia Clara, a artista de circo, sobre Tonho dará a Pacu a sensação de que seu dever foi cumprido. O menino volta a lembrar das histórias que ele mesmo inventa. Numa delas, ele é transformado em peixe pela sereia, que o leva para viver debaixo do mar, porque "no mar ninguém morria e tinha lugar pra todo mundo". Quando Clara chega à janela do quarto de Tonho e diz que não está mais presa e que ele também pode (se libertar), Pacu abre mão das próprias ilusões (ou vira peixe), toma o chapéu e a fita de luto do irmão enquanto este dorme depois da noite de amor com Clara e pega o caminho em que será alvejado no lugar de Tonho.

No romance Abril Despedaçado, Kadaré anuncia a figura de Ali Binak, o velho exegeta do Kanun, um "emissário da paz" que teria, inclusive, o poder de anular uma vendeta após análise particular de um caso. Há uma expectativa, com isso, de que, até o final do romance, o destino do Gjorg possa ser desviado do caminho natural, que é a morte por um membro da família Kryeqyq. No filme, o iletrado Pacu, regente da história, cumpre uma função parecida com o que se esperaria de Ali Binak. Embora sem qualquer conhecimento profundo daquele ciclo de vinganças, Pacu é o propulsor de Tonho e de sua saída pelo mar-tangente.

pedra no alto de um morro, com o vento fresco, os olhos fechados, o rosto salpicado de gotículas de água, o som de uma concha marítima colada ao ouvido e a narrativa de Joãozinho, Alfonsina sai do sertão para o mar. O que ficará de herança do tio não é tanto a visita explícita ao mar, mas o desejo que ele despertou na menina em romper com a rigidez patriarcal e a possibilidade de que ela não renuncie aos seus sonhos. Nesse sentido, o mar assume um sentido utópico. 
É dele, também como um exegeta das imagens, o lampejo que traça para o irmão o lugar utópico "onde ninguém morria e tinha lugar pra todo mundo". Salles, ao inserir um personagem inexistente no texto original e dar a este autonomia para narrar, traduzida na narração em primeira pessoa, afasta de si o papel de intelectual portador da razão para julgar, mas inscreve o filme numa moral da história de superação. Questionado sobre motivos que o levaram a modificar o final trágico de Abril despedaçado, o diretor afirmou que tem "uma tendência a desenvolver personagens que se outorgam uma segunda chance, se rebatizam, que conseguem redefinir o seu lugar no mundo" e reafirma sua postura de cineasta que quer provocar mudanças. "O que me leva ao cinema é a possibilidade de alteração de um estado de coisas, de uma ordem previamente estabelecida" (SALLES: 2002). Entre a crítica negativa de uma ética recuada, a ética modesta da qual fala Fernão Pessoa Ramos, a possibilidade de que a primeira pessoa seja uma forma de esconder o discurso do diretor, acuado por acusações contra o intelectual, caberia também uma crítica positiva no sentido de talvez reconhecer se essa estética da primeira pessoa não estaria propondo uma nova ética no cinema. Por outro lado, essa possibilidade de nova ética não nos eximiria de perceber que Pacu responde mais aos anseios de transformação social de Walter Salles, dando margem à conclusão de que o menino não passaria, no filme, de uma falsa primeira pessoa, que encontra sua verdadeira concretude no discurso do cineasta.

\section{4.}

\section{Pelas mãos seguras de Buscapé: deslizamento de classes em Cidade de Deus}

Luiz Zanin Oricchio, no livro em que trata do cinema da retomada, comenta que Cidade de Deus (2002), de Katia Lund e Fernando Meirelles, talvez tenha sido o filme mais debatido na história do cinema brasileiro (numa época em que ainda não havia sido lançado Tropa de Elite). Dados da Agência Nacional de Cinema, a Ancine, mostram que, no Brasil, Cidade de Deus teve público superior a três milhões de espectadores. Não espanta, portanto, que tenha sido igualmente discutido. Observando alguns apontamentos, tentaremos elucidar parte da 
polêmica, no que se refere à utilização da primeira pessoa, e os problemas suscitados pelo narrador "de dentro".

Cidade de Deus, o romance de Paulo Lins, tem origem a partir da vivência de seu autor no conjunto habitacional da Cidade de Deus, favela (ou comunidade) localizada na Zona Oeste do Rio de Janeiro. Sua urgência como ficção responde à pesquisa que Lins vinha realizando com a socióloga Alba Zaluar, cujos resultados foram publicados nos livros $O$ condomínio do diabo (1983) e A máquina e a revolta (1985). Estando embasada não apenas no discurso da testemunha, mas nas pesquisas realizadas dentro do campo sociológico, a ficção de Lins tinha ainda o aval do crítico literário Roberto Schwarz, cuja manifestação de legitimação se fez no calor da publicação. Além do elogio à composição estética do romance, Schwarz chamava atenção, principalmente, para o "ponto de vista de classe - de objeto de ciência a sujeito da ação" (SCHWARZ, 1999: 170).

$\mathrm{Na}$ transposição para o cinema, o livro sofreu algumas alterações e uma das que mais nos interessa diz respeito ao crescimento desse narrador "de dentro" na trama cinematográfica. Buscapé, cuja aparição no romance estava limitada a cerca de 60 páginas, num calhamaço de mais de 550 páginas, agora aparecia no filme de Fernando Meirelles e Katia Lund como sujeito onisciente, pontuando toda a ação da narrativa ao longo das duas horas. Em outras palavras, Buscapé seria o alter ego de Paulo Lins, “o informante do antropólogo para quem traduz os códigos do mundo em que se formou" (XAVIER, 2006: 141). Dentre as muitas implicações no debate, interessa aqui pensar nos problemas suscitados pelo narrador onisciente, ao passo que temos em O Homem que Copiava (2003), de Jorge Furtado, um narrador (André) que, dado seu olhar particularizado, coloca em terreno instável a própria narrativa do filme. André, também sujeito da ação e não mais "objeto" oprimido e narrado pela classe média, nos mostra sua trajetória através do manual de ascensão, como afirmou Ismail Xavier. Não menos pragmático, porém dentro de um contexto talvez bem mais complexo, Buscapé também constrói seu manual de ascensão, embora Ismail, em seu artigo no qual investiga a corrosão social, o pragmatismo e o ressentimento no cinema brasileiro contemporâneo, reserve para Buscapé, por motivos óbvios, o manual de sobrevivência.

Assim, somos apresentados ao informante do antropólogo logo de início, nos segundos iniciais, com a imagem de Buscapé mirando não a Cidade de Deus, 
mas o espectador que o assiste. É dessa imagem - Buscapé fotógrafo - que o filme vai nos situar no presente, para só em seguida retomar a história da Cidade de Deus. É já nessa imagem - Buscapé mirando o espectador, depois de já ter narrado toda a história da Cidade de Deus - que ficará evidenciada a ascensão do personagem, pois essa lente que agora vê a classe média, para quem ele fala (lembremos que ele é o informante do antropólogo), é a lente do jornal lido pela classe média, o Jornal do Brasil dos anos 1980. Quando somos confrontados com essa lente pela segunda vez, ao final do filme, a narrativa de Buscapé já terá sofrido grande mudança, se profissionalizado.

No início do filme, com a câmera na mão, na situação dramática de linha de tiro em que se encontra, o fotógrafo Buscapé recapitula num giro de $360^{\circ}$ os anos 60: "Uma fotografia podia mudar minha vida, mas na Cidade de Deus se correr o bicho pega, se ficar, o bicho come. E sempre foi assim... desde que eu era criança”. Deste modo, Buscapé mostra sua autoridade de narrador, testemunha dos fatos desde o início, quando uma série de enchentes que acometeram a cidade fez com que moradores de diferentes localidades para lá se mudassem. Buscapé começa, então, sua explicação didática sobre os primórdios da CDD, como costumam chamar, para dar sentido à gênese do tráfico de drogas na localidade que nunca foi paraíso, mas, que agora, no presente, era vista pelo menos como um lugar diferente do inferno atual. Antes disso, porém, é preciso ressaltar sua função de mediador. Na pergunta de Dadinho, que se tornará o bandido mais violento da trama, aproveita a oportunidade para se apresentar ao seu espectador: "Como é que é teu nome, moleque?", Buscapé se desloca da trama dramatizada para a função de narrador e responde em voz off "Desculpa aí, esqueci de me apresentar", e, voltando ao diálogo como quem quisesse mostrar ao espectador sua ambivalência de narrador e personagem experiente dos fatos, apresenta-se para Dadinho: "Buscapé”.

Sob a justificativa de explicar o desenvolvimento da Cidade de Deus, o narrador dá início à construção dos personagens, a começar por Cabeleira, um dos componentes do conhecido trio Ternura: "Esse cara aí é o Cabeleira, pra eu contar a história da Cidade de Deus, eu preciso começar por ele, mas pra contar a história dele, eu preciso começar com a historia do trio Ternura". Os outros componentes do trio Ternura são Alicate e Marreco, este último irmão de Buscapé, de modo a mostrar mais um ponto de legitimação que autoriza a narração do fotógrafo- 
narrador. Contudo, sua onividência narrativa não se realiza no plano da dramaturgia. São muitos os casos narrados, mas poucas as aparições de Buscapé nas situações. Embora presentifique uma série de acontecimentos, a ideia pressuposta na narração parece ser mais a de um 'ouvi dizer que' do que propriamente um improvável ter estado em todos os lugares. Por outro lado, cabe a Buscapé esse papel de coletor dos causos quando nem sempre é possível que os outros narrem elucidando as histórias por completo. Depois do assalto ao caminhão de gás e diante da negativa dos moradores sobre informações que levem aos ladrões, a polícia diz que "é sempre assim, ninguém viu nada, ninguém sabe de nada...".

E assim Buscapé vai narrando a "história" de um e outro. Segundo Lúcia Nagib, o termo "história", recorrente no romance e no filme (no filme vemos escrito na tela: "a história de Cabeleira", "a história do trio Ternura", "a história de...”) "não é casual ou inconsciente: ao contrário, mostra a premência, a absoluta necessidade de que as histórias por trás dos criminosos - dos quais de regra, na vida real, só se conhecem os crimes - sejam finalmente narradas." (NAGIB, 2006: 151). Deste modo, se o contraponto à tradição do cinema moderno brasileiro aparece na violência dos bandidos dos anos 80, retratados em Cidade de Deus, é no mesmo filme que Buscapé lança luz sobre um outro bandido, o bandido social. $\mathrm{Na}$ cena do assalto ao caminhão de gás, o trio Ternura, além de roubar o dinheiro do motorista, faz a distribuição de gás entre os moradores, é aqui o bandido social dos anos 1960. Retomada num segundo momento do filme, a cena de assalto ao caminhão de gás, situada agora nos anos 80, mostra que pouco importa aos bandidos - agora traficantes de cocaína - a distribuição de gás, quando estão mais preocupados com a fuga espetacular do outro grupo de traficantes e da polícia.

A partir dessa leitura de franca oposição entre as décadas, "dos 'românticos' anos 1960, com suas bocas de fumo, até o estabelecimento do mais rentável tráfico de cocaína" (ORICCHIO, 2003: 156), Lúcia Nagib faz uma distinção estética entre os três períodos (anos 60, 70 e 80), aludindo à fala do próprio Buscapé, que os divide em Paraíso, Purgatório e Inferno. No que seria a Idade do Ouro, anos 60, há o predomínio da luz dourada do sol, "que se liga ao alaranjado das ruas de terra batida de Cidade de Deus", com as tomadas aéreas, a câmera estável e os diálogos longos. Na segunda parte, o Purgatório, as tomadas de câmera internas e noturnas se tornam mais presentes, e com o crescimento do 
número de mortes, "a câmera se desvencilha do tripé e, no assassinato de Bené, as imagens se tornam indeterminadas pela posição pouco privilegiada da câmera e a fragmentação da luz estroboscópica do baile onde se dá a cena”. Por fim, esta última fase, que a autora pontua, sobretudo, a partir da vingança de Mané Galinha contra Zé Pequeno, mais sombria, caracteriza-se pela câmera na mão, “instável à cata de um objeto que se esconde em ambientes mal iluminados. Os cortes tornam-se ultravelozes e bruscos". (NAGIB, 2006: 152)

A construção do olhar de Buscapé nas diferentes décadas é devedora das mudanças sócio-políticas nesse arco de quase trinta anos que a narrativa abrange. Se o olhar antes estava voltado mais para a função repressiva do Estado ou mesmo para o abandono deste em relação à Cidade de Deus (Buscapé, quando nos mostra a chegada dos moradores, chama atenção para a omissão do Estado na CDD “porque aquilo lá fica muito longe do cartão postal do Rio de Janeiro"), entre o final dos anos 70 e meio dos anos 80 o olhar do narrador vai se voltar ainda mais para a engrenagem particular do bairro, sua autonomia em relação às leis do Estado e seu poder de coação (traficantes sobre os habitantes). É Buscapé também que nos transmite suas impressões sobre o trio Ternura, no passado e no presente ("Naquele tempo eu achava que os bandidos do trio Ternura eram os mais perigosos do Rio de Janeiro, mas eles não passavam de um bando de pés de chinelo").

A nostálgica e memorável cena do bandido Cabeleira sendo alvejado, em câmera lenta, num espaço geográfico horizontal, de terra batida, pobre, embora esperançoso e ainda por se fazer, ao som da canção "Preciso me encontrar", na voz de Cartola, é a morte do bandido social. Deste modo, o fascínio que a câmera da imprensa marrom exerce sobre Buscapé revela-se no momento em que o fotógrafo captura a imagem do Cabeleira morto: além de anunciar a morte do bandido, deflagra-se a vontade de se tornar narrador profissional no narrador por excelência da Cidade de Deus: "Tudo o que eu me lembro do dia da morte do Cabeleira é uma confusão de gente e uma máquina fotográfica, eu cresci paradão na ideia de ter uma máquina fotográfica". A narrativa do filme, mediada pelo olhar de Buscapé, passa ao corte mais frequente e, não raro, esse corte é acompanhado do ruído da câmera, como se cada piscadela do olhar, cada corte da montagem, representasse uma exposição e um captura da câmera fotográfica. No compasso da profissionalização de Buscapé como fotógrafo, intensificam-se os cortes 
fotográficos e a agilidade do filme, favorecendo outro tipo de percepção, fundamentando, inclusive, grande parte das críticas negativas que o filme recebe. É curioso que parte da crítica que atacou o filme tenha se filiado ao pensamento cinemanovista e, no lado contrário, tenha ocorrido o inverso, com detratores do Cinema Novo fazendo o elogio ao filme. A profissionalização do olho cinematográfico em Cidade de Deus, traduzida na trama pela ascensão de Buscapé como profissional da imagem, encontra numa crítica da revista Veja o posicionamento ideológico de ataque ao Cinema Novo, ao bandido social, e faz elogio do bandido perverso:

"Para ser bandido, é preciso uma arma na mão e algumas ideias na cabeça", brinca Buscapé, o narrador de Cidade de Deus. Já para fazer bom cinema, o velho mote de uma câmera na mão e uma ideia na cabeça é decididamente insuficiente. É preciso, antes de mais nada, um roteiro no papel. Não um punhado de anotações, mas um roteiro sólido e esquadrinhado à exaustão. Esse é o mais notório calcanhar-de-aquiles da produção nacional, que tem o hábito de deixar a sensação de que aquilo que foi rodado é um segundo ou terceiro rascunho. É um exemplo a seguir. Dos americanos. (BOSCOV, 2002)

A lente-relato de Buscapé, acompanhando as mudanças da Cidade de Deus, reflete ela própria sua percepção nas tomadas. Sua narrativa de edição inovadora e ruidosa deixa para trás o olhar que deitava sobre o bandido uma reflexão em suas condições sociais para captar os fragmentos das faces em closes com personalidades igualmente fragmentadas e sem solução. A fuga do bandido que precisava encontrar a si mesmo, como na música de Cartola, era interrompida pela polícia, representante do Estado opressor. Nos anos 70, a fuga do bandido Bené, uma saída de cena que buscava o isolamento em algum lugar paradisíaco com sua namorada, seria dessa vez interrompida por outro bandido. Se o projeto de ascensão de Buscapé começava a apontar uma saída pela tangente, vale dizer saída sem a ajuda de instituições governamentais, por outro lado, os habitantes da Cidade de Deus, antes sujeitos ao poder de fora, agora se viam acossados pelos vilões criados dentro de um feudo que se digladiava entre si, lutando pelo comando do tráfico de drogas. A briga entre Mané Galinha e Zé Pequeno, o Dadinho, "era entre o bonitão do bem e o feioso do mal". Mané Galinha, o bandido que estava ali por outros motivos, revelava na sua trajetória a decepção do narrador: "Parecia que, de repente, a Cidade de Deus tinha encontrado um 
herói” e, mais adiante: "Eu achava que Mané Galinha ia fazer a revolução na Cidade de Deus, mas deus tinha outros planos pra vida dele".

Ocorre que o abandono do ponto de vista macro apontou para o desejo do intelectual de não mais emitir veredictos sobre e para a sociedade. Paralelamente, a saída do intelectual total, na concepção de Pierre Bourdieu, tratada no primeiro capítulo deste trabalho, deixou falar vozes como a de Buscapé, que podemos interpretar até certo momento como intelectual de seu meio. Tratando das formas discursivas do romance Cidade de Deus, Paulo Jorge Ribeiro coloca a voz do autor como chave de uma intensa rede que procura dar visibilidade àqueles que "estavam no não-lugar destas discussões, aqueles que majoritariamente mais sofrem com as tragédias geradas pela violência urbana: os mesmos outros fantasmagóricos que vivem nas favelas e periferias das grandes cidades brasileiras" (RIBEIRO, 2003: 128). Num artigo em que discute alguns impasses da crítica cultural contemporânea, Ribeiro nos remete a uma passagem de Alberto Moreiras em que este fala sobre a ascensão da voz do outro como correspondente de um contexto político que superaria o literário (no nosso caso, o cinematográfico):

(...) a especificidade do testemunho e sua posição particular na configuração cultural atual depende de uma postura ou momento extraliterário, que poderíamos também entender como um momento de suspensão de toda simbolização, em um apelo direto à dor não exemplar, mas ainda singular, além de qualquer possibilidade de representação. (...) O testemunho é testemunho porque suspende o literário, ao mesmo tempo em que se constitui com ato literário: como literatura, é um evento limiar que se abre para uma ordem de experiência nãorepresentativa, drasticamente indicial (MOREIRAS, 2001 apud RIBEIRO, 2003: 127)

Ribeiro coloca em evidência, entretanto, os limites dessa voz mais democrática que rompe com a verticalidade discursiva. Esta passa a assumir perfis menos políticos e mais antropológicos. A voz de dentro de Buscapé, portanto, estaria mais absorta nas particularidades e nos perfis da Cidade de Deus e bem menos preocupada com os reflexos no tecido social da cidade. $\mathrm{O}$ bandido, menos implicado nesse tecido social, menos justificado por um conjunto de normas desfavoráveis a uma trajetória honesta, dentro da ordem instituída, estaria sendo mau sem fundamentos sociais. Caberia perguntar por que motivo o calcanhar de Aquiles da sociedade carioca, o tráfico que permeia todas as classes, estaria 
limitado a um único espaço geográfico. Portanto, o olhar-fetiche de Buscapé sobre o traficante dos anos 80 teria débito, dentre outros pontos, na sua narração limitada da primeira pessoa. Narração que, admitindo não poder falar da grande esfera, foca sua explicação num único ponto e trabalha no particular. Visto no outro polo, em Assalto ao trem pagador (1962), temos a abordagem do crime que, sem glamourizar, fetichizar e justificar, procura entender os marginais no todo social, mostrando que estes, longe da geração espontânea, "nascem e crescem melhor quando o solo é fértil e propício" (ORICCHIO, 2003: 192)

Admitindo-se, então, a voz particular de Buscapé, o filme Cidade de Deus, ainda assim, estaria esteticamente implicado em grande contradição. Sua narração, principalmente na segunda metade do filme, emite verdades absolutas quando o que deveria propor era a dúvida. É esse o motivo que coloca a linguagem de $O$ Homem que Copiava em sintonia com seu tempo. É esse o motivo que coloca Cidade de Deus numa linha de prepotência do olho onividente. Seus pontos de vista não são confrontados nunca, embora a montagem, no que se refere à velocidade dos cortes, esteja muito próxima da de $O$ Homem que Copiava. O que era dúvida neste, naquele a retórica e a repetição reafirmam a certeza.

Assim é que nenhum dos tantos recursos autorreflexivos utilizados no filme resulta em efeito de distanciamento, sendo o mais óbvio deles o alter ego do cineasta encarnado na figura do fotógrafo Buscapé, narrador onisciente do filme. Concebido como personagem intermediário, com trânsito entre as classes sociais, ele é também a autoconsciência do filme, sugerindo uma identificação com o próprio técnico na sala de montagem. Comportando-se como o detentor da verdade, organiza, com sua voz over, os fatos da narrativa, e requisita, a seu belprazer, o congelamento da imagem, seus retrocessos e avanços, os zooms e os planos gerais, denunciando assim o mecanismo da edição digital. (NAGIB, 2006: 155)

Para efeito de exemplo, a cena em que Buscapé testemunha a tomada da boca de fumo de Neguinho por Zé Pequeno é narrada três vezes, em três sequências, com três possibilidades de versões. A verdade, no entanto, é a mesma. O recurso linguístico aqui funciona mais como pirotecnia tecnológica e menos para instaurar a dúvida; ele mais afirma a onipotência de seu narrador, embora seja esse narrador, muitas vezes, identificado com um tipo de voz louvada extrafilmicamente, primeiro porque teria desistido da verdade universal e, em segundo, por ter as credenciais multiculturalistas do quem fala e do de onde fala. Longe de querer apontar lacunas na visada antropológica e/ou multiculturalista, o 
intuito é mais o de apontar as contradições do narrador, situado num espaço política e geograficamente contíguo, limitado, e, por isso, conflituoso.

De outro modo, ainda sobre o efeito que a edição dá ao filme, este agiria no sentido de provocar uma "impressão de realidade", dado que esta montagem, afinada aos preceitos da montagem clássica (Ibidem: 150), trabalharia em sua narrativa a transparência em oposição a um discurso de imagem e som reflexivos. Assim, mais uma vez, o que buscamos é evidenciar o quanto a montagem de Cidade de Deus é "amarrada" e o quanto sua narração, porque em primeira pessoa, supostamente relativizada, é centralizada. Se temos, como foi apontado anteriormente, um efeito de realidade via a narração presentificada da primeira pessoa, por outro lado, onde haveria, a partir do excessivo número de cortes de cenas, um tratamento de choque para alcance do realismo, na concepção de Eisenstein sobre a montagem, esse resultado não se efetiva. Menos do que a associação de ideias via montagem paralela, na segunda parte de Cidade de Deus, como exemplificamos com a descrição das cenas, a sutura reitera o discurso unívoco de Buscapé.

A mudança que se faz observar ao longo do filme no olhar do narrador, não raro foi acusada de espetacularizar a violência - argumento embasado nas tomadas em câmera tremida, exploração da imagem agressiva com encenações igualmente agressivas e, por fim, ou consequentemente, na falência de qualquer solução que viria via discurso e imagem. Para Ivana Bentes, uma das vozes de ataque mais polêmicas, propagadora do termo "cosmética da fome", o cinema utópico, reflexivo, dos anos 60 , tomado por ela como parâmetro, seria totalmente diferente do que se via em Cidade de Deus, "no qual a miséria é cada vez mais consumida como um elemento de 'tipicidade' ou vista como uma 'natureza' diante da qual não há nada a fazer” (BENTES, 2007: 194). Segundo Bentes, este cinema atual não estaria lutando contra os clichês do olhar exótico do estrangeiro acerca da miséria, onde tudo era interpretado como um estranho surrealismo tropical: "Somos capazes de produzir e fazer circular nossos próprios clichês, nos quais negros saudáveis e reluzentes e com uma arma na mão não conseguem ter nenhuma outra ideia além do extermínio mútuo" (Ibidem: 222).

Pelo viés que priorizamos nesta tese, o importante é ressaltar que Buscapé é o narrador que desliza entre classes. Do mesmo modo, sua mão segura de fotógrafo é a mesma que proporciona à classe média o deslizamento na Cidade de 
Deus e o retorno seguro, trazendo consigo Buscapé. Sua saída, já aparentemente garantida desde o início do filme, é colocada em xeque somente uma única vez. Enquanto os bandidos "se davam bem", Buscapé continuava "virgem, sem namorada e duro" e, sem ter outra saída. Surge, então, na tela a cartela "VIDA DE OTÁRIO”: o narrador nos mostra sua tentativa de ser honesto, trabalhando no supermercado até ser demitido, sob a acusação de facilitar o roubo de produtos por meninos da Cidade de Deus. Diz ele: “Trabalhei lá um tempão pra ganhar micharia... parecia até uma mensagem de deus" e ouvimos sua voz em off, simulando voz de deus: "Se liga aí, mané, honestidade não compensa" e mais uma cartela: "CAINDO NO CRIME". A impossibilidade de Buscapé se tornar um criminoso se dá menos pelas necessidades e mais por sua "boa índole". Segundo Ismail Xavier, o êxito que o personagem deseja ter pede uma postura pragmática, de ajuste às regras do mundo, com talento e esperteza, "sem tensionar a experiência com imperativos morais já sem sentido como bem mostraram a impotência do pai e o exemplo sórdido das autoridades (o que pensar da polícia?)" (XAVIER, 2006: 144). Lúcia Nagib, por sua vez, trabalhando a relação entre mar e utopia no cinema brasileiro, lembra que Buscapé é um dos poucos que tem acesso ao mar em todo o filme (com a exceção de Bené, que é assassinado, e os “cocotas"): "Enquanto imagem, no filme, [o mar] não passa de uma nebulosa silhueta no horizonte. O mar é apenas atingível para Buscapé, o alpinista social, que para tanto se aproxima dos "cocotas", ou seja, os brancos da Cidade de Deus" (NAGIB, 2006: 154).

O deslizamento do narrador entre as classes, porém, não se faz sem problemas. A pretensão de narrar para fora é explicitada antes de tudo por sua narração em primeira pessoa e seu domínio sobre a narrativa. Buscapé para o diálogo, avança, retrocede, explica novamente, elucida o significado dos termos utilizados e a hierarquia do tráfico. Nessa técnica manipuladora está implícito também seu distanciamento de onde narra, quando se esperava do olhar "de dentro" maior proximidade com o narrado. Cléber Eduardo afirma que é o narrador que coloca o filme na zona de risco de entendimento, "acenando com o cinismo final, que tanto pode ser condenado como problematizado enquanto artifício narrativo" (EDUARDO, 2005: 150). Ainda segundo ele, nesse viés de problematizar o filme enquanto artifício narrativo, Buscapé 
opta pela solução oportunista, não enfrentando em sua escolha um confronto com as forças corruptas a empestear seu mundo e, ao contrário disso, vampirizando as chagas sociais para firmar-se acima delas. (...) Um narrador que não se abala, que tira proveito dos estragos e narra orgulhoso o percurso de seu triunfo, sem questionar suas posturas, adepto de um pragmatismo da sobrevivência. É a legitimação de um vale-tudo. (Ibidem: 148)

Seria já o caso de pensar mesmo o personagem-narrador não como um apoio para o diretor, mas problematizá-lo enquanto sujeito "de dentro", questionando sua "autenticidade". José Geraldo Couto, num artigo elogioso ao filme de Fernando Meirelles, publicado na Folha de S. Paulo, ainda assim fragiliza o narrador de Cidade de Deus à luz do filme O Invasor (2001), dirigido por Beto Brant e com roteiro de Marçal Aquino:

Do ponto de vista político, por exemplo, pode-se questionar a apresentação da favela como um espaço de violência fechado em si mesmo, como se a droga fosse produzida e consumida toda lá dentro e o resto da sociedade não tivesse nada a ver com o tráfico. Invertendo o dito popular, o filme parece dizer: "Eles são pretos, eles que se desentendam". Nesse sentido, o contraponto natural seria "O Invasor", de Beto Brant, cuja conclusão é: "Estamos todos no mesmo barco". (COUTO, 2004: 196-7)

Em O Invasor, o plano ponto de vista, a câmera subjetiva de Anísio, o invasor da narrativa, antes se instaura sem aviso, sem pedido de credencial, para só em retrospectiva sabermos que é através dele que entrávamos no escritório dos empresários. O retrato que Anísio compõe de suas vítimas/algozes, os empresários, é tão ou mais vulgar que o seu próprio. No filme de Beto Brant, dada a invasão literal da narrativa por um personagem, em princípio, estranho a ela, torna difícil a distinção entre sujeito e objeto. Em Cidade de Deus, embora todo o discurso político esteja na direção de assinalar o nível de igualdade entre narrador e narrado, a saída de Buscapé coloca-o num patamar acima. As imagens espetacularizadas que compõem dos bandidos (Buscapé pede que estes façam pose para as fotos), ao final da trama, já sob a autoridade de fotógrafo do jornal, respondem simultaneamente aos anseios de visibilidade dos bandidos e aos anseios da classe média pelo bandido vilão, o bandido sem redenção. Eis a fala de Zé Pequeno diante de sua fotografia, na capa do jornal: "Dá uma olhada aqui, até que enfim os caras se tocaram que eu sou indigesto".

Mais uma vez, optando pelo caminho do pragmatismo, depois de ter flagrado com sua lente a prisão de Cenoura e de Zé Pequeno, a liberação desse 
último mediante suborno aos policiais e a morte deste mesmo Zé Pequeno, pela Caixa Baixa, grupo de meninos que assaltam, Buscapé opta pela publicação do corpo ensanguentado do vilão da história, retroalimentando o discurso midiático e a voracidade de seus consumidores. Sem entregar os policiais, Buscapé perpetua o estigma da Cidade de Deus, confinando-a ainda mais no feudo, com sua câmera assassina. A mesma câmera-fuzil que no cinema utópico intentou enfrentar a mídia e agir via estética da violência em nome da libertação nacional. Numa das últimas cenas de Cidade de Deus, Buscapé "dispara" com sua objetiva para o grupo de Zé Pequeno, ao mesmo tempo em que, por trás do narrador, sabotando a espetacularização, surge o bandido Mané Galinha disparando, agora tiros, e matando um soldado do bando oposto. A oportunidade de Mané se faz pela distração na pose para a foto. A visibilidade oferecida por Buscapé tem o preço da vida e sua câmera não salva mais.

Toda essa narrativa, que talvez se quisesse particular, mas universalizou o seu olhar, é entregue ao espectador do filme sob os auspícios da frase "BASEADO EM HISTÓRIAS REAIS". A partir da frase pretensiosa, surgem processos judiciais contra o filme. É previsível que tenham sido os moradores os autores destes processos, de modo que fica evidente o quanto a narrativa do real se distanciou do narrado. Os processos, extra-filme, obrigaram Paulo Lins, autor do romance, que ganhou segunda edição na esteira do sucesso cinematográfico, a modificar os nomes de praticamente todos os personagens. É curioso que a pretensão de colagem ao real tenha resultado ironicamente numa ausência de identificação no que se refere aos nomes dos personagens. Outras vozes "de dentro", como a do rapper MV Bill, reivindicaram em jornais e revistas a contrapartida do filme para com os moradores da Cidade de Deus. Buscapé, narrador fictício, por esse motivo saiu ileso. No entanto, sua narração na trama, embora ainda legítima, se problematizada, revela uma câmera que, se não mata, fere. 
5

\section{As vozes de legitimidade entre o documentário e a ficção}

5.1.

Capitão Nascimento e o choque de classes em Tropa de Elite

Comecemos com uma citação da literatura:

Limpei as joias. A velha tava no corredor, caída no chão. Também tinha batido as botas. Toda penteada, aquele cabelão armado, pintado de louro, de roupa nova, rosto encarquilhado, esperando o ano novo, mas já tava mais pra lá do que pra cá. Acho que morreu de susto. Arranquei os colares, broches e anéis. Tinha um anel que não saía. Com nojo, molhei de saliva o dedo da velha, mas mesmo assim o anel não saía. Fiquei puto e dei uma dentada, arrancando o dedo dela. Enfiei tudo dentro de uma fronha (...). (FONSECA, 2005: 18)

Lançado em 1975, o conto Feliz Ano Novo, do escritor Rubem Fonseca, levantava uma voz que fora até então mediada por narradores de classe média. Rubem Fonseca, também um escritor pertencente à classe média, resolvera, no entanto, dar voz ao bandido para levar ao limite sua narração. A ausência da mediação de um narrador burguês que condenasse o assaltante, abandonando o leitor diante da cena relatada pelo discurso seco e agressivo do outro de classe, contribuiu para a recepção polêmica do conto e lançou o livro na lista dos proibidos pela censura em todo o território nacional, como assinalou Vera Follain de Figueiredo (2003). Na edição de 2005, da Companhia das Letras, há na orelha do livro algumas das frases proferidas à época do lançamento: "Suspender Feliz ano novo foi pouco. Quem escreveu aquilo deveria estar na cadeia e quem lhe deu guarida também. Não consegui ler nem uma página. Bastaram meia dúzia de palavras. É uma coisa tão baixa que o público nem devia tomar conhecimento" (Senador Dinarte Mariz, na Folha de S. Paulo, em 7 de janeiro de 1977) ou "Li pouquíssima coisa, talvez uns seis palavrões, e isso bastou" (Ministro Armando Falcão, O Estado de S. Paulo, também em 7 de janeiro de 1977). Multiplicando os pontos de vista, no mesmo livro"19, o conto "Passeio noturno" é narrado em

\footnotetext{
${ }^{19}$ Ver a este respeito o livro Crimes do texto: Rubem Fonseca e a ficção contemporânea, de Vera Lúcia Follain de Figueiredo.
} 
primeira pessoa por um executivo de classe média alta, cuja distração, depois de um dia cansativo de trabalho, é tirar seu carro da garagem, dirigindo por ruas desertas e escuras, a procura de uma vítima. Colocando-nos em seu ponto de vista por uma narrativa serena, o motorista, com sangue frio, aguarda o momento exato e atropela a vítima, se possível para matar. E volta para casa, dá boa noite para a esposa e vai dormir.

Igualmente sob críticas, porém sem a censura da ditadura militar, o filme Tropa de Elite foi chamado por muitos de fascista. O problema, mais uma vez, era o ponto de vista. A polêmica levou o diretor José Padilha a se explicar nas muitas vezes em que foi entrevistado, recorrendo, inclusive, às definições exatas do termo "fascismo" para tentar mostrar o equívoco na aplicação do conceito. Com o problema das cópias piratas, os detratores do filme de Padilha ganharam mais argumentos contra o ponto de vista da narrativa em Tropa de Elite. Num debate promovido no campus da UFRJ, na Urca, um estudante argumentou que, da maneira como Tropa de Elite foi feito, ficaria difícil que pessoas menos privilegiadas entendessem a crítica: "Você não acha uma responsabilidade fazer um filme para uma massa que não entende?", obtendo a seguinte resposta do diretor: "Isso é uma visão elitista que acha que as pessoas não têm capacidade de entender. A elite acha que sabe tudo, mais do que todo mundo. A gente tem que ter muito cuidado com essa ideia de que uma elite cultural não pode falar com a massa". Na PUC-Rio, onde foram filmadas as cenas de aula do personagem Matias, um estudante reagiu, afirmando que José Padilha teria prejudicado a imagem da universidade. Segundo Padilha, na sabatina do jornal Folha de S. Paulo, o estudante indagava-o para saber o nome da pessoa da PUC que o acompanhou nas filmagens, no que o diretor respondeu ao aluno: "Por que, você vai botar a pessoa no saco?"

Em debate ocorrido no CCBB-RJ, com a exibição do filme, a professora e crítica Ivana Bentes comparou José Padilha ao diretor americano David W. Griffith e à diretora alemã Leni Riefenstahl. Como se sabe, Griffith é diretor de $O$ Nascimento de uma Nação (1915), filme que glorifica a escravatura, justificando a segregação racial nos Estados Unidos, e Riefenstahl é diretora de $O$ Triunfo da Vontade (1935), que legitimou o regime nazista na Alemanha. Ambos os diretores estavam em concordância com o discurso que seus filmes defendiam à época. Segundo Bentes, analisando o discurso dos personagens, consequentemente 
transpareceria o discurso de seus realizadores. É preciso lembrar, entretanto, que, diferente de Griffith e Riefenstahl, o diretor de Tropa de Elite, em todos os debates nos quais esteve presente, sempre condenou a atitude do polêmico personagem Capitão Nascimento. Padilha buscou em Tropa de Elite uma continuidade do seu filme anterior, o documentário Ônibus 174, no qual narrava o sequestro do ônibus, ocorrido na Zona Sul do Rio de Janeiro, no dia 12 de junho de 2000. Segundo Padilha, Matias seria o equivalente ao menino Sandro Nascimento, de Onibus 174, e seu processo de mudança no filme, elaborado dentro de um contexto violento e controverso, seria tão violento quanto o do personagem real. Lembremos aqui a frase do psicólogo social americano Stanley Milgran, que abre o filme Tropa de Elite: "A psicologia social deste século nos ensinou uma importante lição: usualmente não é o caráter de uma pessoa que determina como ela age, mas sim a situação na qual ela se encontra”. Para o crítico Luiz Zanin Oricchio, a história de Sandro Nascimento era tão inacreditável que não conseguiria ser vendida como um filme de ficção:

Se Sandro fosse um personagem de ficção, não teria sido tão bem inventado. Certo, havia a previsível infância miserável, o analfabetismo, a droga, a passagem pelo reformatório, depois por cadeias infectas, etc. nada que um brasileiro bem informado ignore. Tudo rotina. Mas ele não precisava ter presenciado a mãe ser assassinada a facadas quando era criança. Nem ser sobrevivente do massacre da Candelária, porque também já seria demais. Enfim, se esse personagem aparecesse num concurso de roteiros de ficção seria vetado porque inverossímil. (ORICCHIO, 2003: 184)

Desse modo, apontando para contextos extremados, Padilha justificaria a criação de Nascimento (e a trajetória de Matias) baseado num personagem verdadeiro, Sandro Nascimento. Em Ônibus 174 o que temos é a gênese do bandido. A política da voz do outro, embora falte a voz de Sandro para tentar dar sentido à trágica trajetória, é exercida aqui, mas não puramente como discurso em si. Ao modo de Notícias de uma Guerra Particular, de João Moreira Salles e Kátia Lund, que se lançou à tentativa de compreender os motivos da guerra do tráfico no Rio de Janeiro, ouvindo as várias vozes que faziam parte desse contexto, o documentário de José Padilha e Felipe Lacerda, sem tentar impor verdades, faz a conjunção das várias vozes do discurso e lança sobre elas um olhar macro, reconstituindo os lugares desses agentes para tentar entender o fenômeno de forma integrada. $\mathrm{O}$ foco, entretanto, é o bandido. 
Antes que a crítica conservadora, que sempre acusou o cinema brasileiro de colocar o bandido no patamar de herói, se manifestasse, Tropa de Elite surge para tentar compreender o outro lado. A filiação do filme advém dos dois documentários citados. Em Notícias de uma Guerra Particular está o policial do BOPE que dá origem ao filme de Padilha, o Capitão Rodrigo Pimentel, que à época se queixava de estar lutando numa guerra sem fim, numa guerra particular em que bandidos vingavam a morte de um traficante matando um policial do BOPE e vice-versa, num ciclo eterno de assassinatos:

O jovem que compra cocaína está alimentando este ciclo sem fim. Nós tentamos orientá-lo. Dizemos: o dinheiro com que você compra cocaína é o dinheiro para comprar o fuzil que vai matar o policial, com que vão assaltar o banco, com que vão fazer sequestro (...) A nossa guerra já se tornou particular. É uma guerra de polícia contra traficante. (...) Eu não vejo luz no fundo do túnel. Não é a ação policial que vai resolver o problema. Estou cansado...

O desejo de deixar o BOPE, manifestado por Rodrigo Pimentel, no documentário de João M. Salles e Kátia Lund, é, portanto, o argumento de Capitão Nascimento, em Tropa de Elite, assim como a manifestação, como dissemos, do diretor José Padilha de tentar entender esse outro policial, em relação ao documentário Ônibus 174. Embora relativize menos o discurso - não há a polifonia de Ônibus 174 - é preciso chamar atenção para a voz inusitada que surge no cinema brasileiro, a do policial (não exatamente a da polícia, como instituição). Cidade de Deus estaria apontando já o recuo da voz do bandido, no cinema, com a caracterização raivosa de Zé Pequeno e a respectiva mudança de olhar do narrador Buscapé sobre os bandidos dos anos 80; Notícias de uma Guerra Particular mostra no depoimento de uma moradora a mudança de perspectiva nos bandidos a partir dos anos 80, "Essa nova geração, essa juventude, eles têm um espírito suicida", denotando certa cisão do bandido com a comunidade. Também no depoimento de Hélio Luz, então chefe da Polícia Civil do Rio de Janeiro, a postura oscila entre o militante de esquerda, que vê a tomada do poder como sonho antigo, e o delegado de polícia, reconhecidamente a base repressora na situação. Fernão Ramos aponta no contexto de Notícias de uma Guerra Particular o momento de ruptura em relação à visão que se tem sobre o bandido: 
Noticias de uma guerra particular é o filme do momento de desarticulação e terror em face da nova realidade que embasa uma outra imagética do popular. Não mais o popular feio e sujo, a ser jogado debaixo do tapete, como aconselhavam à sociedade carioca os editoriais de Cinearte nos anos 1920. Também não se constitui naquele popular alienado, próprio ao contexto ideológico pré-64 do CPC/UNE, em relação ao qual o burguês-revolucionárioesclarecido podia, e devia, dar lição de moral. Também não é o popular que serve de elegia às tradições folclóricas ou é exaltado na beleza de sua cultura. A alteridade do popular, que emerge com força no final dos anos 1990, é uma alteridade agressiva e ameaçadora. É o popular criminoso ou criminalizado, pronto a atacar a sociedade legalmente constituída, sem pontes para o estabelecimento de uma linha de diálogo. (...) O sonho da concessão do poder ao outro popular, que nutriu a sensibilidade mais fértil da geração anos 1960, agora é realizado, mas em um contexto bastante problemático, gerador de dilemas existenciais contraditórios. (RAMOS, 2008: 224-5)

O entendimento de José Padilha seria, à luz de Notícias de Uma Guerra Particular, diante do depoimento do Capitão Rodrigo Pimentel, no limite do desespero com a falta de solução, distribuir a culpa entre as partes. Ademais, o consumo de drogas, motor narrativo na segunda parte de Cidade de Deus, ainda que nunca saibamos quem movimenta o tráfico dado o confinamento do enredo neste filme, é ressaltado em Notícias de uma Guerra Particular, demandando uma nova interpretação que inclua o aumento no consumo de drogas e o consequente aumento do poder de traficantes. A simplificada divisão classe média (representantes), povo (representados e oprimidos) e polícia (vilão) não dá conta do papel da classe média quanto se trata de pensar o funcionamento do tráfico. Culpabilizada, ela deixa de ser a portadora da voz no discurso do filme. Se em Cidade de Deus, com o narrador "de dentro", a ruptura do pacto narrativo com a classe média apenas se insinua, sem ser realizada, em Tropa de Elite, tal qual em outra chave fizera A Opinião Pública com seu espelho que perturba o método, o narrador desfere o golpe na cumplicidade entre diretor classe média, narrador classe média e classe média propriamente dita.

Nas palavras do personagem-narrador, o BOPE aparece em cena para acabar com as formas "pacíficas" de convivência entre o tráfico e a polícia: "A verdade é que a paz nessa cidade depende de um equilíbrio delicado entre a munição dos bandidos e a corrupção dos policiais. Honestidade não faz parte do jogo". Entre se corromper, se omitir ou ir pra guerra, Capitão Nascimento decide pela última opção. Seu discurso de potência e de policial incorruptível aparece a todo momento na narração em off: 
Eu não sou um policial convencional, eu sou do BOPE, da tropa de elite da Polícia Militar. Na teoria a gente faz parte da Polícia Militar, na prática, o BOPE é outra polícia, o nosso símbolo mostra o que acontece quando a gente entra na favela [caveira com arma na cabeça] e a nossa farda não é azul, parceiro. É preta. O BOPE foi criado pra intervir quando a policia convencional não consegue dar jeito. E no Rio de Janeiro isso acontece o tempo todo.

A imagem do rosto de Nascimento se congela e sua voz em off o apresenta: "Meu nome é Capitão Nascimento, chefiava a equipe alfa do BOPE. Eu já estava naquela guerra faz tempo e tava começando a ficar cansado dela”. A vontade do personagem de sair do BOPE, manifestada por Rodrigo Pimentel em Notícias de uma Guerra Particular, é o que gera aqui a busca por um substituto à sua altura: "Eu tenho que admitir, eu tava com pavio curto e a minha vida ficando cada vez mais complicada", "A guerra sempre cobra o seu preço e quando o preço fica caro demais é hora de pular fora, e foi aí que o Neto e o Matias entraram na minha história”.

A narração de Nascimento vai construindo para o espectador as personalidades de Neto e Matias, oriundos da Polícia Militar, mas competentes e honestos, como Nascimento diz que é preciso ser, e, portanto, necessários ao BOPE. Na dificuldade de fazer a escolha, o narrador coloca o dilema e a síntese: "Eu precisava da inteligência de um [Matias] e do coração do outro [Neto]. Se eu pudesse ter juntado os dois, a minha história não teria sido tão difícil”". A dificuldade a que o Capitão Nascimento se refere diz respeito ao excesso de confiança de Neto, no momento do embate, e à hesitação de Matias. Em determinado momento, diz Nascimento: "O Neto tentou consertar o erro, o Matias, não”. O erro de Neto foi ter desviado o dinheiro de suborno que ia para o Capitão da PM para consertar os carros quebrados na oficina da polícia. O erro de Matias foi ter tentado conciliar a polícia e a aulas de Direito, na faculdade. A narração de Nascimento vai dar prioridade ao conflito de Matias. Neto, personagem de pouca nuance na trama, será o escolhido de Nascimento, mas morrerá antes da substituição.

Matias é o personagem que concentra os maiores conflitos da trama, e talvez resulte disso a crítica a Nascimento como um personagem pouco nuançado, visto que, no primeiro corte (a primeira montagem na ilha de edição) de Tropa de Elite era Matias o narrador. A evolução de Matias equivale a de Sandro 
Nascimento, em Ônibus 174. Lembra aqui, novamente, a frase do sociólogo citado na abertura de Tropa de Elite, para quem "não é o caráter de uma pessoa que determina como ela age, mas sim a situação na qual ela se encontra". Assim, a narração de Nascimento vai antecipar os problemas de Matias: "Para o Matias, advogado e policial tinham as mesmas funções: defender a lei. Pra entrar pro meu batalhão, o Matias ia ter que cair na real". É assim que o personagem de Matias se debate entre a realidade da lei dura, no BOPE, e a lei relativizada, quando ouve as opiniões de seus colegas de classe, numa aula de sociologia, sobre a repressão que sofrem da polícia. Embora o filme tenha sido atacado por defender o lado da polícia, em detrimento de Michel Foucault, a cena abre espaço para uma interpretação dúbia. Diante das reclamações de estudantes que se sentem desconfortáveis com a polícia por não poderem acender seus baseados, Matias argumenta em favor da polícia. A polícia a que ele se refere, entretanto, já terá cometido aos olhos do espectador uma série de infrações, através da narração de Nascimento.

Não obstante, a crítica conservadora fez dessa cena o momento emblemático de uma suposta queda da esquerda e dos discursos falidos diante da "realidade" 20 . A revista Veja não perdeu a chance de se manifestar, fazendo do debate sobre Foucault o gancho para o dossiê Tropa de Elite. Uma das matérias, ancoradas na fala de Nascimento sobre "cair na real", trazia o título "A realidade, só a realidade" e fazia franca oposição ao pensamento de Michel Foucault. Segundo a revista, a cegueira da esquerda teria impedido que o cinema demorasse tanto tempo para mostrar a realidade como ela é, e os bandidos como de fato são:

A diferença é que esse filme o aborda pondo os pingos nos is. Bandidos são bandidos, e não "vítimas da questão social". Há policiais corruptos, mas também muitos que são honestos. Se existem traficantes de cocaína e maconha, é porque há milhares de consumidores que os bancam. Muitos desses consumidores, aliás, são aqueles mesmos que fazem "passeatas pela paz" e compactuam com a bandidagem para abrir ONGs em favelas. Por último, a brutalidade de alguns policiais pode ser explicada pelo grau de penúria e abandono que o estado thes reserva. (CARNEIRO, 2007)

Dando continuidade à leitura conservadora realizada pela revista Veja, Reinaldo Azevedo, em sua matéria sobre o filme, afirma que Padilha tinha sido

\footnotetext{
${ }^{20}$ Ver a esse respeito o artigo "Uma questão de ponto de vista: a recepção de Tropa de Elite na imprensa" de Vera Lúcia Follain de Figueiredo.
} 
libertado pelo povo, depois de ter sido sequestrado pelo Bonde de Foucault. Assim, a revista despendia tempo e espaço atacando as esquerdas e nada acrescentava de significativo para a leitura da obra de Padilha. Desse modo, a revista Veja mostrava também sua completa ignorância a respeito de filmes como Notícias de uma Guerra Particular, que já vinham trabalhando essa temática e nem por isso foram criticados pela esquerda.

Os comentários da Veja, como os de muitos outros veículos midiáticos, denotam, portanto, a abertura da narrativa do filme Tropa de Elite a permitir diferentes interpretações, à revelia das declarações do autor. Essa abertura se dá por dois vieses: o primeiro diz respeito à narrativa em primeira pessoa e ao ataque ferino deste narrador à classe média, até então colocada atrás das câmeras para olhar o outro e, por outro lado, à abertura extra-fílmica que se deu na proliferação das cópias piratas, rompendo o circuito esperado e controlado do filme, como observou Vera Lúcia Follain de Figueiredo (2010).

Sobre o primeiro aspecto, é preciso considerar alguns pontos que não estão no filme, mas se apresentaram como possibilidades de discussão. Segundo Padilha, Matias seria o narrador, o que talvez aumentasse o choque, já que acompanharíamos a transformação trágica pela voz do próprio personagem. E outro ponto para o qual o diretor chamou atenção diz respeito à última cena de Tropa de Elite. Nos últimos planos, Nascimento entrega a Matias a arma para que ele mate o bandido Baiano. Na mira do ponto de vista, quem olha Matias é baiano, mas não é este que vemos, é Matias. Essa construção coloca, então, o espectador no alvo de Matias. O tiro que o personagem dá e fecha o filme é o tiro dado pelo filme nos consumidores de drogas. Segundo o próprio diretor, tivesse Matias devolvido a arma ao Capitão Nascimento, sem ter dado o tiro, o filme estaria resolvendo o problema da sociedade. Não resolver o problema da sociedade é completamente condizente com o discurso a respeito do intelectual na contemporaneidade, que não deve mais se arrogar o direito de saber sobre os outros. Na contramão do que diz Cléber Eduardo, em artigo já citado, a respeito de alguns filmes que mascaram no personagem o discurso que o diretor não tem coragem de pronunciar, em Tropa de Elite a não-identificação entre diretor e narrador provoca na recepção uma nostalgia da tradição moderna do cinema brasileiro, quando a voz do personagem era a voz do diretor, como foi dito sobre Glauber em Terra em Transe. Essa narrativa aberta com um narrador inusitado no 
cinema brasileiro e mais a repercussão estrondosa do filme levaram o diretor Fernando Meirelles a afirmar ser José Padilha o “anti-Glauber”. Diz ele:

Compreendo perfeitamente essa ideia de o longa tentar ser neutro, de não se aliar ao protagonista, o Capitão Nascimento, mas também de não o condenar. É o antiGlauber Rocha. O Glauber era um cara que opinava em cada diálogo, em cada plano. E Tropa de Elite é o oposto. Essa estratégia tem muito mais impacto na sociedade do que qualquer filme que o Glauber fez. (MEIRELLES; PADILHA, 2008: 58)

O crítico de cinema Eduardo Valente, em artigo na revista eletrônica Cinética, diagnosticando no filme esse descolamento ideológico entre um e outro, coloca na discussão algo além da questão política do momento:

Embora a narração do personagem de Wagner Moura defenda e até certo ponto heroicize a atuação do Bope, é essencial entender que a voz de um personagem, mesmo que o narrador do filme, não é a voz do próprio filme (não custa lembrar o clássico exemplo do livro de Agatha Christie onde o narrador em primeira pessoa, aparente instância 'confiável' da narrativa, era ao final revelado como assassino). Estamos aqui frente à questão do ponto de vista que rege uma ficção - e é aí que Tropa de Elite se revela como uma ficção no sentido mais estrito: quando descola sua voz da voz do seu narrador na tela. (VALENTE, 2007)

No contexto de recepção do filme, entretanto, é justamente pelo descolamento entre diretor e personagem, operação reveladora de Tropa de Elite como ficção, que aparece a cobrança ética. Levada ao extremo, a política de dar voz ao outro, anunciada e praticada a partir dos anos 1970, em Tropa de Elite é alvejada pela crítica, indiferente ao fato de ser o filme uma ficção. Lembramos em capítulo anterior o filme Teodorico: imperador do sertão (1978), de Eduardo Coutinho, no qual a voz era concedida a um coronel autoritário, aparecendo de maneira muito escassa a intervenção do diretor. O que os filmes guardam em comum é a abordagem de sertões e favelas, locus problematizado nos mais variados matizes desde o Cinema Novo. Por outro lado, o que os difere é o fato de um ser ficção e o outro, documentário, mas essa distinção, se não serve para fazer separações radicais entre os dois filmes, precisa, ao menos, ser pensada. Pois que motivos fariam a crítica cobrar na ficção o que não se cobra com tanta ênfase no cinema documentário? Qual seria a diferença entre Padilha dar autonomia ao personagem Capitão Nascimento e Eduardo Coutinho dar voz à personagem 
Maria Pia, em Edifício Master, com seu discurso conservador, através da assertiva de que pobre é pobre porque é preguiçoso?

Sem querer responder às perguntas acima, poderíamos supor que talvez houvesse implicada na resposta a questão do realismo da primeira pessoa e o modo como Tropa de Elite retrabalha os fatos da realidade, colando seu narrador nesse real e perdendo a distância de um olhar de terceira pessoa, um olhar intelectual e menos entrelaçado. Assim, se o documentário se lança em direção à voz do outro, a ficção responde no mesmo movimento, recuando a voz do narrador intelectual para dar voz ao outro. Se o documentário se projeta num discurso imiscuído de detalhes subjetivos do personagem, dignos de uma fíç̧ão, como faz 33 ou Um Passaporte Húngaro, ou como faz propositadamente Jogo de Cena (2007), de Eduardo Coutinho, encenando verdades e desmascarando atuações cênicas; a ficção elabora para si imagens de tomada documental, numa visada micro-histórica. No caso de Tropa de Elite, é preciso recordar os bastidores, quando armas cenográficas foram roubadas por traficantes reais, mostrando que "o mundo do crime representado no universo ficcional extrapolou os limites impostos pelos enquadramentos da câmera e penetrou nos bastidores do filme, apontando para os tênues limites entre realidade e ficção" (FIGUEIREDO, 2008: 12). Há que se considerar ainda o público inesperado, que subverteu pelas cópias piratas a distinção entre ficção e documentário, reunindo filmes variados, antes pelas temáticas urgentes na sociedade (favela, tráfico, polícia). Filmes como Notícias de uma Guerra Particular, Quase Dois Irmãos e Santa Marta: duas semanas no morro viraram continuações seriadas (Tropa de Elite 2, 3 e 4).

Por outro lado, a marcação de diferença em relação ao cinema declaradamente político dos anos 60 talvez esteja na aposta de entreter e cativar o público. No caso de Tropa de Elite, o propósito de entreter o público confunde a crítica: ora se diz que as imagens são mais vinculadas ao documentário, ora a uma estética de filme policial de Hollywood. Esse fator gera um mal-estar, deixando desorientada uma crítica que lê o cinema brasileiro pelo viés do cinema moderno. Nesse sentido, para a leitura do cinema brasileiro a partir dos anos 90, Ismail Xavier rechaça as categorias geopolíticas implicadas no conceito de alegoria, que Fredric Jameson elabora para distinguir o cinema dos países centrais e os cinemas de países periféricos. Na tipologia elaborada por Jameson, a noção de "texto conspiratório" é associada à indústria cinematográfica dos países avançados, 
onde a única ordem que o cinema é capaz de sugerir é da conspiração planetária de fundo inacessível, quando se supõe que a complexidade do mundo e da rede de forças determinante da experiência se faz sentir nas alusões do filme policial, de espionagem, de intriga política, que envolve os serviços de informação, em que o herói se perde num labirinto porque ele não domina os canais de informação, mas que seria algo inteligível para alguém mais bem posicionado. (XAVIER, 2000: 107-8)

Por outro lado,

há o texto mais localizado, que expressa um inconsciente geopolítico ancorado num contexto nacional em que a representação alegórica, voltada para a figuração de uma nova forma de estar-no-mundo, alude ao sistema mundial e, ao mesmo tempo, expressa certo modo, local e específico, de estar inserido nesse sistema. (Ibidem)

O que faz com que essa dicotomia esteja superada, segundo Ismail Xavier, diz respeito ao modo como o cinema brasileiro de ficção tem elaborado os obstáculos para seus personagens dentro da ficção. Se antes o Cinema Novo compunha todo um sistema alegórico para pensar o ponto de partida, o problema, o trajeto e o alvo a se atacar (com nome e endereço do inimigo, "desigualdade", "capitalismo", "EUA", por exemplo), esquematizando agentes e resumindo as regras do jogo para quem quisesse jogá-las, o cinema contemporâneo, ressentido do recuo utópico, estaria flertando com o cinema de gênero policial, por exemplo, ao mesmo tempo em que trabalharia com a ideia de inimigo invisível e, por isso, digno da desistência dos personagens em tentar superá-los. Em Cidade de Deus, a ascensão de Buscapé como o único escolhido em sua comunidade, alçado por vias individuais e não por uma intervenção do Estado, por exemplo, e em Tropa de Elite, o uso da violência e a incompatibilidade entre lei e polícia, na figura do personagem Matias. Em resposta à tomada totalizante da sociedade, esse cinema contemporâneo estaria respondendo de modo individualizado às questões latentes no outro.

Nesse sentido, em Tropa de Elite, Matias não poderia ser visto como alegoria para pensar a impossibilidade de restauração do lugar do intelectual, já que o personagem não consegue conciliar teoria e prática - leitura de Foucault, tomada de consciência e ação prática na sociedade? Diz, então, Vera Follain de Figueiredo: 
O personagem, aliando a origem humilde à sua vocação para os estudos, teria o perfil para se tornar um intelectual engajado na reflexão sobre as questões sociais brasileiras, unindo experiência e teoria. No entanto, de possível futuro intelectual, em função das circunstâncias, é levado a abandonar a faculdade, enquanto a juventude dourada com a qual convive na universidade pode continuar os estudos, sem que estes contribuam, necessariamente, para que adquira maior consciência de sua responsabilidade na manutenção do status quo. (FIGUEIREDO, 2010: 157)

Em contrapartida, pode-se pensar que, no espaço extra-fílmico de Tropa de Elite, a constante convocação de José Padilha para falar na mídia sobre os mais variados assuntos, alguns fugindo ao tema do filme, estaria apontando para uma fala intelectual. Implicada em contradições entre o filme de temática social e a produção de cinema comercial, essa fala intelectual teria uma configuração diferente daquela do Cinema Novo, onde a tese estava apresentada na própria narração, prescindo do debate. A postura que Meirelles identificou como "antiGlauber", portanto, estaria no fato de, nesse novo esquema, o filme deflagrar o debate sem abrir mão de narrar uma história que seduza um público maior, como ocorreu em Tropa de Elite.

\section{2 .}

\section{As sub-representações do outro e o médico "doutor" de Carandiru}

Numa das primeiras cenas do documentário O Prisioneiro da grade de ferro, um rapper caminha pelo pátio da Casa de Detenção de São Paulo, o Carandiru, onde, sete meses antes da implosão do complexo penitenciário, o diretor Paulo Sacramento entregou câmeras aos detentos para que eles pudessem registrar imagens e histórias do próprio cotidiano da prisão. Com uma pequena câmera digital em mãos, o rapper avisa que "o filme começa agora" e que "Esse é o Carandiru de verdade, esse é o nosso autorretrato". Lançado bem próximo do filme Carandiru, de Hector Babenco, os o documentário não foi confrontado e vendido como resposta à ficção baseada no livro Estação Carandiru, de Dráuzio Varella. Mas a fala do rapper de que aquele que ele mostrará aos espectadores é o Carandiru de verdade suscitou na crítica, na imprensa e no público que assistiu aos dois filmes a ideia de contraposição ao discurso construído por Babenco. 
Primeiro, no sentido de caracterizar como ilegítimo o discurso da ficção. Depois, pelas vozes que narravam ambas as histórias. Ou seja: o "real", o "foi assim" ganhou força no documentário de Sacramento não apenas pela ilusão de verdade do gênero, mas também pela narrativa em primeira pessoa. $\mathrm{O}$ escritor Bernardo Carvalho diagnosticou o jogo de oposições durante uma sessão de pré-estreia do Prisioneiro. Após os créditos finais, ele conta que um estudante de história, emocionado, manifestou o seu agradecimento ao diretor "por permitir que a realidade do Carandiru viesse à tona, ao contrário de um filme como o de Hector Babenco"21, que teria, segundo o rapaz, encoberto a realidade com seus artifícios. A "visão de dentro" de O Prisioneiro da grade de ferro, a mesma que promoveu filmes como Cidade de Deus e $5 X$ favela - agora por nós mesmos, não deveria ser interpretada como efeito natural, continua Bernardo Carvalho, porque ela também fez parte de escolhas do diretor do documentário ${ }^{22}$. O escritor concluiu seu artigo, alertando para a tendência contemporânea da cultura brasileira de promover a cruzada contra o artifício das artes, que produz uma ilusão perigosa, por colocar "sob suspeita aquilo por meio do que o próprio filme de Paulo Sacramento pretende redimir os presos do Carandiru: o fazer artístico" (Idem).

Por isso, não é nosso objetivo colocar sob suspeita o filme Carandiru em oposição ao discurso supostamente livre de artifícios do documentário de Sacramento, mas cruzar os discursos fílmicos para discutir o papel do médico na ficção - narrador de fora, outro de classe em relação à massa narrada e mesmo de classe em relação a Dráuzio e a Hector Babenco - e problematizar o saber científico e a distância crítica para ver, à luz do novo realismo que se configura pela busca de proximidade do narrador com o narrado, seja pela estratégia da primeira pessoa, seja pela eleição de um personagem-narrador com o olhar de dentro do locus de narração. No caso do filme Carandiru, a opção será contrária, se dará pelo olhar de fora, o de quem teria menos autoridade para narrar histórias de prisão. A legitimação para que esse narrador de olhar cientificista possa imprimir sua história sobre o outro virá via cultura de massas. No livro $O s$ mistérios do Carandiru, Dinaldo Almendra faz uma minuciosa pesquisa sobre os

${ }^{21}$ CARVALHO, Bernardo. O artifício enquadrado. Disponível em:

$<$ http://www1.folha.uol.com.br/fsp/ilustrad/fq0807200316.htm>

${ }^{22}$ Essa tese paradoxal de uma arte livre de artifícios evoca, de certo modo, "a imparcialidade da câmera" ou o "fragmento de realidade bruta", preceitos de André Bazin que à época já não resistiam a algumas análises. 
desdobramentos midiáticos do massacre do Carandiru e os inúmeros discursos que surgiram a partir dele. No estudo, ele relembra as formas de legitimação da voz de Drauzio Varella nos veículos midiáticos, vendida como testemunha dos acontecimentos na penitenciária. E chama atenção para o fato de que outras vozes, como a de detentos que sobreviveram à invasão da polícia, não terem se sobrepujado à voz do médico. Em alguns casos, o aproveitamento do discurso da alteridade em programas de televisão de cunho sensacionalista serviu apenas para solapar a validade de testemunhos trágicos na tentativa de alavancar a audiência. É o caso de André du Rap, que em junho de 2001 esteve presente no programa Melhor da Tarde, da TV Bandeirantes, viu amigos serem fuzilados e presenciou diversas formas de tortura praticadas pela polícia. Confrontado no palco da atração com o deputado e capitão Conte Lopes, que afirmou que teria matado mais de 250 bandidos e que era favorável à pena de morte para marginais, Du Rap era questionado pela apresentadora Astrid Fontenelle se ele também era a favor da pena de morte. Apesar da resposta implícita na história de vida do ex-detento, o programa queria fazer falar no intuito de causar um bate-boca polêmico entre os participantes. Ainda como efeito colateral desse apagamento de vozes periféricas, o teaser trailer que vinha sendo exibido para antecipar o trailer principal de Carandiru, antes do lançamento do filme, tornava mais palatável o problema social, ao misturar dados díspares: "7 mil presos, 1 médico e 1 milhão de leitores". Chamando a atenção para o grande número de leitores de Estação Carandiru, de Drauzio Varella, o trailer tentava capturar novos fãs, que poderiam agora ver a versão cinematográfica. No subtexto, o pequeno vídeo diminuía a importância do número de detentos: "É como se, apesar da menção do número assombroso de presos e das imagens da cadeia, a referência ao presídio ficasse como pano de fundo. $\mathrm{O}$ destaque dado à quantidade de leitores faz com que a ideia de superlotação de um complexo penitenciário faraônico tenha sua importância diminuída" (ALMENDRA, 2011: 144).

Diante do sucesso do livro de Varella, outro ponto que desperta curiosidade é o jogo de atração e repulsa que o filme estabelece com seu texto de origem. Interessa-nos trazer esses dados para que entendamos, sobretudo, as interfaces da figura do médico como instância narrativa com Varella, com o narrador de Estação Carandiru, como o personagem fictício que no filme atende apenas pelo nome de "doutor," e com Babenco. O que deve ficar claro é que o 
personagem do médico paira sobre a narrativa, e não há dúvidas sobre o seu papel de mestre de cerimônias e de regente da história. O inconfundível lugar de destaque do médico está explícito, por exemplo, na entrevista que Drauzio Varella deu à edição 59 da revista "Cult", na qual o autor afirma que o sucesso do livro vem do fato de ele não utilizar a linguagem da cadeia. O crítico Jean-Claude Bernardet se vale desse dado para questionar o fato de a adaptação de Babenco ir no mesmo sentido. Como a fórmula do livro não se repete no filme - ou seja, não existe identificação entre o médico-narrador de Carandiru e o diretor Hector Babenco, como existe entre Drauzio Varella e seu narrador, médico como ele -, o crítico toma a figura do "doutor" na adaptação como um "anteparo, um mediador entre o narrador/realizador do filme e o objeto real, que são os presos, a vida na cadeia etc" (BERNARDET, 2003).

Por isto [ausência da linguagem da cadeia], o leitor se sente seguro, ele não é conduzido ao inferno interior da penitenciária. Drauzio, o narrador, faz transição suave para a classe média do que ele viu lá dentro do Carandiru. Ao ler o livro (ou ver o filme) esta classe média os toma como o inferno do outro. Já [Paulo] Sacramento [em $O$ Prisioneiro da Grade de Ferro] assume outra postura e mergulha no inferno. O médico-narrador do Babenco não é propriamente um narrador. Há algo mal resolvido ali. (...) Obviamente ele não é o alter-ego do diretor do filme, mas sim um escudo, um biombo. Ao mesmo tempo, ele não participa da ação. (Ibidem)

Embora seja evidente a tentativa de mimetização do médico do livro no filme, ela oscila com frequência nos produtos distribuídos à imprensa e veiculados para o público antes do lançamento e em materiais como os extras do DVD do filme. A construção da expectativa e do jogo de sedução da produtora do filme com o espectador vai ao encontro do sucesso editorial que chegará às telas dos cinemas. Daí, o teaser promocional curto e cheio de suspense informando apenas os números já citados aqui (7 mil presos, 1 médico e 1 milhão de leitores). É a estratégia para que o prestígio comercial do livro se desdobre em outra mídia. Por outro lado, interessa ao filme se descolar do autor do livro para que o cientista que poderá narrar as tramas da cadeia perca seu caráter personalista (focado na figura de um médico bastante requisitado na mídia, mas, ainda assim, a de um ser humano com nome, endereço, família, virtudes e defeitos) e ganhe um perfil universalista (a partir dos sentidos metafóricos que a persona de um médico e seu jaleco branco evocam), o que explica, em parte, a falta de referências ao nome do 
personagem, que atende apenas por "doutor" 23 . No making of do DVD do filme Carandiru, Drauzio Varella afirma que o diretor Hector Babenco tomou seus personagens e os fundiu, criando novos atores da ficção e novas histórias oriundas dessas fusões. Mais: Varella afirma que aquelas histórias, mostradas em imagens, não são histórias de ninguém - no sentido de liberar o cineasta de compromissos com a realidade e com eventuais detentos da vida real que tiveram suas histórias narradas nas telas, como ocorreu com os moradores da Cidade de Deus que se identificaram com personagens do filme de Fernando Meirelles. Dráuzio Varella avisa, ainda, que aquele médico, interpretado no filme pelo ator Luiz Carlos Vasconcellos, também não é ele - “nem aquele médico sou eu também”. No livro, o médico-narrador confunde-se com a do próprio autor, cuja experiência na maior penitenciária da América Latina é decorrente de seu trabalho voluntário para tratar, sobretudo, detentos portadores do vírus HIV e que desenvolveram a doença por conta das condições precárias da vida na cadeia. Mas ele sinaliza, no mesmo making of, que suas tramas também pertencem ao mundo da ficção:

Eu não tenho direito de chegar no livro e colocar uma história dessa, contada assim, de modo que alguém identifique quem foi essa pessoa, porque o cara não me contou isso pra colocar no livro, ele me contou isso porque eu sou médico e ele confiou no médico. Mas por outro lado a história pode ser contada e pode ser muito interessante. Então, como é que você conta uma história dessa? Tem que arranjar um disfarce que mesmo ele, se ele ler, não vai se identificar.

Assim, Babenco segue o mesmo curso de Drauzio Varella: "disfarçar" o peso do autor no filme, desdobrando as histórias do médico como este desdobrou os relatos dos presidiários no livro (ALMENDRA: 168). Entretanto, quando se trata de reivindicar para o filme um lugar discursivo autorizado, o cineasta costuma lembrar sua amizade antiga com o médico. Babenco conta que estava sendo tratado de um câncer por Drauzio Varella, que é oncologista. À época, Varella já tinha a experiência do tempo passado no Carandiru e distraía o cineasta com as histórias que ouvira dos presos. Segundo Babenco, ele foi o encorajador para que o médico escrevesse um livro sobre os detentos do complexo

\footnotetext{
${ }^{23}$ A questão da analogia da ciência com o universal e vontade de verdade reaparecem em outros discursos sobre o Carandiru. Assim como paira sobre a penitenciária a figura do "doutor" no filme de Babenco, o livro Aqui dentro páginas de uma memória: Carandiru anuncia em sua sinopse para o site da Livraria da Travessa a autoridade para narrar via figura ilibada do jornalista Percival de Souza, "que esteve sempre em contato com a lama humana sem jamais se macular" e que "interpola, aqui e ali, conceitos sobre o direito penal e nosso sistema prisional e raciocínios brilhantes de sua inteligência".
} 
penitenciário. Por esse motivo, ele seria "pai postiço" de Estação Carandiru e, por consequência, pai legítimo de Carandiru, que é o desdobramento do livro. "É como se eu tivesse dividido com você esse livro desde a sua concepção, de alguma forma me senti um pouco pai postiço daquele livro" ${ }^{24}$, disse o diretor, em entrevista a Drauzio. A lógica de autoafirmação de Babenco como grande narrador passa a fazer ainda mais sentido quando nos atentamos para o fato de que o cinema possui diversas instâncias narrativas (imagem, voz, música, montagem etc) que confluem para reforçar um discurso ou se dispersam para denotar contradições. Aliado ao caso específico de Estação Carandiru, temos um autor assumidamente situado dentro do próprio enunciado (são do próprio Drauzio Varella as histórias relatadas pelo médico-narrador), enquanto Carandiru remete à voz do médico, mas esta não encontra correspondência na voz de Babenco, que não tem sequer a identificação da profissão de médico com o personagem principal. Se levarmos ao pé da letra a tomada da voz pelo médico, constataremos que ela acontece em apenas três situações. A primeira situação é talvez a mais importante. Por ocorrer nos primeiros minutos do filme, é ela quem concede o salvo-conduto para que o "doutor" continue a fazer suas visitas à penitenciária e impulsione a narrativa fílmica. A autorização dada ao médico é, na verdade, a autorização para que Babenco possa contar a história. A primeira pessoa do médico, em seu monólogo interior, guarda a terceira pessoa do cineasta. Na cena em questão, deixando o presídio pela primeira vez, o médico ouve de um detento, antes que o portão atrás de si seja fechado: "Doutor, o senhor volta?". O questionamento fica sem resposta. O suspense, que provoca desamparo nos detentos, é desvendado parcialmente apenas para o espectador, quando o médiconarrador já se encontra no metrô, voltando para casa. "Eu sabia que muitos daqueles homens não tinham demonstrado clemência diante de suas vítimas, mas a sociedade tinha seus juízes, não me cabia julgar. Ao mesmo tempo, o que tinha eu a ver com aquilo? Havia duas escolhas: esquecer ou voltar". Na diegese, o retorno fica em suspenso até assistirmos ao médico adentrando mais uma vez pelo portão do pavilhão. Fora do espaço diegético, porém, a volta do doutor é a única possibilidade para que o filme se realize, tendo em conta seu papel de propulsor da trama, ainda que esteja nele escamoteada a figura de Babenco.

\footnotetext{
${ }^{24}$ Entrevista disponível em <http://drauziovarella.com.br/audios-videos/babenco-revela-comoteve-a-ideia-de-filmar-o-livro-estacao-carandiru/ $>$
} 
Aludimos aqui ao problema já apontado no filme Cidade de Deus do narrador intradiegético (Buscapé) que conta as histórias em primeira pessoa, logo tem visão parcial sobre os acontecimentos, mas possui uma contraditória onisciência em relação ao narrado. A virada antropológica focou sua crítica nos discursos totalizantes das grandes narrativas (as crenças na razão, na religião, no socialismo e na História, por exemplo) e Theodor W. Adorno, mesmo antes, já na década de 1950, desferiu um golpe contra a objetividade, apontando para a dissolução subjetiva do romance moderno e assinalando que "quanto mais firme o apego ao realismo da exterioridade, ao gesto do 'foi assim', tanto mais cada palavra se torna um mero 'como se', aumentando ainda mais a contradição entre a sua pretensão e o fato de não ter sido assim" (ADORNO, 2003: 57), no sentido de que o realismo, reproduzindo a fachada, apenas produziria o engodo. Em Carandiru, o que permite a penetração do narrador no local narrado é sua autoridade de médico, mas, ao longo da trama, essa função científica recua ou permanece no mesmo patamar que a do narrador-etnógrafo, que colhe as histórias. O mesmo ocorre no livro de Drauzio Varella. Partindo dessa constatação, esperaríamos do médico, que na penitenciária se converte também em antropólogo, um olhar microscópico. Mas, não se sabe se por sua perspectiva ou pela regência do narrador imagético (Babenco), a abertura do filme proporciona uma visão exageradamente abrangente e macro do complexo penitenciário. Bem do alto, vemos a cidade de São Paulo. A câmera desliza vagarosamente da direita para a esquerda até encaixar seu olho sobre o Carandiru. Ela, então, mergulha vertiginosamente. Mas, ao contrário do que acontece em $O$ Invasor, de Beto Brant, o espectador não mergulha por completo e, por isso, não tem seu ponto de vista aproximado ao de um detento, embora o "doutor" ainda não esteja presente na mediação do olhar entre a poltrona da sala de cinema e um detento. $\mathrm{Na}$ primeira cena pós-mergulho da câmera de fora para dentro do Carandiru, um jogo de mediações afasta o olhar do espectador de uma briga entre presos de diferentes celas. Em primeiro lugar, temos uma sequência na qual a porta da cela, com apenas uma fresta, se interpõe aos dois grupos. A cena é construída em oito planos sucessivos que alternam campo e contracampo. O primeiro plano mostra a confusão decorrente da lotação em uma das celas. Enquanto a briga acontece, o olhar do espectador implícito parte do lado oposto, entre ele e o conflito de detentos está a porta. No plano seguinte, o contracampo, a câmera está mais 
colada na fresta, de modo a retirar o nosso olhar, que agora parte de dentro da cela, do meio da confusão. Além da construção dos planos, que defende o espectador da arena, há um detento, Moacir, que se coloca como apartador da briga e se reporta ao diretor da penitenciária, Pires, quando este entra em cena no momento imediato à confusão. Atrás do diretor, está o médico, que aparece em cena pela primeira vez. Apresentado ao médico, Moacir mostra que o presídio é regido por regras próprias, que às vezes passam ao largo das normas oficiais do complexo penitenciário. "Pois é, doutor, o Moacir aqui está com problemas", diz, referindo-se ao desaparecimento de sua faca, que ele utiliza na cozinha. "Ainda tá faltando a faca da minha cozinha. Vou dar uma chance a quem pegou. Ou devolve ou morre um preso por dia. Eu vou pedir para as nossas visitas (o diretor e o médico) virarem de costas, porque tem ladrão envergonhado aqui. Quando eu virar de volta, eu gostaria muito de ver a faca", ameaça Moacir, e a faca aparece.

A partir daí, o médico-narrador passa a dominar o espaço narrativo e sua relação de poder com os presidiários passa a se dar por uma espécie de aura propiciada pelo saber científico. "Seu Pires, se eles entenderem como é que se pega Aids, pra mim já é um adianto. Eles pegam a doença aqui dentro. Transam com a mulher, transam com a namorada e aí a epidemia não para mais”. Na cena seguinte, já sentado à mesa, o médico dá início a um questionário dirigido aos presos. A alguns, ele pergunta como eles foram parar ali. Aos demais, ele quer saber se tem Aids, se usa preservativo, se fez teste de sorologia para detectar ou não o vírus. Nas três primeiras conversas entre médico e paciente, temos a construção do campo e contracampo, o "doutor" em foco fazendo as perguntas e a alternação dos planos para os detentos dando as respostas. A partir do quarto paciente, não temos mais a alternância de planos entre campo e contracampo, pergunta e resposta. Só vemos as respostas e, eventualmente, ouvimos casos "picantes" implicados nas respostas sobre a vida sexual de cada um deles. Nesses sete depoimentos não temos também nenhuma tomada lateral da cena pela câmera, em 180 graus, de modo a vermos enquadrados na imagem os perfis do médico e do paciente. Assim, as cenas de consulta, sem mostrar o médico, ganham status de depoimentos, de confissões destinadas não apenas ao saber do médico. Elas também incluem o espectador como ouvinte privilegiado de histórias privadas. Deste modo, Carandiru inscreve-se não apenas na seara das narrativas 
de crime $^{25}$, que exercem fascínio sobre o público. Ele se abre à curiosidade sobre a sexualidade alheia. Num dos depoimentos, um personagem homossexual, sentado ali para falar de sua saúde sexual e ouvir do médico conselhos para se prevenir contra doenças sexualmente transmissíveis, relata uma fantasia erótica a partir de um fato ocorrido com o responsável pela distribuição das refeições na cadeia. "Um dia desses pedi uma banana a mais para o moço que entrega o almoço. O safado disse que só me dava se eu desse um beijinho na banana dele. Fazer o quê? Sou louca por banana...”. O inquérito sobre a sexualidade ganha contornos de uma simples conversa, apesar de ser sempre o médico quem pergunta. Pelas histórias periféricas (casamentos, traições, fins de caso, homossexualidade, número de parceiros, modalidade sexual), o médico parece recolher informações para sintetizá-las num compêndio que cruzará as confissões com as doenças venéreas de cada um. Em caminho oposto, no documentário $O$ Prisioneiro da grade de ferro, o detento William Guimarães de Souza tem seu pedido de prisão em regime semiaberto negado após se submeter a um exame de personalidade elaborado pela Comissão Técnica de Classificação (CTC). A despeito da curiosidade sobre que respostas do presidiário fizeram com que a comissão desse parecer desfavorável, o diretor Paulo Sacramento opta pela inversão das expectativas, prefere enfocar a bateria vertiginosa de perguntas feitas pelo parecerista e manter a privacidade do prisioneiro. Ouvimos de William apenas a leitura do parecer. No filme de Babenco, a série de confissões com hábitos sexuais peculiares a cada um dos detentos terá continuidade através de outras entrevistas estabelecidas pelo "doutor”. Elas remetem à relação entre saber e poder na arqueologia de Michel Foucault, neste caso específico ao primeiro dos três volumes da História da Sexualidade. Em seu argumento central, o autor desmonta a tese de que a repressão teria suprimido a sexualidade a partir do século XVII, e, sobretudo, em séculos posteriores com a ascensão da burguesia e de seus novos hábitos. Segundo Foucault, a "vontade de saber" da ciência foi o

25 No prefácio do livro Os Mistérios do Carandiru, de Dinaldo Almendra, Vera Follain de Figueiredo retoma Thomas De Quincey ( $O$ assassinato como uma das belas artes, de 1827) para lembrar de um tempo "em que o crime transformado em discurso já não era mais o dos reis, como na tragédia, e também não se confundia com o crime popular dos folhetins baratos. Na primeira metade do século XIX, a burguesia já se apoderara ideológica e comercialmente das narrativas de crimes, estetizando-as de modo que pudessem conquistar uma camada mais ampliada do público". 
que possibilitou a catalogação de sentimentos, desejos e condutas sexuais e sua posterior ordenação.

A confissão foi, e permanece ainda hoje, a matriz geral que rege a produção do discurso verdadeiro sobre o sexo. Entretanto, ela se transformou consideravelmente. Durante muito tempo permaneceu solidamente engastada na prática da penitência. Mas, pouco a pouco, a partir do protestantismo, da ContraReforma, da pedagogia do século XVIII e da medicina do século XIX, perdeu sua situação ritual e exclusiva: difundiu-se; foi utilizada em toda uma série de relações: crianças e pais, alunos e pedagogos, doentes e psiquiatras, delinquentes e peritos. As motivações e os efeitos dela esperados se diversificaram, assim como as formas que toma: interrogatórios, consultas, narrativas autobiográficas ou cartas, que são consignados, transcritos, reunidos em fichários, publicados e comentados. Mas a confissão se abre, senão a outros domínios, pelo menos a novas maneiras de percorrer tais domínios. Não se trata somente de dizer o que foi feito - o ato sexual - e como; mas de reconstituir nele e a seu redor, os pensamentos e as obsessões que o acompanham, as imagens, os desejos, as modulações e a qualidade do prazer que o contém. Pela primeira vez, sem dúvida, uma sociedade se inclinou a solicitar e a ouvir a própria confidência dos prazeres individuais (FOUCAULT, 1988: 62).

Em Carandiru, a "vontade de saber" do médico não se limita à esfera da sexualidade. Ainda sob a perspectiva foucaultiana, seu olhar esquadrinhador, num ambiente que oferece perigos, dá algum conforto ao espectador implícito, sempre sob a sua guarda. Numa das cenas, o médico percorre lentamente um corredor interno do presídio. É noite, os detentos já estão em suas celas e o "doutor" vê sem ser visto. Enquanto ele caminha, ouvimos, fora do campo enquadrado pela câmera, gritos e falas indistintas vindos de uma das celas. Atraído pelo som do "barraco" (nome que os presos dão à cela), o narrador intradiegético se aproxima da porta e enxerga, através de uma fresta, homens deitados em suas camas e pelo menos meia dúzia de televisões ligadas em canais diferentes e em volumes variados. Seu exame minucioso coloca em paz o espectador, que já estava na expectativa de eminência de uma confusão. Mais adiante, o médico para na porta de outra cela, afasta discretamente uma cortina que guarda a privacidade do "barraco" e desvela a cena de um detento que cozinha a própria comida, recluso em sua solidão. Mais uma vez, o "doutor" vê sem ser visto. A extensão do panoptismo se dá, também, pelo clássico ponto de vista que permite a um vigilante, no esquema de centro penitenciário ideal desenhado por Jeremy Bentham em 1875, recolhido posteriormente por Michel Foucault em Vigiar $e$ punir. Dirigindo-se à saída do pavilhão, já no fim do expediente, o médico se 
detém no centro do pátio e dá um giro de 360 graus. Dali, ele observa as janelas de todas as celas, com roupas penduradas, a iluminação das lâmpadas incandescentes e as emissões luminosas das televisões que transmitem novelas, filmes e os noticiários.

No dia seguinte, de volta mais uma vez à rotina do Carandiru, o médico passa a ganhar mais confiança dos detentos. Sua autoridade de homem da ciência se fundirá à de etnógrafo, ouvinte que incita à fala. A partir desse ponto, em que o "doutor" ouve de Moacir a história do que fez para chegar ao Carandiru (e tudo o que o detento conta ao médico é mostrado ao espectador), todas as demais confissões serão narradas e mostradas. As confissões funcionam como a engrenagem da narrativa, são elas que possibilitam que a mostração de imagens se espraie para além do confinamento da penitenciária. Elas são o subterfúgio para que o filme não fique apenas no nível do discurso (do falar) e permitem que a narrativa se desloque para além dos muros do presídio. É como se o médico fosse o guardião do imaginário das inúmeras celas do Carandiru e só com a autorização dele, por meio da confissão, os detentos pudessem rememorar de modo mais completo (contando e mostrando) suas histórias. Prova dessa autorização para imaginar pode ser exemplificada na cena em que o detento Zico reclama que sua irmã de criação nunca contou a ele o que aconteceu "naquele dia" (em referência ao estupro sofrido pela menina que levou o irmão de Zico a matar os estupradores e ir para a cadeia). Curiosamente, desta vez, não vemos nada lá fora, o como aconteceu. Curiosamente, o médico, que sempre dá a ver o que está para além da penitenciária, também não está presente no momento em que Zico conta aos amigos de cela sua história. Desta forma, limitada ao confinamento, a voz da alteridade (a dos presos) fica subjugada à paciência do médico para ouvi-la, só quem pode dar forma e volume ao discurso é o “doutor". É só pelo médico e autorizados por ele que nos descolamos do seu ponto de vista para ver sob a perspectiva dos detentos. Por isso, embora o médico não tenha o perfil bem delineado de narrador intradiegético (sua voz é escassa, são apenas três monólogos interiores sobre o outro), reivindicamos o papel para este personagem, que carrega dentro do discurso fílmico o poder delegado por Hector Babenco, que vem a ser o grande imagista de Carandiru.

O acontecimento de maior importância - e que justifica a proliferação de narrativas sobre o Carandiru -, o massacre de 111 presos pela Polícia Militar, não 
é visto pelo médico, mas antecipado por ele na sequência anterior. À saída do pavilhão, o personagem-narrador repete um saber acumulado pela experiência da cadeia "do velho Chico", um detento experiente, após passar por outro preso, o Barba, que preparava um cigarro de maconha e garantira que aquele ali "é da paz, doutor". "Barba estava enganado. Faltava a ele a sabedoria do velho Chico, que havia me dito: 'cadeia em silêncio, muita obediência, sinal que alguma coisa vai acontecer'. Quinze dias depois, quando voltei ao presídio, só encontrei o vazio dos buracos das balas na parede". Após o trágico evento, o filme retoma as confissões e depoimentos de sobreviventes e testemunhas do massacre para a câmera. Desta vez, o médico não reaparece nem mesmo entre a fala de um e de outro detento. Mesmo com a inclusão do que podemos chamar de dêiticos, marcadores de discurso, o "doutor" pronunciado por um ou outro depoente, há uma fragilidade na construção do filme de tentar inserir o médico no contracampo, como ouvinte. Novamente, podemos classificar o personagem-narrador como anteparo para o que Babenco quer mostrar. No making of de Carandiru, o próprio diretor afirma que essas confissões gravadas para a câmera são a simulação de depoimentos "a um julgamento inexistente onde cada um contaria o que se lembra que aconteceu naquele dia. É um misto de depoimento com reflexão". Em $A$ narrativa cinematográfica, François Jost e André Gaudreault nos lembram que olhares direcionados para a câmera no cinema de ficção que preza pela transparência da linguagem clássica dão sentido documental ao filme ${ }^{26}$, e talvez seja mesmo essa a intenção de Babenco: emular a estética do gênero para legitimar como verdade o discurso do filme e dos depoentes. A essa altura do filme, Babenco parece dispensar a figura do médico para atingir o registro do documental. A legitimação das vozes dos presos, porém, não se dá sem choques e questionamentos. O desvio da função disciplinar do médico, como argumenta Dinaldo Almendra, faz com que o centro gravitacional que mantém o Carandiru no plano concreto da realidade seja deslocado para oscilar entre as esferas da ficção e da antropologia (Ibidem: 75). Nas páginas iniciais de Estação Carandiru,

\footnotetext{
26 "Nos primórdios do cinema, o famoso olhar para a câmera, que era do uso corrente, não devia ser particularmente notado pelo espectador, na medida em que o filme frequentemente reproduzia as condições das atrações do music-hall, que pressupunha a presença de um artista no palco de frente para o público. Foi somente a partir do momento em que o cinema começou a desenvolver histórias contínuas e que uma das suas pré-condições de funcionamento exigia a criação de um mundo diegético autônomo, que o olhar para a câmera foi banido de maneira sistemática" (GAUDREAULT; JOST, 2009: 63)
} 
Drauzio Varella informa que a proposta do livro não é provocar reflexão ou falar em nome do outro, politicamente, já que não se trata de "denunciar um sistema penal antiquado, apontar soluções para a criminalidade brasileira ou defender os direitos humanos de quem quer que seja" (1999: 10). Sendo assim, a diferença da voz e das condições da vida do outro, "não sendo elementos selecionados para o estudo sociológico e muito menos munição para a ação política, constitui-se em matéria sobre a qual se dobra o discurso localizado na fronteira entre a etnografia e a literatura de ficção" (ALMENDRA: 77). Enquanto a etnografia alimenta a literatura de ficção, esta impulsiona a autorreflexão do campo antropológico, como acontece em A Experiência Etnográfica: Antropologia e Literatura no Século $X X$, de James Clifford. Por essa razão, a estética documental dos depoimentos como denúncia do sistema se chocam com a proposta de ficção do livro e com as afirmações de Babenco de que sua opção não foi por despolitizar, mas também por não politizar. "Não estou aqui para ficar denunciando (...) Sou um artesão modesto que adaptou um livro que está dando certo. Estou tentando contar uma história para entreter o público. Acho que é o filme mais popular que eu já fiz"27.

Talvez essas opções explicitadas tenham sido algumas das razões para que $O$ Prisioneiro da grade de ferro seja apontado como o "Carandiru real", e talvez esteja aí a gênese da confrontação entre a ficção e o documentário. Ao utilizar da estética documental em favor de uma "reflexão" e da simulação de um julgamento, subtendendo que este consiste em punir os culpados, para depois admitir que não tem o intuito de politizar a abordagem, Babenco, de certo modo, fragiliza o discurso cinematográfico de Carandiru e também a figura do médico, ficando entre o assumido cinema de entretenimento e a tomada de posicionamento político controversa. Chama atenção que o filme de Paulo Sacramento reivindique não o etnógrafo, mas a persona científica de Drauzio ante a realidade dos presos. "Se tivesse quatro doutor Dráuzio aqui na Casa de Detenção, resolvia o problema. Porque o doutor Dráuzio é mééédico, médico que põe a mão no detento. Se tiver que por a mão em qualquer coisa, ele põe a mão pra saber o que é que a pessoa

\footnotetext{
${ }^{27}$ Depoimento dado a Mario Cesar Carvalho para o livro Carandiru: um filme de Hector Babenco. São Paulo: WidePublishing, 2003.
} 
tem", afirma um detento. Também as tomadas de câmera partem de um movimento inverso. É este o ponto nevrálgico que opôs um filme ao outro. Enquanto no próprio discurso cinematográfico dependemos do "doutor" e de Babenco para olhar os presos, o documentário de Sacramento opta pela provocação do ponto de vista inusitado. Na sequência que melhor traduz o espírito do Prisioneiro, um detento filma, da cela, um trem que passa no horizonte: "Aqui a gente tá tentando mostrar pra vocês mais ou menos a visão que a gente tem da cela. Lá vai o famigerado metrô, faz tempo que eu não pego um desse, hein? Acho que o sonho meu e da rapaziada que tá aqui é pegar esse metrô pra ir embora pra casa", explica, incluindo o espectador no seu discurso ("a gente tá tentando mostrar pra vocês a visão que a gente tem") e traduzindo, também, uma demanda de seus pares ("o sonho da rapaziada que tá aqui é pegar o metrô pra ir embora pra casa"). Revê também o seu passado, quando enquadra uma nesga da Avenida Paulista apenas para informar que ali comemorou muitas vitórias do Corinthians. Em seguida, outro detento-com-a-câmera chama à reflexão: "Espero que cada um de vocês possa parar por um minuto e imaginar como seria se você estivesse passando cinco anos da sua vida longe da família, longe de todos”. Outro prisioneiro estica o braço para fora da janela para capturar a própria imagem olhar parcial, anti-panóptico - em que ele pode representar a si próprio de dentro para fora e de fora para dentro. É simbólico que Paulo Sacramento tenha chamado o diretor de fotografia Aloysio Raulino para comandar o gesto de passar as câmeras às mãos dos 18 detentos que participaram de um curso de vídeo ministrado naquele estabelecimento prisional antes da produção do filme. Raulino talvez tenha sido o primeiro cineasta brasileiro a entregar a câmera a um personagem, um lavador de carros, para que filmasse seu cotidiano no curtametragem Jardim Nova Bahia (1971). A oposição que se instaurou no nível dos debates e da crítica entre Carandiru e O Prisioneiro da grade de ferro, desde a época de lançamento dos dois filmes, é resgatada aqui não para incorrer no erro de acreditar que o documentário permitirá vir à tona a realidade do Carandiru. Mas no intuito de questionar, na obra ficcional, a opção ética realizada, que criou uma super-representação vazia de um médico-narrador, um anteparo, como definiu Bernardet, apenas para falsear e esconder Hector Babenco, deixando, por motivos banais, a alteridade sub-representada. 


\section{3.}

\section{Negociação das vozes em 5X favela - agora por nós mesmos}

No filme Ladrões de cinema (1977), de Fernando Coni Campos, um grupo de favelados, a maioria composta por negros e mulatos, fantasiados de índios, roubam o equipamento de filmagem de uma equipe de cineastas norte-americanos que vieram ao Rio de Janeiro a fim de registrar o carnaval. $\mathrm{O}$ grupo volta à favela, o Morro do Pavãozinho, e discute o que fazer com o equipamento. Em princípio, os moradores não acreditam que possam reverberar o próprio discurso para além do morro. A opinião contrária à filmagem é defendida pelo personagem de Grande Otelo: "Por ideal, cansei de fazer samba de morro pra escola e ninguém nunca deu bola. Por ideal, fiz um argumento pra filmar e ninguém quis o meu argumento. Tu tem mais é que afanar aqueles trecos, filme, gravador, câmera, tudo aquilo, vender e me dar parte do dinheiro". Aqui, Otelo emula o seu temor às desilusões e experiências vividas por Espírito da Luz, também interpretado por ele em Rio, zona norte (1957), por conta das apropriações que o asfalto fez de seus sambas no filme de Nelson Pereira dos Santos. Ao se decidirem por fazer o filme com o equipamento dos americanos, os favelados recebem a ajuda de um etnógrafo francês visitante, que atende pelo nome de Jean-Claude Rouch (interpretado pelo crítico Jean-Claude Bernardet) e que lhes consegue negativo, além de oferecer uma rápida iniciação técnica sobre como filmar. $\mathrm{O}$ etnógrafo francês que ajuda os favelados saúda o filme como uma produção cinematográfica feita "pelo povo, sobre o povo e para o povo", acrescentando que ela servirá de material para sua tese. O projeto mobiliza o morro, que confere ao filme "o tipo de criatividade costumeiramente dedicada à preparação para os desfiles das escolas de samba" (STAM, 2008b: 414). Os cineastas neófitos reencenam a Inconfidência Mineira, tal qual um desfile de escola de samba de temas históricos ${ }^{28}$. Por ironia, são traídos e delatados à imprensa internacional pelo homem que no filme dentro do filme interpreta o traidor de Tiradentes. Os favelados chegam ao cinema algemados e assistem à pré-estreia algemados.

\footnotetext{
${ }^{28}$ Em 1949, o Grêmio Recreativo Escola de Samba Império Serrano tratou em seu enredo da Inconfidência Mineira com o samba Exaltação a Tiradentes.
} 
O filme de Coni Campos dá abertura a pelo menos duas leituras que se chocam e se complementam. A primeira resgata a trajetória de angústia do outro por não poder falar e ainda ter sua palavra capturada, sintetizada nas citações em abismo do termo ladrão (Ladrões de cinema se apropria do título do neorrealista Ladrões de bicicleta (1948), de Vittorio De Sica, os favelados se apropriam de negativos de cineastas norte-americanos e estes, por sua vez, se apropriam de um material autêntico do carnaval carioca, já que produzido pelo olhar de dentro, dando ao filme o nome de Ladrões de sonhos). Nesse sentido, o fato de favelados terem caído nas garras do "Mal imperialista" justifica uma recondução dos meios de produção ao cineasta intelectual, em tese o melhor curador das representações feitas do povo. Essa impossibilidade de filmar faz eco à voz da intelectualidade da esquerda dos anos de 1960: a de que o inimigo está lá fora (e não que ele surgiria da luta de classes em território nacional), de que, "neutralizadas as formas mercantis e industriais da cultura que lhe correspondiam [o imperialismo], e afastada a parte antinacional da burguesia, aliada do primeiro, estaria tudo pronto para que desabrochasse a cultura nacional verdadeira"29. Outro ponto que nos chama atenção diz respeito à perspectiva lançada por Coni de novas vertentes antropológicas praticadas na década de 70, materializada no filme pela entrada do etnógrafo Jean Rouch, homenagem ao cineasta francês Jean Rouch que se constituiu como uma das figuras de proa do cinema-verdade. Assim, Coni fez mea-culpa de sua geração em relação à ausência da voz do outro no discurso cinematográfico (sem deixar, com isso, de creditar a culpa ao estrangeiro pela captura do material) e projetou, não sem críticas, a figura do antropólogo como o mediador.

O exemplo serve para que possamos introduzir algumas questões que surgem com o processo de produção de $5 X$ favela - agora por nós mesmos. Mentor e executor do projeto, Cacá Diegues filmara 50 anos atrás Escola de samba, Alegria de viver, um dos episódios de Cinco vezes favela. No conjunto da obra, talvez seja de Diegues o curta-metragem que mais pesou a mão na cisão e na dualidade entre a luta política e a alienação, na visão do CPC. No filme, Dalva,

\footnotetext{
${ }^{29}$ Em Nacional por subtração, Roberto Schwarz, autor da citação supracitada, afirma que essa tendência a ver o estrangeiro como o perigo (algo descaracterizou a esquerda brasileira e sua identificação com o marxismo em decorrência da ausência da luta de classes entre proletariado e burgueses no território nacional) ocorre também nos movimentos nacionalistas de direita, com a denúncia do marxismo como alienígena [com a direita] imaginando talvez que o fascismo fosse invenção brasileira.
} 
uma militante sindical, é, a todo tempo, rechaçada por moradores da favela, que preparam o carnaval da escola de samba dias antes do desfile na avenida. Numa das poucas cenas que dariam a oportunidade de um respiro do filme, quando Dalva é cercada na saída do trabalho pelo marido, Ganazeu, e um grupo de crianças que carregam batuques, ouvimos, em off, uma voz que repreende a "distração" da personagem com o "barulho vazio" do carnaval. A voz ordena que Dalva deixe a conversa de lado e distribua os folhetos que conclamam o operariado. Essa voz, mais que a de um personagem que não aparece, é a voz do grande narrador, corporificada por Diegues e pelo CPC, que julga negativamente os atos dos personagens envolvidos com o carnaval e cuida para que Dalva não cometa os mesmos desvios. Já no ano seguinte, em duas cartas a Glauber Rocha, Diegues queixara-se do CPC, muito em decorrência das críticas negativas que seu curta-metragem recebera de todos os lados:

\begin{abstract}
Se, independente da minha vontade, eu me afastei do CPC foi porque mais ou menos isso (com sinal trocado) começava a acontecer. As pessoas deixam de realizar mesmo para cumprir tarefas marginais, se destroem e destroem o próprio sentido de sua função. Mário Faustino dizia certas coisas para mim que nunca esquecerei. Com toda a porralouquice dele (que era a maior centrada num homem só) ele sabia das coisas. Uma vez, falando dessas coisas, ele me disse mais ou menos isso: "num país subdesenvolvido é necessário ser comunista e impossível pertencer ao partido". É claro que ele se referia ao partido daquela época, sectário, burro, fechado, esquemático, dogmático etc. Mas vale também para certas coisas de hoje. Com isso eu fico sabendo: 1) Não se pode ser porra-louca sem estar cometendo um crime social; mas também 2) não se pode enquadrar em esquemas definitivos se em nossa sociedade está tudo se transformando com a rapidez de um segundo (...) Eu fiz uma merda de filme que todo mundo viu. Eu fiz um filme que ninguém viu que é razoavelmente razoável (Domingo). Mas fica mesmo é a merda (Escola de Samba). Poucos amigos me disseram isso: É UMA MERDA. É quase nada. Não adianta agora explicar o por que. Um dia estarei muito bêbado ao seu lado e lhe conto "thetruestry". Mas por enquanto considero chantagem fazê-lo. Meu filme, (que ninguém nos ouça) é um relicário de confusões, de desorganização, de desinteresse. O que eu só compreendi muito tardiamente. É fruto de situações concretas, mas é principalmente fruto de um processo de incertezas que eu sofri naquela época ${ }^{30}$.
\end{abstract}

O mesmo discurso da carta a Glauber, de que em nossa sociedade "está tudo se transformando com a rapidez de um segundo", além da vontade de revisão

\footnotetext{
${ }^{30}$ As cartas pertencem ao acervo pessoal de Diegues e constam da tese de Mariana Barbedo, intitulada O Realismo crítico de Carlos Diegues no cinema moderno brasileiro. O artigo está disponível no endereço $<$ http://www.snh2013.anpuh.org/resources/anais/27/1364654947_ARQUIVO_MarianaBarbedo .pdf $>$
} 
do olhar do filme de 1962, são alguns dos motivos enumerados por Diegues para fazer surgir o novo projeto. O hábito de estar sempre no lugar de fala fez, inclusive, com que o cineasta desse à refilmagem o subtítulo "agora por eles mesmos", corrigido posteriormente para "agora por nós mesmos" pelos diretores numa conversa com o agora produtor e coordenador geral do projeto. "Me dei conta de que, mais uma vez, eu estava me colocando do lado de fora, e o filme é nosso, foram eles que corrigiram o título"31, disse Diegues, durante entrevista ao programa do canal Multishow Conexões urbanas, apresentado por José Júnior. O apresentador da atração é também diretor do AfroReggae, uma das organizações não-governamentais onde ocorreram as oficinas de roteiro e de onde saiu uma das cinco equipes para as filmagens de $5 X$ favela. As chamadas para as cinco oficinas tiveram 680 jovens e adultos inscritos, todos oriundos das favelas. $\mathrm{O}$ trabalho de formar as cinco equipes foi centralizado pelas ONGs Cidadela/Cinemaneiro (Linha Amarela), Central Única das Favelas/CUFA (Cidade de Deus), Observatório de Favelas (Complexo da Maré), Nós do Morro (Vidigal) e AfroReggae (Parada de Lucas), escolhidas, ainda segundo Diegues na entrevista para o Conexões urbanas, "em função do valor que essas ONGs têm no mercado cultural”. Da triagem, 240 alunos participaram das oficinas. Destas, saíram 90 alunos selecionados para a equipe técnica, 40 alunos selecionados para o elenco e sete diretores para os cinco curtas-metragens que compõem $5 X$ favela - agora por nós mesmos. Diegues esclareceu também que a escolha dos diretores se deu em função do destaque de cada um deles nas cinco oficinas em diferentes localidades da cidade e do currículo de cada um no ramo do audiovisual ${ }^{32}$. Entrevistado por José Júnior, Rodrigo Felha, que codirigiu o episódio Arroz com feijão, narra uma situação de seleção diferente. Ele conta que estava trabalhando numa produtora, no bairro de Santa Teresa, no Rio, e recebia insistentemente ligações do mesmo número havia vários dias. Quando resolveu atender, era Cacá Diegues no outro lado da linha. "Então, Felha, é o seguinte: sabe o Cinco vezes favela, de 1962? A gente vai fazer um cinco vezes favela, mas agora por vocês mesmos. Eu quero que você faça parte desse projeto e dirija uns episódios. E aí?”, conta Felha, acrescentando que aceitou o convite imediatamente. Felha tem experiências

\footnotetext{
${ }^{31}$ Disponível em $<$ https://www.youtube.com/watch?v=D_kBvA8A-uY $>$

${ }^{32}$ Entrevista-de-Cacá-Diegues-disponível$\mathrm{em}<\mathrm{http}$ //www.saraivaconteudo.com.br/Entrevistas/Post/10067>
} 
anteriores ao projeto, como a atuação como câmera e editor do documentário Falcão, meninos do tráfico (2006), produzido por Celso Athayde, fundador da CUFA, pelo rapper MV Bill e que mostra a participação de jovens no tráfico de drogas dentro das favelas.

Durante as oficinas que precederam as filmagens dos cinco curtasmetragens, os selecionados assistiram a aulas e conferências de 22 professores e 12 palestrantes. A aula inaugural foi dada pelo igualmente "mestre inaugural" Nelson Pereira dos Santos, nas palavras de Cacá Diegues. Nelson é considerado precursor dos princípios que guiariam o Cinema Novo. Além dele, nomes tarimbados do cinema brasileiro, como Lauro Escorel, Walter Lima Jr., Ruy Guerra, Walter Salles, João Moreira Salles, Cesar Charlone, Daniel Filho, Fernando Meirelles, Marcos Flaksman e Dib Lufti orientaram os futuros executores do projeto $5 X$ favela. Sem esquecer que cinema é também mercado, Diegues convidou Manoel Rangel, presidente da Ancine, para falar sobre a gestão do cinema brasileiro. No processo das filmagens dos curtas, houve preocupação, também, com a preparação de elenco. Esta tarefa foi entregue à Camila Amado, figura igualmente renomada da dramaturgia brasileira. Janaína Diniz Guerra, que já fez assistência de direção para os filmes de seu pai, Ruy Guerra, e para Diegues, também deu sua contribuição aos diretores do filme. A divulgação do filme não foi menos cuidadosa e estratégica. A produção contratou a assessora de imprensa Gilda Mattoso, que está no ramo há mais de 30 anos, tendo trabalhado com boa parte dos artistas da Música Popular Brasileira, dentre os quais se incluem os tropicalistas Caetano Veloso e Gilberto Gil e os compositores Vinícius de Moraes e Tom Jobim. Outro cuidado no campo dramatúrgico foi a escolha de Rafael Dragaud como coordenador de roteiros. Dragaud é profissional da TV Globo e redige textos para os programas Amor \& Sexo, Fantástico, Caldeirão do Huck, entre outros. Ele também atua no cinema e é roteirista dos filmes Minha mãe é uma peça, Os Penetras, Mulheres, sexo, verdades, mentiras, $5 X$ Pacificação, Primo Basílio e Nenhum motivo explica a guerra, além de ter produzido Falcão: meninos do tráfico. Um fato curioso quanto ao nome de Dragaud é que os roteiros dos cinco curtas surgiram das oficinas com moradores das cinco favelas, segundo entrevistas dadas por Cacá Diegues, mas na edição de 2010 do Festival de Paulínia, em São Paulo, foi ele, Dragaud, quem recebeu o prêmio de Melhor Roteiro e ganhou visibilidade em praticamente todos os 
veículos da chamada grande imprensa, sendo o único roteirista citado nominalmente em diversas matérias jornalísticas dos maiores jornais, sites e revistas.

Diante de tantos nomes conhecidos da produção cultural brasileira nas últimas décadas, cabe a nós questionar qual foi o espaço dado aos cineastas de $5 X$ favela-agora por nós mesmos. Em outra direção, podemos pensar ainda qual foi o grau de permanência do alto cinema brasileiro, formado por nomes que figuram numa restrita lista de privilegiados sujeitos que filmam. A iniciação dada pelo panteão do audiovisual nacional aos novos diretores remete ao etnógrafo de Ladrões de cinema que ensinará aos favelados do Morro Pavãozinho o manejo dos equipamentos de imagem e som. Em sua análise do campo literário dentro do campo do poder, Pierre Bourdieu definiu essa categoria como o espaço das relações de força entre agentes ou instituições que têm em comum "possuir o capital necessário para ocupar posições dominantes nos diferentes campos (econômico ou cultural, especialmente)". Nesse lugar de lutas, estão detentores de poderes diferentes que "têm por aposta a transformação ou a conservação do valor relativo das diferentes espécies de capital” (BOURDIEU, 1996: 244). Partindo desta premissa, colocaríamos de um lado o capital social e humano que pode ser fornecido pelos moradores das cinco localidades, a fim de que possam legitimar o discurso fílmico a partir do olhar de dentro (dado muito realçado pela crítica especializada à época do lançamento de Cidade de Deus, de Paulo Lins), e, do outro lado, o intelectual de classe média destituído (no caso de Diegues, autodestituído), mas que busca meios para ir ao encontro do outro e propor a parceria na realização da obra. Na entrevista ao Conexões urbanas, o diretor Rodrigo Felha é questionado, quase que retoricamente, se já passou pela situação retratada no seu curta-metragem (o filme aborda a história de um menino que tenta arrumar dinheiro para comprar um frango para a família). A resposta: "eu sei o sentimento dessa criança, isso acontece comigo também. A gente às vezes tem que tirar daqui para pagar uma outra conta ali”, relata. Já Diegues, numa entrevista concedida em janeiro de 2015 ao programa Roda Viva, da TV Cultura, reiterou, meia década depois do lançamento de $5 X$ favela, que a classe média continua sendo a detentora dos meios, desde a produção à exibição, e também a única que assiste a filmes feitos sobre o outro e, em tese, para o outro: "No Brasil, o cinema até hoje é de classe média. Hoje em dia quem que entra num cinema pra 
ver um filme desses? Você tá fazendo um filme pra mudar a imagem do povo sobre si mesmo, mas este mesmo povo não vê o filme".

A autocrítica, porém, não impede que haja, de fato, uma negociação entre as partes para se estabelecer o grau de concessão à voz. Não queremos (nem caberia) aqui reivindicar nenhum tipo de pureza do discurso dessa alteridade que seja excludente tanto do mercado quanto de seus interlocutores no projeto, mas discutir procedimentos acerca do filme. André Malraux, no famoso ensaio Esboço de uma psicologia do cinema, leva numerosos parágrafos justificando os motivos para que o cinema seja considerado uma arte, numa época em que cineastas e teóricos buscavam legitimação cultural frente às demais artes, mas sua última frase, longe de colocar tudo a perder, mostra o quão complexas são as relações de produção do filme: "De qualquer forma, o cinema é uma indústria", conclui ele. Ainda assim, como o intuito aqui é problematizar o processo de produção e os resultados apresentados por $5 X$ favela, não utilizaremos o argumento final de Malraux como muleta. Embora o cinema seja indústria, há propostas estéticas que tentaram passar ao largo do capital financeiro, trabalhando com orçamentos relativamente baixos. Ademais, gostaríamos aqui de cotejar as propostas políticas do filme original e da refilmagem, para refletir sobre o modo como elas são levadas às telas.

À luz de Cinco vezes favela, a refilmagem de 2010 é uma produção bem mais ambiciosa, no que diz respeito aos valores investidos, aos atores sociais envolvidos e ao alcance pretendido. O filme, uma coprodução da Luz Mágica, de Cacá Diegues, com a Globo Filmes, teve custo de R \$ 4 milhões (metade do que custou Cidade de Deus) e foi patrocinado via Lei do Audiovisual, pela Ambev e pelo então bilionário Eike Batista, que vinha, com a ajuda eufórica da mídia, da Prefeitura do Rio e do Estado do Rio de Janeiro, tentando se firmar como o grande empreendedor social e chegou a usar o nome do filme diversas vezes para se colocar como mecenas de projetos culturais. No caso do filme de 1962, os recursos saíram do governo federal, graças à mediação de Ferreira Gullar, que trabalhava no governo e se tornou entusiasta do CPC. Os cinco cineastas de classe média também tiraram dinheiro do próprio bolso para custear o projeto, que totalizou, em valores corrigidos para a moeda atual, $\mathrm{R} \$ 200$ mil, ou a vigésima parte do orçamento de $5 X$ favela - agora por nós mesmos. Chama atenção, também, que o novo projeto tenha sido executado em película, e não com câmeras 
digitais. Em entrevista para o Festival de Cannes, na França, onde o filme foi exibido, Diegues narrou sua experiência de dar aulas em favelas em parcerias com as ONGs na década de 90 e contou que foi testemunha da emergência "de uma nova geração de cineastas que filmavam com celulares e câmeras mini DV. Perante o talento deles, disse-me que tinha chegado a hora de realizar um longametragem sério com eles ${ }^{{ }^{33}}$. Inferimos a partir da declaração do cineasta que a concessão estética, neste caso, foi feita pelos cineastas que surgiram das oficinas. Vale lembrar aqui a experiência de Silvio Tendler, que costuma ser acusado por críticos mais afinados ao cinema de viés antropológico de centralizador do discurso fílmico e expositor de teses sociológicas. No filme Encontro com Milton Santos, Tendler constrói a lógica de que o avanço da globalização provoca antídotos de resistência contra ela mesma, e dá como exemplo um grupo de jovens de Japeri, na Baixada Fluminense, que faz releituras do folclore local por meio de narrativas audiovisuais utilizando câmeras digitais simples (modelo cybershot) e cabos de vassoura como tripé. Tratando-se de uma grande produção, não seria o caso de $5 X$ favela - agora por nós mesmos, mas o exemplo de Tendler ajuda a pensar em alternativas estéticas que não sejam a da imagem limpa que vemos nos cinco curtas-metragens.

Mas, diferentemente da proposta política dos documentários de Tendler, abertamente contestatórios do sistema econômico vigente, o projeto $5 X$ favela agora por nós mesmos trabalha no limiar entre a criação dos novos atores sociais e a negociação com a política e estética do atual cânone cinematográfico que, de modo geral, tem sido a de não propor rupturas. Basta lembrar que a luta dos intelectuais do cinema dos anos 60 era proto-revolucionária e anticapitalista. $\mathrm{O}$ próprio surgimento do $\mathrm{CPC}$ da UNE, que gerou Cinco vezes favela, é desdobramento das insatisfações de alguns membros do Teatro de Arena diante do perfil do público espectador majoritariamente composto por universitários de classe média nas apresentações. O CPC, talvez levando como dogma a máxima de Frantz Fanon de que "todo espectador é um covarde", queria atingir as massas e fazer a cabeça do proletariado para que este deixasse a posição de passividade da sala de projeção a fim de fazer a revolução social nas ruas. Cinco vezes favela tentou falar sobre o oprimido e para ele. A equação de $5 X$ favela - agora por nós

\footnotetext{
${ }^{33}$ Entrevista disponível em < http://www.festival-cannes.com/pt/theDailyArticle/57652.html $>$
} 
mesmos é outra. Diretores de cinema oriundos de favelas desassistidas pelo poder público querem falar sobre os mesmos excluídos. Mas querem se fazer ouvir não apenas entre os pares, como também pela classe média, maior frequentadora das salas de cinema. Não há cisão de classes, tampouco crise de consciência com os patrocínios de grandes empresários e do capital financeiro internacional. O fato de oficinas culturais serem mantidas por grandes nomes outrora vistos como os opressores do "povo", como é o caso da Fundação Ford subvencionando projetos de uma das ONGs, não representa um problema e se reflete diretamente na temática dos curtas-metragens da produção. Líderes comunitários não repudiam o capital, lutam pela inclusão. Nesse sentido, as conquistas almejadas pelos personagens nas tramas não têm a intenção de irradiarem em nível macro. Nos já citados termos de Ismail Xavier, são manuais de sobrevivência e de ascensão.

A saber, o primeiro curta da série, Fonte de renda, mostra os percalços vividos por Maicon, um jovem que precisa se dividir entre o trabalho e a faculdade de Direito numa universidade federal. Em sua trajetória, ele encontra uma saída provisória para conseguir pagar suas passagens de ônibus, fazer fotocópias dos textos que devem ser lidos, comprar livros caros e ainda ajudar em casa. Seus colegas de classe, todos oriundos de classe média alta, pedem que ele compre drogas na favela. Maicon faz a ponte, mas logo percebe que esse não é o melhor caminho. No final, o jovem é laureado com a perspectiva de melhorar de vida ao receber seu diploma universitário. No segundo curta, Arroz e feijão, um menino ouve queixas do pai de que só come arroz e feijão todos os dias e tenta conseguir dinheiro para comprar um frango. Os curtasConcerto para violino e Deixa voar abordam o cotidiano de violência. No primeiro, um policial recorda sua infância ao lado de um amigo, agora traficante que ele está prestes a capturar. No segundo, um adolescente precisa recuperar a pipa de um amigo que caiu no outro lado de favela dividida por um valão. No outro lado, outra facção domina o território. O enredo é de superação: o menino atravessa e constata que a convivência não é totalmente impossível. O último curta-metragem, Acende a luz, considerado o melhor pela maioria dos críticos, mostra moradores sem energia elétrica em suas casas na véspera do Natal. Primeiro, eles usam a força para reter e evitar a saída do técnico da companhia de luz da comunidade até que ele resolva o problema. Mas a amizade que os moradores criam no curto espaço de tempo com 
o profissional faz com que ele permaneça ali pela própria vontade para sanar a falta de luz na favela do Vidigal.

Em diversas ocasiões, sobretudo em pré-estreias para apresentar o filme ao público, os diretores citavam Cidade de Deus e Tropa de Elite como contraexemplos das histórias que seriam exibidas na tela. Para estes sete cineastas, os filmes de Fernando Meirelles e José Padilha não representavam a favela. Diretor do episódio Concerto para violino, Luciano Vidigal disse, durante o Festival de Paulínia, onde o filme ganhou sete prêmios, que Cidade de Deus é o filme "do cara de fora da favela" que viu os traficantes da favela e fez um filme sobre isso e que Tropa também foi "o cara de fora da favela" ${ }^{34}$ que viu a polícia e fez um filme sobre isso. Outro fato que sintetiza o estigma com as inúmeras representações ${ }^{35}$ da favela como espaço de violência ocorreu durante as oficinas de feitura do episódio Deixa voar. Quando os moradores integrantes da oficina elegeram o argumento que tinha como pano de fundo a divisão de uma região por ordem de facções rivais, metade do grupo desertou. "Foi preciso convencê-los a voltar, e alguns não voltaram. Os moradores das favelas querem que a gente saiba quem eles são, não querem mais saber das lendas urbanas sobre eles"36, contou Cacá Diegues.

Confluente à vontade de que os outros saibam quem eles são, Diegues escreveu uma longa carta aos sete diretores de $5 X$ favela - agora por nós mesmos. Nela, o cineasta cita as cinematografias do Terceiro Mundo como resistências ao grande mercado de Hollywood que ocupava todas as salas de cinema e as novas expressões do cinema independente que surgiram no seio das cinematografias centrais, "reagindo ao mercantilismo conservador dominante" e lembra que o auge desse processo coincidiu com "a explosão das novas tecnologias de captação e

\footnotetext{
${ }^{34}$ Disponível em <http://www.vermelho.org.br/noticia/133656-11>

35 "É importante ressaltar que paralelamente a este movimento de articulação cultural da periferia através da literatura temos observado a proliferação de obras literárias e fílmicas, não produzidas por sujeitos da periferia, que buscam examinar estes espaços marginalizados. A margem, este território quase esquecido e muitos vezes invisível da cidade, surge na contemporaneidade como um precioso território a ser explorado. Seja pelo olhar do próprio marginal, que agora abandona a posição de objeto para figurar como sujeito do próprio discurso, ou por autores não pertencentes à margem que, movidos pelo crescente interesse do mercado editorial, repetem as ideias e os preceitos formados pela Literatura Marginal, é inegável que a periferia urbana ocupa hoje, paradoxalmente, um espaço central na produção discursiva brasileira". In: PATROCÍNIO, Paulo Roberto Tonani de. Escritos à margem: a presença de autores de periferia na cena literária brasileira. Rio de Janeiro: 7Letras/Faperj, 2013. p19

${ }^{36}$ Disponível em <http://www.estadao.com.br/noticias/geral,cinco-episodios-lancam-novo-olharpara-as-favelas, $436895>$
} 
difusão do audiovisual, que deu a todos acesso à produção, multiplicou as telas e fragmentou de vez os públicos", acrescentando como causa da fragmentação do público a subdivisão dos gêneros e a pulverização de novos cinemas em diversos países. Na carta, Diegues afirma que os filmes hoje são mais reconhecidos "por seu nicho do que por sua nacionalidade" e que podem ser reconhecidos, ainda, pelas plataformas em que são alocados (salas multiplex, canais de televisão abertos ou fechados, DVD, Blue-Ray, vídeo-on-demand e downloads através do celular ou "qualquer outra coisa que apareça"). Assim, Diegues justifica a tentativa de criar uma linguagem para todos os espectadores, além de estabelecer estratégias diversas para que a voz periférica chegue a todos os públicos e plataformas. Nesse sentido, observamos a marca 5X Favela dando novos frutos e franquias, como o documentário $5 X$ Pacificação, em que os mesmos diretores buscam uma reflexão sobre a implantação das Unidades de Polícia Pacificadora (UPPs) nas comunidades e o livro $5 X$ favela, que narra histórias de bastidores, traz os diários dos diretores e revela os e-mails trocados entre Cacá e a equipe nos quais demonstra a clara intenção de reforçar que está passando o bastão aos novos narradores.

(...) Cada sociedade ainda tem uma economia formal de cinema que podemos chamar genericamente de sistema. O sistema, hoje, diante desse quadro que ainda se movimenta e se transforma, é uma espécie de estação onde se toma o trem para todas as plataformas. Só através dele você alcança, organizada ou organicamente, todos os meios de difusão disponíveis. Isso não significa que o que é feito fora dele não tenha valor, não deve existir ou simplesmente não seja capaz de emergir. (...) No Brasil, onde o sistema ainda não está consolidado como tal e permite invasões e intervenções para mudá-lo por dentro, vale a pena tentar subvertê-lo. Aqui, como no resto do mundo em geral, o que é feito fora do sistema não tem garantia de exposição. E o que não tem garantia de exposição acaba condenado aos festivais temáticos, aos cineclubes, às exibições domésticas. $\mathrm{O}$ que, aliás, não é nenhuma vergonha, claro!,essas manifestações já projetaram grandes filmes e revelaram excelentes cineastas. Mas aqui ainda podemos tentar fazer um cinema de valor estético, político e moral que, começando pelos multiplex (a vitrine natural de lançamento dos filmes), seja também difundido em todas as outras plataformas, da TV ao celular, do vídeo doméstico à internet. É essa a ambição de nosso projeto, como tenho dito sempre - preparar vocês para aquilo que chamo de um assalto ao sistema. No nosso caso, esse assalto viria de uma camada social e cultural excluída, de uma margem sem voz, que eu tenho certeza de que tem muito a dizer ao resto do País, tem muito oque propor pra fazer evoluir o nosso cinema e o próprio Brasil. (...) É preciso aprender a transformar o aparato em aparelho, pô-lo a nosso serviço e ao serviço de nossa imaginação e de nossas ideias. Essa é a única beleza do progresso, que não é nunca um valor em si mesmo. É nosso dever transformar o progresso em civilização. Dando esse passo à frente, conquistando isso, estaremos mais bem-preparados para o tal assalto ao 
sistema. Mas isso não quer dizer que se alguém preferir ficar fora desse esforço de conquista esteja errado. (...) de minha parte, repito minha profissão de fé de ontem. Nunca me contentei em ficar de fora, jogando pedras no "castelo do mal". Quero entrar na fortaleza, desarrumar o arrumado, para poder arrumar tudo de novo, ao alcance de todos, de um jeito que seja mais um humano, fraterno e generoso. Como acho que o cinema brasileiro é o próprio Brasil podem e devem vir a ser. ${ }^{37}$

Se a exposição das motivações de Diegues não afasta as questões levantadas inicialmente por nós - como o grau de inserção da alteridade como verdadeira narradora de suas próprias histórias, sua elaboração da forma estética do discurso em negociação com o mercado e a capacidade de "transformar o aparato em aparelho", além da clara noção de que existe um campo de batalha pela impressão do ponto de vista -, ela ao menos deixa entrever a tentativa do cineasta de alinhar a prática cinematográfica aos seus anseios como intelectual do Cinema Novo e à revisão crítica que faz sobre a representação do outro. Arriscando-nos a descontextualizar o complexo roteiro de Gayatri Spivak ${ }^{38}$ de que o subalterno não pode falar, quando leva em consideração a condição da mulher na Índia, gostaríamos de pensar na possibilidade de "elaborar estratégias de inclusão dessas subjetividades no próprio ato discursivo do intelectual" que o impeça de figurar "no lugar do discurso do Outro marginalizado" (PATROCÍNIO, 2013: 236). Levando-se em consideração a realista carta de Cacá Diegues sobre a nova modalidade de "assalto ao sistema" e a consciência de que ele próprio não inventou a roda, que já havia cinema quando ele chegou às comunidades para dar aula, gostaríamos de reivindicar a manutenção do cineasta-intelectual no papel daquele que continua tentando subverter a máquina, mas agora colocando-a também em favor de outros discursos. Permanece, no entanto, o desafio de superar as categorias estanques nós e eles, no sentido de fazer com que eles consigam sair da dependência do nós como legitimadores e difusores da voz.

\footnotetext{
${ }^{37}$ DIEGUES, Isabel; BARRETO, Paola (orgs.). 5 X favela-agora por nós mesmos. Rio de Janeiro: Cobogó, 2010.

${ }^{38}$ SPIVAK, GayatriChakravorty. Pode o subalterno falar? Belo Horizonte: Editora UFMG, 2010.
} 


\section{Conclusão}

Antes mesmo que o ano de 2015 chegasse à metade, o cinema brasileiro de ficção apresentou ao público dois filmes que podem ser tomados como pontos fora da curva - Branco sai, preto fica e Casa Grande. O primeiro, dirigido por Adirley Queirós, é uma produção que vem na onda do chamado "cinema de quebrada", termo definidor da produção audiovisual surgida na periferia dos centros urbanos. Mas, como salienta o crítico Luiz Carlos Merten, no jornal "O Estado de S.Paulo", onde o filme ganhou capa no suplemento cultural, a novidade, agora, é que um longa-metragem com esse perfil chegou ao espaço nobre nas salas de São Paulo - além de entrar no circuito de outras capitais. O crítico lembra, também, que as vozes da periferia só costumam aparecer com presença forte nas salas exibidoras depois de serem referendadas em festivais ou apadrinhadas por diretores famosos e distribuidoras grandes, diz Merten, citando como exemplo $5 X$ favela - agora por nós mesmos.

Há mais de dois meses em cartaz, o filme é produto de um coletivo de cinema na Ceilândia (Ceicine, em Brasília), que hoje agrega literatura, rap, questões de cidadania e movimentos sociais. Branco sai, preto ficaé uma exceção da regra no coletivo, que costuma produzir documentários. O diretor explicou que a opção pela ficção (científica) surgiu do impasse de remontar uma ação criminosa da polícia em Ceilândia, nos anos 1980, em que um dos integrantes do Ceicine perdeu a perna. Como havia resistência em reviver a tragédia com a abordagem documental, Marquim, vítima da violência policial, disse a Queirós que seria preferível se pudesse usar os recursos mágicos do cinema para voar, fazer aquilo que não consegue mais. "Chegamos à conclusão de que queríamos intervir na realidade criando uma ficção científica", contou o diretor a Luiz Carlos Merten.

Casa Grande, por sua vez, enquadra a classe média alta e traz já no título a crítica que alude ao clássico de Gilberto Freyre. Dirigido por Fellipe Barbosa, o longa-metragem também flerta com o documental - é parcialmente autobiográfico e trabalha com não-atores. $\mathrm{Na}$ trama, um adolescente, alterego do diretor, descobre que o patrimônio material de sua família está em ruínas, assim como os 
valores morais. Seus pais acumulam muitas dívidas, mas tentam manter as aparências e o status social (mansão, carros na garagem, empregados, restaurantes caros). Casa Grande vem sendo comparado a $O$ Som ao redor, de Kleber Mendonça Filho, por partir de um microcosmo de classe média alta, o condomínio, e reverberar nas relações dos mais abastados com o capital financeiro e com os empregados pertencentes às camadas sociais mais baixas. Em entrevistas para divulgar o filme, o diretor gosta de frisar que o período de filmagens coincidiu com a derrocada do bilionário Eike Batista e que a elaboração do roteiro ocorreu na mesma época em que o governo federal implantava as cotas raciais nas universidades, gerando a ira de parcela da elite. Fellipe Barbosa também não costuma esconder que sua história é um drama familiar, ainda que contemple as relações de classe no Brasil - e o título não deixa por menos. Ao jornal "Folha de S.Paulo", o diretor afirma que o subgênero sempre existiu, mas que a "nova tendência" talvez seja "o ponto de vista, que é o da classe média alta". "A nova geração está superdisponível para se colocar na tela".

Nesse sentido, Branco sai, preto fica e Casa Grande sintetizam algumas das questões que levantamos ao longo da tese. O primeiro se apresenta como uma das vozes da periferia, que chega ao grande circuito de salas sem apadrinhamentos e grande distribuidoras. Seu movimento em busca do público não se restringe aos seus pares, ao mesmo de classe (apesar disso, Queirós realiza, junto com o coletivo, mostras de cinema nas comunidades, para minorias sociais e culturais, colocando-as diante do espelho da representação. Esse tipo de produção sobre e da periferia e a difusão para a periferia está espalhado em muitos outros coletivos e vem sendo estudado atentamente por produtores culturais e na academia). A conquista do público de classe média, almejado pelo cinema de quebrada, suscita alguns dos debates que abordamos, como a negociação de uma estética intermediária entre o cânone e a margem, discutida na análise sobre o papel das oficinas e palestras aos profissionais oriundos das comunidades que dirigiram e trabalharam em $5 X$ favela - agora por nós mesmos. Como o enfoque da tese recaiu sobre o cinema que visa um público mais ampliado, nosso objetivo foi o de problematizar a busca por uma estética "autêntica" da margem, já que o mercado tem seus imperativos. Branco sai, preto fica, entretanto, encontrou uma alternativa interessante, lançando-se ao desafio de realocar o gênero de ficção científica dentro de uma produção audiovisual de poucos recursos. Já o remake de 
$5 X$ favela - agora por nós mesmos preferiu trilhar, desde sua pré-produção, o caminho do sucesso, celebrando, portanto, a união entre a periferia, o intelectual de classe média e os meios de produção. Oriundos das favelas cariocas, os sete diretores da refilmagem (Manaíra Carneiro, Wagner Novais, Rodrigo Felha, Cacau Amaral, Luciano Vidigal, Cadu Barcelos e Luciana Bezerra) continuam na ativa, sobrevivendo às leis da produção audiovisual.

Outro eixo que elegemos na tese, e que nos remete ao lançamento de Casa Grande, foi a sub-representação da classe média e das elites do país nas telas, em proporção diretamente inversa ao poder que ela tem de narrar. Em cotejo com as obras literárias que lhes deram origem, Abril despedaçado e A Hora da estrela, baseados em romances homônimos, extirparam da trama a autorreflexividade, que se materializava nos escritores Bessian Vorps e Rodrigo S.M., respectivamente. O primeiro, presente apenas no romance do albanês Ismail Kadaré, era acusado de vender livros e viver da fama, enquanto narrava com beleza a tragédia dos montanheses do norte da Albânia. Já o narrador do romance de Clarice Lispector interpelou o leitor para saber se palavras que soavam bem aos ouvidos eram realmente adequadas para contar a história de Macabéa, personagem que desconhecia o significa semântico da expressão ser feliz.

Nossa hipótese foi em direção a uma reconsideração do realismo de Suzana Amaral para dar abertura ao social. Para isso, nos apoiamos no texto em que Jacques Rancière tece considerações sobre o potencial político do romance realista do século XIX. Já o filme de Walter Salles inseriu um narrador intradiegético para contar a história ao lado do grande imagista do cinema (o diretor). Além de aproximar o narrador do narrado e do espectador (Pacu era o membro mais novo da família sobre a qual incide a tragédia), a função estratégica do menino foi a de intervir na vida do irmão. O gesto dos diretores parece se aproximar ao do intelectual pré-golpe militar e remete ao pessimismo da razão e o otimismo da vontade de Gramsci. Assim, Salles e Amaral deram a segunda chance aos seus protagonistas sem voz. Mudando o final das histórias, livraram seus personagens da morte (redenção como ideal, no caso de $A$ Hora da estrela, e como alternativa possível e real, no caso de Abril despedaçado).

As análises dos filmes Cidade de Deus, Tropa de elite e Carandiru problematizaram a posição do narrador. O primeiro, dirigido por Fernando Meirelles, ampliou o personagem Buscapé, alterego de Paulo Lins, autor do 
romance no qual o filme se baseou. Nossa tese foi a de que essa superrepresentação funcionou como o cartão de visita para que o grande narrador (Meirelles) e o espectador pudessem entrar na favela. Essa confortável visita do espectador ao espaço de alteridade - levando-se em conta que a classe média é a maior frequentadora das salas de cinema - foi possibilitada pela maneira sagaz com que Buscapé se adaptou ao asfalto. Sua vocalização para o grande público é límpida, sem gírias; sua arma não é o revólver dos bandidos da Cidade de Deus, mas uma câmera fotográfica em que retrata o outro (mesmo de Buscapé). Incoerente na forma e no conteúdo, o olhar de Buscapé é macro (vide a cena narrada por diversos ângulos, mas sempre com o mesmo resultado), quando esperávamos que seu ponto de vista e a narração em primeira pessoa fugissem das totalizações. Filme de favela, moda no cinema brasileiro, Cidade de Deus foi apontado pelos diretores de $5 X$ favela - agora por nós mesmos como contraexemplo de um olhar a ser lançado sobre as comunidades desassistidas pelo poder público.

Por outros motivos, o problema da narração voltou a se repetir em Carandiru, de Hector Babenco. O longa-metragem inseriu no Complexo Penitenciário de São Paulo um médico infectologista para recolher as histórias dos detentos. Na trama, porém, essas vozes jamais serão ouvidas sem a presença do cientista. É ele quem estimula o discurso e só através dele é que o espectador poderá assistir às imagens que remontam as histórias de vida dos presos fora daquele espaço panóptico. A opção por não dar um nome ao "doutor" reforça a abordagem cientificista entre o sujeito (o médico) e o objeto (detentos). Outro ponto que se questionou foi a maneira como a figura do médico foi minguando ao longo da história. Sua aparição constante no início do filme dá legitimidade ao grande narrador, funciona como muleta para que Babenco possa contar a história do Carandiru. Nesse sentido, inferimos que o personagem central estaria mascarando o discurso de terceira pessoa, que vem a ser o do diretor como grande encenador. A essas questões narrativas somam-se as críticas decorrentes da comparação da fíç̧ão com o documentário O Prisioneiro da grade de ferro, de Paulo Sacramento.

Por fim, tratamos da recepção de Tropa de elite, de José Padilha. Desdobramento ficcional de Rodrigo Pimentel, policial do BOPE no documentário Notícias de uma guerra particular, de João Moreira Salles, o longa- 
metragem, narrado em primeira pessoa pelo agente, se descolou do discurso do diretor. Nosso objetivo, com a análise de Tropa de elite, foi mostrar a cobrança da recepção do filme para que houvesse alguém capaz de segurar as rédeas do discurso do policial. Esse alguém seria o próprio diretor. Justifica-se daí as convocações da imprensa e da academia para que Padilha explicasse melhor suas intenções com Tropa de elite. Na década de 1970, Eduardo Coutinho realizou um movimento semelhante com o documentário Theodorico, o Imperador do sertão. Abandonando seu papel como mediador do discurso, Coutinho entregou como resultado um filme no qual a fala dominante, do latifundiário Theodorico, é repleta de preconceitos de classe e soberba. Curiosamente, Coutinho colheu elogios pela ousadia. Na literatura brasileira dos anos 1970, o exemplo se repete com o conto Feliz ano novo. Rubem Fonseca abandonou seu leitor de classe média nas mãos de narradores assaltantes, sem mediação que apaziguasse os ânimos ou que desse um final moral à história.

O que deve ficar patente em nossas análises dos filmes $A$ Hora da estrela, Abril despedaçado, Cidade de Deus, Tropa de elite, Carandiru e $5 X$ favelaagora por nós mesmos e nos capítulos anteriores é a necessidade de ascensão de novas vozes do discurso na produção cinematográfica. Porém, a sentença de André Malraux, para quem o cinema é arte, mas também é indústria, coloca em xeque a tentativa de buscar qualquer tipo de pureza nessas vozes, dado o sistema de produção audiovisual, sobretudo no que se refere aos complexos mecanismos de distribuição dos filmes nas salas de exibição. Levando-se em conta essas considerações sobre o meio, acreditamos na possibilidade de fazer o subalterno falar gradativamente em sua própria dicção. Para isso, dois movimentos orientados por um mesmo objetivo precisariam ser realizados: o primeiro consiste no reconhecimento, na reafirmação, da capacidade do intelectual de representar e falar pelo outro (pois a ficção consiste em se projetar sobre o outro, e Eduardo Galeano, citado na epígrafe dessa tese, nos diz que "o próximo é promessa, não é uma ameaça”), mas, sobretudo, na concessão da fala (nesse sentido, reconhecemos como louvável gestos como o de Cacá Diegues). O segundo movimento, acreditamos, é de ordem econômica, pois como afirmou Bernardet "a possibilidade de o outro de classe expressar-se está em relação direta com a propriedade dos meios de produção". A segunda epígrafe desse trabalho, do escritor Sérgio Sant'Anna corrobora a tese: "E haveria sempre alguém que 
pudesse narrar isso por ele, até que as condições socioeconômico-culturais da classe operária se transformassem no país e ela pudesse falar com a própria voz". 


\section{Referências bibliográficas}

ADORNO, Theodor. "Posição do narrador no romance contemporâneo". In: Notas de Literatura I. São Paulo: Duas Cidades; Ed. 34, 2003.

ALMENDRA, Dinaldo. Os mistérios do Carandiru. Rio de Janeiro: Editora Multifoco, 2011.

AUMONT, J. et al. A estética do filme. Campinas, SP: Papirus, 1995.

AUMONT, Jacques; MARIE, Michel. Dicionário teórico e crítico de cinema. Campinas, SP: Papirus, 2003.

O ponto de vista. In: Eduardo Geada (org.). Estéticas do cinema. Lisboa: Dom Quixote, 1983.

. As teorias dos cineastas. Campinas, SP: Papirus, 2004.

O cinema e a encenação. Lisboa: Edições Texto \& Grafia, 2008.

AVELLAR, José Carlos. O cinema dilacerado. Rio de Janeiro: Alhambra, 1986. . O chão da palavra: cinema e literatura no Brasil. Rio de Janeiro: Rocco, 2007.

AZEVEDO, Reinaldo. Capitão Nascimento bate no Bonde do Foucault. Revista Veja, n. 2030, 17 out. 2007.

BAKHTIN, Mikhail. Problemas da poética de Dostoievski. Rio de Janeiro: Forense-Universitária, 1981.

BAZIN, André. O que é o cinema? São Paulo: Cosac Naify, 2014.

BERNARDET, Jean-Claude. Brasil em tempo de cinema: ensaio sobre o cinema brasileiro de 1958 a 1966. São Paulo: Companhia das Letras, 2007.

Cinema. In: NOVAES, Adauto (org.). Anos 70: ainda sob a tempestade. Rio de Janeiro: Aeroplano: Editora Senac Rio, 2005.

Cineastas e imagens do povo. São Paulo: Companhia das Letras, 2003.

. Historiografia clássica do cinema brasileiro. São Paulo: Annablume, 2004.

. GALVÃO, Maria Rita. O nacional e o popular na cultura brasileira: cinema. São Paulo: Brasiliense, 1983.

Trajetória crítica. São Paulo: Editora Polis, 1978.

. O atrevido provocador. Entrevista concedida a Maria do Rosário Caetano. Revista de Cinema, 2003. Disponível em: $<$ http://www.scribd.com/doc/6543578/JeanClaude-Bernardet-OAtrevidoProvocador> Acesso em: $20 \mathrm{dez} .2013$.

BOBBIO, Norberto. Os Intelectuais e o poder. São Paulo: Ed. da UNESP, 1997.

BOSCOV, Isabela. Abaixo a mitologia da bandidagem. Revista Veja, n. 2030, 17 out 2007.

BORDWELL, David. O cinema clássico hollywoodiano: normas e princípios narrativos. In: RAMOS, Fernão Pessoa (org.). Teoria contemporânea do cinema. Vol. 2. São Paulo: Editora Senac, 2005.

BOURDIEU, Pierre. As regras da arte: gênese e estrutura do campo literário. São Paulo: Companhia das Letras, 1996.

BROWNE, Nick. O plano-ponto-de-vista. In: RAMOS, Fernão Pessoa (org.). Teoria contemporânea do cinema. Vol. 2. São Paulo: Editora Senac, 2005.

BUTCHER, Pedro. Cinema brasileiro hoje. São Paulo: Publifolha, 2005. 
BUTCHER, Pedro; MÜLlER, Anna Luiza. Abril Despedaçado: história de um filme. São Paulo: Companhia das Letras, 2002.

CANDIDO, Antonio. Literatura e sociedade. São Paulo: Nacional, 1965.

CARNEIRO, Marcelo. A realidade, só a realidade. Revista Veja, n. 2030, 17 out. 2007.

CARVALHO, Bernardo. O mundo fora dos eixos. São Paulo: Publifolha, 2005.

CARVALHO, Maria do Socorro. Cinema novo brasileiro. In: MASCARELLO, Fernando. História do cinema mundial. Campinas, SP: Papirus, 2006.

CHAUÍ, Marilena. Intelectual engajado: uma figura em extinção? In: NOVAES, Adauto (org). O Silêncio dos intelectuais. São Paulo: Companhia das Letras, 2006.

COUTINHO, Eduardo. Eduardo Coutinho fala de seu trabalho. Disponível em: $<\mathrm{http}: / /$ www.mnemocine.com.br/aruanda/coutinhoav.htm $>$ Acesso em: 20 set. 2014. Entrevista.

COUTO, José Geraldo. Cidade de Deus questiona produção nacional. In: NESTROVSKI, Arthur (org.). Em branco e preto: artes brasileiras na Folha, 1990-2003. São Paulo: Publifolha, 2004.

DA-RIN, Silvio. Espelho partido: tradição e transformação do documentário. Rio de Janeiro: Azougue editorial, 2006.

DIEGUES, Isabel; BARRETO, Paola (orgs.). 5 X favela - agora por nós mesmos. Rio de Janeiro: Cobogó, 2010.

EAGLETON, Terry. Teoria da literatura: uma introdução. São Paulo: Martins Fontes, 2001.

EDUARDO, Cléber. "Eu é um outro" - Variações da narração em primeira pessoa. In: CAETANO, Daniel (org). Cinema Brasileiro: 1995 - 2005: ensaios sobre uma década. Rio de Janeiro: Azougue Editorial, 2005.

. Diretores transnacionais latino-americanos (1985-2007). In: BAPTISTA, Mauro; MASCARELLO, Fernando (org.). Cinema mundial contemporâneo. Campinas, SP: Papirus, 2008.

FIGUEIREDO, Vera Lúcia Follain de. Da profecia ao labirinto: imagens da história na ficção latino-americana contemporânea. Rio de Janeiro: Imago, UERJ, 1994.

. Exílios e diásporas. In: GOMES, Renato Cordeiro; MARGATO, Izabel. O Papel do intelectual hoje. Belo Horizonte: UFMG, 2004.

. Os crimes do texto: Rubem Fonseca e a ficção contemporânea. Belo Horizonte: UFMG, 2003.

. Realismo e ilusão: a cruzada contra o artifício. XVI Compós. Curitiba, PR, 2007. Disponível em $<$ http://www.compos.org.br/data/biblioteca_206.pdf $>$ Acesso em: 20 set 2009.

. Realismo e novos estatutos da ficção. In: MARGATO, Izabel; GOMES, Renato Cordeiro. Realismos: objetos, escritas, efeitos. Belo Horizonte: UFMG, 2009.

. Narrativas migrantes: literatura, roteiro e cinema. Rio de Janeiro: Ed. PUC-Rio: 7Letras, 2010.

FONSECA, Rubem. Feliz ano novo: contos. São Paulo: Companhia das Letras, FOUCAULT, Michel. Microfísica do poder. Rio de Janeiro: Graal, 1979. . A ordem do discurso. São Paulo: Edições Loyola, 2007.

História da sexualidade I: a vontade de saber. Rio de Janeiro: Graal, 1988. 
FREITAS, Guilherme. A defesa Coetzee. Jornal O Globo, Rio de Janeiro, 13 abr. 2013. Prosa, p.2.

GAUDREAULT, André; JOST, François. A narrativa cinematográfica. Brasília: Editora UnB, 2009.

GENETTE, Gérard. Discurso da narrativa: ensaio de método. Lisboa: Arcádia, 1979.

GERBER, Raquel et al. Glauber Rocha. Rio de Janeiro: Paz e Terra, 1977. HOLLANDA, Heloísa Buarque, VENTURA, Zuenir. 70/80 Cultura em trânsito: da repressão à abertura. Rio de Janeiro: Aeroplano, 2000.

HOLANDA, Karla. Documentário brasileiro contemporâneo e a micro-história. Revista de História e Estudos Culturais, v. 3, ano 3, n. 1, jan/fev/mar 2006.Disponível em: <www.revistafenix.pro.br> Acesso em: 15 dez. 2008.

KADARÉ, Ismail. Abril despedaçado. São Paulo: Companhia das Letras, 2001. Dossiê H. São Paulo: Companhia das Letras, 2001.

LEITE, Ligia Chiappini Moraes Leite. O foco narrativo. São Paulo: Editora Ática, 1987.

LINS, Consuelo. O documentário de Eduardo Coutinho: televisão, cinema e vídeo. Rio de Janeiro: Jorge Zahar, 2004.

LINS, Consuelo; MESQUITA, Cláudia. Filmar o real: sobre o documentário brasileiro contemporâneo. Rio de Janeiro: Jorge Zahar Ed., 2008.

LINS, Paulo. Cidade de Deus. São Paulo: Companhia das Letras, 1997. . Cidade de Deus. São Paulo: Companhia das Letras, 2002.

LISPECTOR, Clarice. A hora da estrela. Rio de Janeiro: Nova fronteira, 1977.

MACHADO, Arlindo. O sujeito na tela: modos de enunciação no cinema e no ciberespaço. São Paulo: Paulus, 2007.

MAGNY, Joël. Cahiers du Cinéma. Le point de vue: Du regard du cinéaste à la visión du spectateur. Paris: Cahiers du Cinéma, 2001.

MARTIN, Marcel. A linguagem cinematográfica. São Paulo: Brasiliense, 2007.

MEIRELLES, Fernando; PADILHA, José. "Tropa de Elite tem mais impacto do que Glauber Rocha”. Revista Bravo. São Paulo, janeiro de 2008. Entrevista.

MORAES, Dênis de (org.). Combates e utopias: os intelectuais num mundo em crise. Rio de Janeiro: Record, 2004.

MORENO, Antonio. Cinema brasileiro: história e relações com o estado. Niterói: EDUFF; Goiânia: CEGRAF/UFG, 1994.

MULVEY, Laura. Prazer visual e cinema narrativo. In: XAVIER, Ismail (org.). A experiência do cinema. Rio de Janeiro: Graal, 1983.

NAGIB, Lúcia. A utopia no cinema brasileiro: matrizes, nostalgia, distopias. São Paulo: Cosac Naify, 2006.

NEVES, David. A descoberta da espontaneidade (Breve Histórico do CinemaDireto no Brasil). In: COSTA, Flávio Moreira da (org.). Cinema Moderno Cinema Novo. Rio de Janeiro: José Álvaro Editor, 1966.

NICHOLS, Bill. Introdução ao documentário. Campinas, SP: Papirus, 2005. - A voz do documentário. RAMOS, Fernão Pessoa (org.). Teoria contemporânea do cinema, vol. II. São Paulo: Editora Senac São Paulo,2005b.

NOGUEIRA, Cyntia Araújo. Anos 90, anos 60: a crítica cinematográfica brasileira "pós-retomada" e a tradição moderna. Dissertação de mestrado em Comunicação UFF, Niterói: 2006.

OLIVEIRA, Augusto Cesar Freitas de. O filme do ano: observações periféricas 
sobre Tropa de Elite. Revista achegas.net, n. 38, mai.ago. 2008. Disponível em: <http://www.achegas.net/numero/38/augusto_38.pdf $>$ Acesso em: 20 set. 2008.

OLIVEIRA, Francisco de. No silêncio do pensamento único: intelectuais, marxismo e política no Brasil. In: NOVAES, Adauto (org). O Silêncio dos intelectuais. São Paulo: Companhia das Letras, 2006.

ORICCHIO, Luiz Zanin. Cinema de novo: um balanço crítico da retomada. São Paulo: Estação Liberdade, 2003.

PADILHA, José. Sabatina Folha. Folha de S. Paulo. 31 out 2007. Entrevista. Disponível em: $<$ http://www1.folha.uol.com.br/fsp/cotidian/ff3110200735.htm> Acesso em: 20 mai. 2011.

PATROCÍNIO, Paulo Roberto Tonani do. Escritos à margem: a presença de autores de periferia na cena literária brasileira. Rio de Janeiro: 7Letras/Faperj, 2013.

RAMOS, Alcides Freire. Canibalismo dos fracos: cinema e história no Brasil. Bauru, SP: EDUSC, 2002.

RAMOS, Fernão Pessoa. Mas afinal... o que é mesmo documentário? São Paulo: Editora Senac São Paulo, 2008.

RAMOS, José Mário Ortiz. Cinema, Estado e lutas culturais: anos 50, 60, 70. Rio de Janeiro: Paz e Terra, 1983.

RANCIÈRE, Jacques. $O$ efeito de realidade e a política da ficção. Novos estudos - CEBRAP [online]. 2010, n.86, pp. 75-80. ISSN 0101-3300.

RIBEIRO, Paulo Jorge. Cidade de Deus na zona de contato - alguns impasses da crítica cultural contemporânea. Revista de crítica literária latinoamericana. $\mathrm{N}^{\circ}$ 57. Lima-Hanover, $\mathrm{NH}$; 1er. Semestre de 2003, pp. 125-139.

RIDENTI, Marcelo. Em busca do povo brasileiro: artistas da revolução, do CPC à era da tv. Rio de Janeiro: Record, 2000.

ROCHA, Glauber. Manifesto Uma estética da fome. In: http://tropicalia.uol.com.br/site/internas/leituras_gg_cinenovo.php, publicado originalmente na Revista Civilização Brasileira, $n^{\circ} 3$, julho de 1965.

. Revolução do Cinema Novo. São Paulo: Cosac Naify, 2004.

. Patrulhas Ideológicas (1980). In: GASPARI, E., HOLLANDA, H.B., VENTURA, Z. 70/80 Cultura em trânsito: da repressão à abertura. Rio de Janeiro: Aeroplano, 2000. Entrevista.

RODRIGUES, Nelson. Crítica de Terra em transe. Correio da Manhã, 16 mai. $1967 . \quad$ Disponível em: $<$ http://tempoglauber.com.br/glauber/Filmografia/terra.htm> Acesso em: 17 mai. 2008.

ROUANET, Sérgio Paulo. As razões do iluminismo. São Paulo: Companhia das Letras, 1987.

- A crise dos universais. In: NOVAES, Adauto (org). O Silêncio dos Intelectuais. São Paulo: Companhia das Letras, 2006.

SALLES, Walter. Entrevista concedida à revista Continente, em 01/4/2002.

Disponível em

$<$ http://www.revistacontinente.com.br/index.php/component/content/articl e/64-cinema/669-walter-salles-entrevista.html $>$

SANT'ANNA, André. Rush. In: FREIRE, Marcelino; OLIVEIRA, Nelson de 
(orgs.).

SANT'ANNA, Sérgio. Um discurso sobre o método. In: MORICONI, Ítalo. Os Cem melhores contos brasileiros do século. Rio de Janeiro: Objetiva, 2000.

SANTIAGO, Silviano. Nas malhas da letra. São Paulo: Companhia das Letras, 1989.

SARLO, Beatriz. Cenas da vida pós-moderna: intelectuais, arte e vídeocultura na Argentina. Rio de Janeiro: UFRJ, 2004.

Tempo passado: cultura da memória e guinada subjetiva. São Paulo: Companhia das Letras; Belo Horizonte: UFMG, 2007.

SARMIENTO, Guilherme. Homens sem sombra - uma tendência intelectual em tempos recentes. IN: CAETANO, Daniel (org.). Cinema brasileiro 19952005: ensaios sobre uma década. Rio de Janeiro: Azougue editorial, 2005.

SARTRE, Jean-Paul. Em defesa dos intelectuais. São Paulo: Ática, 1994.

SCHWARZ, Roberto. Sequências brasileiras. São Paulo: Companhia das Letras, 1999.

. Cultura e Política. São Paulo: Paz e Terra, 2005.

SIMONARD, Pedro. Origens do Cinema Novo: a cultura política dos anos 50 até 1964. Revista achegas.net, n. 9, jul. 2003. Disponível em: $<$ http://www.achegas.net/numero/nove/pedro_simonard_09.htm> Acesso em: 20 abr. 2012.

SPIVAK, Gayatri Chakravorty. Pode o subalterno falar? Belo Horizonte: Editora UFMG, 2010.

STAM, Robert; SHOHAT, Ella. Crítica da imagem eurocêntrica. São Paulo: Cosac Naify, 2006.

STAM, Robert. Introdução à teoria do cinema. Campinas, SP: Papirus, 2003.

. O espetáculo interrompido: literatura e cinema de desmistificação. Rio de Janeiro: Paz e Terra, 1981.

. A literatura através do cinema: realismo, magia e a arte da adaptação. Belo Horizonte: UFMG, 2008.

Multiculturalismo tropical: uma história comparativa da raça na cultura e no cinema brasileiros. São Paulo: Edusp, 2008b.

TELLA, Andrés Di. "O documentário e eu". In: MOURÃO, Maria Dora; LABAKI, Amir (orgs.). Cinema do real. São Paulo: Cosac Naify, 2005.

VIANY, Alex. O processo do Cinema Novo. AVELLAR, José Carlos (org.). Rio de Janeiro: Aeroplano, 1999.

WOLFF, Francis. Dilemas dos intelectuais. In: NOVAES, Adauto (org). O Silêncio dos intelectuais. São Paulo: Companhia das Letras, 2006.

XAVIER, Ismail. O cinema brasileiro dos anos 90. In: Praga, estudos marxistas, São Paulo, v. 9, pp. 97-138, 2000.

. O discurso cinematográfico: a opacidade e a transparência. São Paulo: Paz e Terra, 2005.

- O olhar e a cena: melodrama, Hollywood, Cinema Novo, Nelson Rodrigues. São Paulo: Cosac Naify, 2003.

. Cinema Brasileiro Moderno. São Paulo: Paz e Terra, 2001.

. Sertão Mar: Glauber Rocha e a estética da fome. São Paulo: Cosac Naify, 2007.

. Encontros: Ismail Xavier. MENDES, Adilson (org.). Rio de Janeiro: Azougue, 2009. 
. Humanizadores do inevitável. In: ALCEU (Revista do programa de pósgraduação da PUC-Rio): Rio de Janeiro: Editora PUC, V.8, $N^{\circ} 15$, jul./dez. 2007.

- Corrosão social, pragmatismo e ressentimento: vozes dissonantes no cinema brasileiro de resultados. Novos Estudos, 75. Julho 2006. 